\title{
Do You Want to Know a Trade Secret? How Article 2B Will Make Licensing Trade Secrets Easier (But Innovation More Difficult)
}

\author{
Rochelle Cooper Dreyfuss $\dagger$
}

\section{TABLE of Contents}

Introduction

I. Article 2B and the Trade Secrets Industries.............................200

A. Distinctions Created by Article 2B ...................................200

1. License vs. Sale of a Copy ............................................203

2. Information vs. Informational Content.............................206

B. An Analysis of Article 2B's Substantive Provisions...............209

1. General Provisions.........................................................209

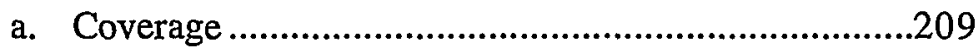

b. Choices of Law and Forum.......................................212

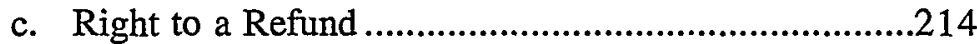

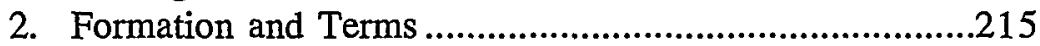

a. Article 2B's Statute of Frauds....................................215

b. Article 2B's Article 2-207 Analogue ........................217

c. Other Methods of Formation ...................................219

d. Mass Market Contracts.........................................220

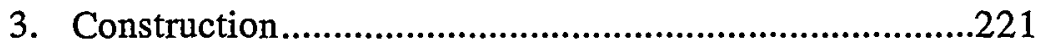

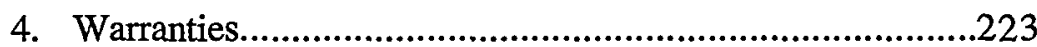

a. Implied Warranties...................................................224

b. Affirmative Warranties...........................................224

c. Express Warranties and "Beta Models"....................225

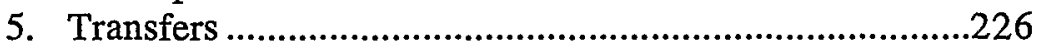

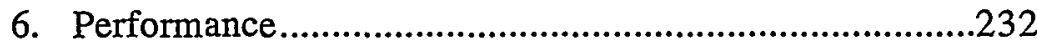

Copyright 1999 California Law Review, Inc.

$\dagger$ Professor of Law and Director of the Engclberg Center on Innovation Law and Policy, New York Univcrsity Law School. The author owes a great debt of gratitude to Mark Lemley, who not only roped me into thinking about this issue, but also read an earlier draft with a great deal of care. I also want to thank Chuck Knapp and Helen Scott for helping me remember Article 2, Ronald Abramson and George A. Cooke, Jr. for giving me helpful insights from practice, and the Filomen D'Agostino and Max E. Greenberg Research Fund for its financial support. Keith Buell, NYU Law School Class of 2000 , has been an invaluable assistant. 


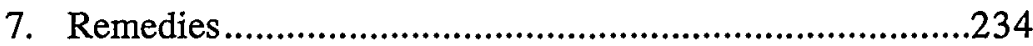

a. Article 2B Remedies Generally ..............................234

b. Article 2B's Trade Secret Remedies Specifically.......235

i. Monetary Damages.............................................235

ii. Specific Performance........................................236

iii. Liquidated Damages...........................................237

II. Article 2B and National Innovation Policy: Article 2B's

Intersection with Federal and State Law and Policy ....................238

A. Article 2B and Federal Law and Policy ................................238

1. The Secrecy Approach ..................................................240

a. Tensions Between the "Secrecy Approach" and Federal Innovation Policy ...........................................240

b. Tensions Between the "Secrecy Approach" and Federal Intellectual Property Law..............................246

2. The "Rights Distinction"...........................................249

B. Article 2B and State Law and Policy ...................................253

1. Article 2B's Intersection with State Law Generally ..........254

2. Article 2B's Intersection with State Laws and

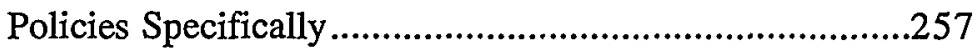

C. A Reasoned Perspective .....................................................259

D. Suggested Improvements to Article $2 B$..............................262

1. Clarify the Relationship Between Article 2B and

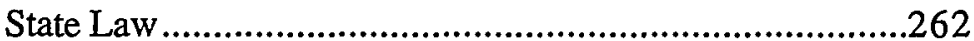

2. Endorse Blue Penciling....................................................263

3. Take Limited Times Seriously .....................................264

4. Consider the Baseline.................................................264

5. Reconsider Digital and Like Environments ....................266

6. Piggyback on the Federal Trade Commission ...................266 


\title{
Do You Want to Know a Trade Secret? How Article 2B Will Make Licensing Trade Secrets Easier (But Innovation More Difficult)
}

\author{
Rochelle Cooper Dreyfuss
}

Proposed U.C.C. Article 2B's coverage of trade secrets is welcome in many ways. Article $2 B$ recognizes the special characteristics of intangibles, such as the difficulty of inspecting delivery, monitoring use, and effectively returning information. For trade secrets, which are state-lawbased, nationally uniform licensing rules are especially desirable; they will surely lead to a reduction in the risk of disclosure. Article $2 B$ does not, however, fully account for the differences between copyrights and trade secrets. For example, the remedies provisions do not treat losses created by disclosure; the formation provisions do not consider the impact of licensing on the patentability of the technologies licensed. Moreover, reducing the risk of disclosure could conflict in a fundamental way with national innovation policy, which is premised on information leakage. To the extent Article $2 B$ stops secrets from reaching the domain of the public, it inhibits creative production.

This Article is in two parts. The first examines how the specific provisions of Article $2 B$ affect trade secrets. The second both analyzes the interaction between Article $2 B$, intellectual property law, and innovation policy and suggests ways to improve Article $2 B$.

Listen, do you want to know a secret, Do you promise not to tell, whoa oh, oh. ${ }^{1}$

\section{INTRODUCTION}

It is certainly a heady time for trade secrecy law. Fifteen years ago, this was strictly a common law area. To the extent that there was quasilegislative direction, it was found in the first Restatement of Torts. ${ }^{2}$ There

1. The Beatles, Do You Want to Know a Secret, on Introducing the Beatres (Vee-Jay Records 1963).

2. RESTATEMENT OF TORTS $\S \S 757-59$ (1939). 
was, of course, a certain irony there: a document completed by the American Law Institute (ALI) in 1934, long superseded with respect to ordinary civil wrongs, ${ }^{3}$ remained in place for trade secrecy-the one branch of tort law directly concerned with innovation. And when the National Conference of Commissioners on Uniform State Laws (NCCUSL) promulgated the Uniform Trade Secrets Act (UTSA) as a modern legislative approach to trade secrecy law in 1982, states were slow to sign on. By 1985, when NCCUSL amended the UTSA, only nine states had adopted it.

We are now in a very different world. In 1995, in a document (surprisingly) entitled the Restatement (Third) of Unfair Competition, ${ }^{5}$ the ALI finally reconsidered trade secrecy law. By then, however, restating the common law was soinewhat irrelevant to a majority of jurisdictions, because they had already enacted the UTSA. Around the same time, trade secrecy law also acquired three quintessential signs of jurisprudential recognition: criminalization, federalization, and internationalization. The Economic Espionage Act of $1996^{6}$ turned misappropriation into a federal crime, while the 1994 Agreement on Trade Related Aspects of Intellectual Property Rights (the TRIPS Agreement) required every member of the General Agreement on Tariffs and Trade (GATT) to protect undisclosed information. ${ }^{7}$

Now another body of trade secrecy law is being proposed. A joint effort of the ALI and NCCUSL, Article 2B of the Uniform Commercial Code (U.C.C.) covers "transactions in information." Although this document is mainly directed at protecting copyrighted material and devising licensing rules for the electronic environment, its coverage is broad enough to encompass transactions involving trade secrets: the document defines "informational rights" to include "all rights in

3. See RESTATEMENT (SECOND) OF TORTS (1965). A third Restatement is now in the drafting.

4. UNIF. Trade Secrets ACT (amended 1985), 14 U.L.A. 437 (1990).

5. RESTATEMENT (THIRD) OF UNFAIR COMPETITION (1995).

6. 18 U.S.C.A. $\$ \S 1831-39$ (West Supp. 1998). I analyze this statute in a forthcoming article. See Rochelle Cooper Dreyfuss, Trade Secrets: How Well Should We Be Allowed to Hide Them? The Economic Espionage Act of 1996, FordhaM INTELL. PROP. MEDIA \& ENT. L.J. (forthcoining).

7. See General Agreement on Tariffs and Trade: Multilateral Trade Negotiations Final Act Embodying the Results of the Uruguay Round of Multilateral Trade Negotiations, Apr. 15, 1994, Annex 1C: Agreement on Trade-Related Aspects of Intellectual Property Rights, art. 39, 33 I.L.M. 1197.

8. U.C.C. art. 2B Prefatory Note at 1 (Annual Meeting Draft, July 24-31, 1998). [All versions of Article 2B are available on the Internet. See National Conference of Commissioners on Uniform State Laws, Drafts of Uniform and Model Acts Official Site (last modified Sept. 2, 1998) <http:// www.law.upenn.edu/library/ulc/ulc.htm $>$. The Official Site offers the Article 2B drafts in several file formats, among which the pagination is inconsistent. In this Article and throughout this issue of the California Law Review, page references are to the pages as they are numbered in the Acrobat PDF file format. Only the prefaces to the drafts are cited by page number; all other material is cited by section number. The draft of August 1, 1998, has no page numbers in its on-line versions, and therefore the preface of that draft is cited without page references. $E d$. 
information created under laws governing ... trade secrets ... or any other law that permits a person, independently of contract, to control or preclude another person's use of the information on the basis of the rights holder's interest in the information." Article 2B, when coupled with the increased codification and recognition of trade secrecy law, will enable trade secret holders to exploit their rights fully with the assurance of truly comprehensive protection.

For innovation law in general, Article $2 \mathrm{~B}$ is an important development. As its Prefatory Note observes, Article $2 B$ "concerns transactions that largely have never been covered by the UCC": those pertaining to the distribution of intangible products. ${ }^{10}$ Although courts have occasionally applied Article 2 of the U.C.C. to these transactions, it has proved inapposite. Its focus on sales does not comport with the licensing tradition prevalent in many of the intellectual property industries. Moreover, at a conceptual level, analogizing intellectual property rights to rights in goods does not work at all. Because information is intangible, Article 2's focus on issues such as the inspection and delivery of physical product leads to rules that neither reflect the understanding of the parties nor further their legitimate interests.

Federal law has also failed at times. Copyright and patent laws protect only products with a high level of creativity. Yet there are commercially important works that are not very creative, but still costly to develop. Because many of these works are often easy to copy and distribute, the inadequate protection that federal law affords against free riders is not a small matter. As the Supreme Court has sometimes recognized, state laws protecting intellectual property serve as an important adjunct to federal intellectual property law, "encourag[ing] invention in areas where patent law does not reach, and [prompting] the independent innovator to proceed with the discovery and exploitation of his invention." A A properly attuned state system is therefore fundamental to motivating the optimum level of creation and dissemination of products that are sure to be keys to wealth and welfare in the next century.

Before celebrating Article 2B, however, the intellectual property community should scrutinize it with care. Indeed, Article $2 B$ has already attracted significant interest from the copyright bar. Major pieces by two copyright scholars, Raymond Nimmer, the reporter of Article 2B, and David Rice, a meinber of the Drafting Committee, have made that sector very aware of how the document will affect its practice. ${ }^{12}$

9. Id. § 2B-102(27).

10. Id. art. 2B Prefatory Note at 2.

11. Kewanee Oil Co. v. Bicron Corp., 416 U.S. 470, 485 (1974).

12. See, e.g., Raymond T. Nimmer, UCC Revisions: Information Age in Contracts, in 17TH Annual Institute on Computer law 377 (PLI Pats., Copyrights, Trademarks \& Literary Prop. Course Handbook Series No. G-471, 1997), available in Westlaw, PLI database, 471 PLI/Pat 377 
Significantly less attention has been paid to Article 2B's effect on the trade secrecy community. ${ }^{13}$ This Article takes on that effort. In so doing, it addresses essentially two sets of issues: (1) Article 2B's success as a set of default rules for contracting in the information industries; and (2) the interaction between Article $2 \mathrm{~B}$ and federal law.

First addressed is the issue of how well Article $2 \mathrm{~B}$ achieves its stated goal of creating a set of default contracting rules in the information industry. As in other sections of the U.C.C., Article 2B allocates risk, sets warranties, and determines remedies. While these provisions are intended to set out a series of background rules-basically, default positionsand parties are generally free (with particularized exceptions) to negotiate around them, ${ }^{14}$ negotiation is costly. It is therefore important that these rules reflect basic expectations. The Drafting Committee was, of course, well-suited to make these determinations. It included noted practitioners and scholars, and it regularly consulted with a wide range of organizations and, of course, with its sponsors, the ALI and NCCUSL. ${ }^{15}$

However, much of the Drafting Committee's deliberations occurred before trade secrets formally entered the mix of matters that Article 2B would cover. That is, when the idea of expanding Article 2 arose in 1992, the plan was to deal with a very specific set of problems: transactions involving digital products, particularly software, and especially with regard to exploitation in an on-line environment. That focus was later generalized to cover other intangibles, first copyrighted materials, and later the "information industry." However, by the time that the concept of comprehensive treatment crystallized in July $1995,{ }^{16}$ a great deal of the drafting had already taken place, and the group appointed to deal with the more general task saw itself as "further develop[ing] the structure and rules in which so much previous effort had been invested."17

Now, there are certainly commonalities between "pure" copyright industries and industries where trade secrecy is an important avenue of

[hereinafter Nimmer, UCC Revisions]; Raymond T. Nimmer, Federal Preemption in Intellectual Property Law, in PLI's Second ANNuAd Institute For INTEllectual Property LaW 95 (PLI Pats., Copyrights, Trademarks \& Literary Prop. Course Handbook Series No. G-453, 1996), available in Westlaw, PLI database, 453 PLI/Pat 95 [hereinafter Nimmer, Federal Preemption in Intellectual Property Law]; David A. Rice, Digital Information as Property and Product: U.C.C. Article 2B, 22 U. DAYTON L. REv. 621 (I997).

13. But see Mark A. Lemley, Intellectual Property and Shrinkwrap Licenses, 68 S. CAL. L REv. 1239 (1995).

14. See U.C.C. art. 2B Prefatory Note at 13-14, §§ 2B-106(a), 2B-107(a) (Annual Meeting Draft, July 24-31, 1998).

15. See id. art. 2B Prefatory Note at 6-8.

16. See id. art. 2B Prefatory Note at 7; see also Rice, supra note 12, at 627-28.

17. Rice, supra note 12 , at $627-28$. 
protection. Indeed, because computer programs are often protected by both copyright and trade secrecy, there was certainly some consideration of trade secrecy from the imception of the project. At the same time, there are also differences in outlook and practice, especially with regard to the non-copyright sector of the industries that utilize trade secrecy protection. It is not entirely clear that the drafters, the organizations they consulted, or the sponsoring institutions had the flexibility to work all such differences into the draft at the point in the drafting process when the scope of Article 2B expanded. ${ }^{18}$ In this regard, it is significant that the Drafting Committee ultimately decided to exclude expressly the licensing of patents and trademarks from the ambit of the Article. The stated rationale was that these licenses "entail[] many different assumptions and standard practices."19 Since many of the same mdustries that rely on patent protection also utilize trade secrecy, it is likely that if there are mismatches between Article 2B and the assumptions of the patent industries, there will be similar mismatches on the trade secrecy side. ${ }^{20}$ In fact, the possibility that Article $2 \mathrm{~B}$ meshes poorly with expectations in the trade secrecy fleld (or, with expectations in the field outside the computer program sector) is underscored by the fact that the draft text and accompanying reporter's notes contain many more references to patent licenses than to trade secrecy situations. ${ }^{21}$

18. Thus, the Preface to the draft of November 1, 1997, U.C.C. art. 2B Preface at 7 (Draft, Nov. 1, 1997), listed over thirty organizations that reviewed interim drafts. Many of these organizations are in the copyright industries; fewer are in the technology sector. Several of the organizations listed are bar associations, but it is not clear which committees in these associations commented on the draft. For example, the Association of the Bar of the City of New York is listed. As a nember of that Association, I know that the Coinputer Committee commented on the draft; the Patent Committee, whicl has many of the lawyers that deal in trade secrecy licensing, did not. Similarly, it would be interesting to know how many people on the AL1's Consultive Group were drawn from the technology sector.

19. U.C.C. § 2B-104(a)(2), 2B-104 reporter's note 3 (Annual Meeting Draft, July 24-31, 1998); see also id. \$ 2B-103 reporter's note 3(c). Article 2B also contains soine exclusions relevant to trade secrets, which are discussed in the text infra accompanying notes 56-68. Despite these exclusions, Article $2 \mathrm{~B}$ is clearly meant to cover trade secrets generally, and not merely those embedded in software. See id. \$ 2B-102(27), 2B-102 reporter's note 7.

20. It is worth identifying mismatches with patent industry assunptions for several reasons. Article 2B will certainly be applied to software patents, see id. $\S 2 \mathrm{~B}-103$ (a)(1), and it is likely to be applied to other patents as well. Thus, the drafters have often spoken of Article $2 B$ as useful by analogy. See, e.g., U.C.C. art. 2B Preface at 15, § 2B-103 reporter's note 5(b) (Draft, Nov. 1, 1997). Although the analogy language was removed from the current draft, patent examples and references to patent situations were not. More important, Article 2B will apply to those aspects of licenses that involve covered subject matter, even if they also cover patents. It is thus likely to have spillover effects in patent licensing cases. It may also forge a new understanding of the relationship between contract law and innovation policy, especially in state courts, which at present are relatively unfamiliar with federal intellectual property law. See infra note 26.

21. Althougl the large number of patent examples in earlier drafts of Article $2 B$ shows that the drafters were influenced by patent law, the drafters have since removed most of these examples. Thus, coinpare the draft of May 5, 1997, which has patent examples at U.C.C. §§ 2B-102 reporter's note 16, 2B-106 reporter's note 3, 2B-201 reporter's note 7, 2B-306 reporter's note 2, 2B-310 
The second issue this Article addresses is whether the drafted provisions adequately accommodate federal law and national policy. Article 2B differs from federal patent and copyright regimes in a crucial way. Whereas the federal regimes focus on both the exploitation of information products (in that they work to assure an adequate return on investment in creativity) as well as the creation of information products (in that they allow creators to build on the works of others), Article $2 \mathrm{~B}$ deals only with the issue of information exploitation. Although the provisions attempt to accommodate federal patent and copyright rules, ${ }^{22}$ their concentration on exploitation leads to a somewhat cavalier dismissal of creative issues. ${ }^{23}$ As a result, Article $2 \mathrm{~B}$ could have two very different, and conflicting, impacts on the creative environment. On the one hand, it imposes, or at least facilitates the imposition of, licensing restrictions that could have the salutary effect of providing new mechanisms for encouraging innovation. On the other hand, Article $2 \mathrm{~B}$ could well frustrate innovation by undermining a core premise of federal innovation policy, namely, that information leaks: That is, knowledge flows inevitably into the domain of the public, where innovators can use what others have learned and improve upon what they have done. ${ }^{24}$

Courts hearing Article $2 B$ cases will face an unenviable situation. They will have to draw difficult lines against the backdrop of federal preemption doctrine, the contours of which are poorly defined. ${ }^{25}$ They will entertain these challenges on a case-by-case basis, where the cumulative effects of Article $2 \mathrm{~B}$ will not be easy to discern. To make matters worse, the courts most often called upon to decide these issues will be state courts, which are largely unfamiliar with federal intellectual

reporter's note 4, 2B-311 reporter's note 2, 2B-401 reporter's notes 5-6 \& illus. 1, 2B-501 reporter's note $1,2 \mathrm{~B}-502$ reporter's notes 4-5, 2B-507 reporter's note 5, 2B-508 reporter's note $2,2 \mathrm{~B}-708$ reporter's note 10 (Draft, May 5, 1997), with the draft for the Annual Meeting of July 24-31, 1998, which contains many references excluding patent licensing from the scope of Article $2 \mathrm{~B}$, see, e.g., U.C.C. art. 2B Prefatory Note at 9, §§ 2B-103 reporter's note 3(c), 2B-104 reporter's note 3, 2B-401 reporter's note 1 (Annual Meeting Draft, July 24-31, 1998), but nevertheless includes several examples of patent licensing, see id. Prefatory Note at 8, \$§ 2B-102 reporter's note 26, 2B-308 reporter's note 2, 2B-501 reporter's note 1, 2B-507 reporter's note 2 . The draft for the Annual Meeting of July 24-31, 1998 also makes many references to interactions between Article $2 B$ and patent law. See id. §§ 2B-102 reporter's note 11, 2B-103 reporter's note 2(d), 2B-105 reporter's notes 3-4, 2B-208 reporter's note $6,2 \mathrm{~B}-506$ reporter's note $4,2 \mathrm{~B}-507$ reporter's notes 2-3, 2B-702 reporter's note 4 .

22. See, e.g., U.C.C. art. 2B Prefatory Note at 15-17 (Annual Meeting Draft, July 24-31, 1998).

23. See, e.g., id. art. 2B Prefatory Note at 12 (discussing the "political and social role" of information, but not the role that information has in producing new information). The tendency to ignore creative issues is especially clear in earlier drafts. See, e.g., U.C.C. art. 2B Preface at 21 (Draft, Nov. 1, 1997) (dismissing "upstream" issues).

24. See infra Part II.A (discussing Kewanee Oil Co. v. Bicron Oil Corp., 416 U.S. 470 (1974), and related cases).

25. See infra text accompanying notes $222-232$. 
property policy. ${ }^{26}$ And while Article $2 \mathrm{~B}$ repeatedly states that federal policy always controls in the event of a conflict, ${ }^{27}$ the drafters have not chosen to provide any guidance for inaking these difficult determinations.

The draft's positions on state law and state policies are even harder to fathom. Article 2B cites the ALI's Restatement (Third) of Unfair Competition exactly once, ${ }^{28}$ and NCCUSL's other work on trade secrets, the UTSA, not at all, even though both documents are an important source of state innovation policy. Further, state cases dealing with trade secrecy $^{29}$ and covenants not to coinpete ${ }^{30}$ articulate important innovation policies, but go unmentioned in Article 2B. Article 2B's failure to grapple meaningfully with these policies raises questions about the extent to which states that enact Article $2 \mathrm{~B}$ are repealing contrary policies sub silentio (perhaps in the name of achieving uniformity). ${ }^{31}$

26. Trade secrecy is a matter of state law, so claims are generally heard in state fora, uniess they are part of a larger federal case and fall within the federal court's supplemental jurisdiction, see 28 U.S.C. $\$ 1367$ (1994), or unless the parties to the dispute are of diverse citizenship and choose federal adjudication under 28 U.S.C. $\$ 1332$. Copyright and patent claims fall within the exclusive jurisdiction of the federal courts, see id. $\$ 1338$, unless they are styled as breach of contract actions. See, e.g., Lear, Inc. v. Adkins, 395 U.S. 653 (1969). Article 2B may alter the distribution of cases at the margin because of its choice of forum provision. See U.C.C. § 2B-108 (Annual Meeting Draft, July 24-31, 1998); infra text accoinpanying note 88.

Article 2B also raises significant antitrust and First Amendment problems. However, state courts are likely to be more familiar with the issues, because states have their own antitrust laws and state courts hear First Amendment cases. For the drafters' consideration of these issues, see, e.g., U.C.C. art. 2B Prefatory Note at 15, \$ 2B-105 reporter's note 5 (Annual Meeting Draft, July 24-31, 1998) (antitrust law), and id. art. 2B Prefatory Note at 9, \$ 2B-102 reporter's note 32 (First Amendment).

27. See id. art. 2B Prefatory Note at 7, §§ 2B-105 \& reporter's notes, 2B-208 reporter's notes 4(b) and 6.

28. See id. \$ 2B-105 reporter's note 3 .

29. See, e.g., Wexler v. Greenberg, 160 A.2d 430 (Pa. 1960).

30. There is both statutory and case law on eovenants not to compete. See, e.g., CAL. Bus. \& Prof. CoDE $§ 16600$ (Deering 1993); McLeod v. Meyer, 372 S.W.2d 220 (Ark. 1963); Solari Indus., Inc. v. Malady, 264 A.2d 53 (N.J. 1970); Dionne v. Southeast Foam Converting \& Packaging, Inc., 397 S.E.2d 110 (Va. 1990). For a detailed analysis of both state and criminal law on these issues, see Eli Lederman, Criminal Liability for Breach of Confidential Commercial Information, 38 EMORY LJ. 921 (1989).

31. Reporter's note 5 to section 104 states that

[m]any contracts governed as to contract law principles by Article 2B are also governed by other state statutes, regulations and common law principles. In nost instances, the other legal principles are parallel or deal with different subject matter than Article $2 \mathrm{~B}$ or the U.C.C. generally. This is especially true with respect to regulatory rules that mandate soine conduct in a specific imdustry or market. These mandatory rules coexist with contract law since, as in Article 2B, the contract law focuses on general formation principles and background rules that are subject to contrary agreeinent or mandate. Of course, when the common law does conflict with Article 2B, the later-enacted, uniform statutory treatment of the UCC (Article 2B) controls.

U.C.C. \$ 2B-105 reporter's note 5 (Annual Meeting Draft, July 24-31, 1998). The same note also provides that "state law concerning trade secrecy is preserved and may affect the terms of contracts otherwise within Article 2B." Id. 
This Article has two Parts, reflecting the two areas where I have identified a need for further scrutiny. Part I addresses the first set of issues mentioned above, namely, how Article $2 \mathrm{~B}$ affects existing state trade secrecy doctrine and industry practice. Part II deals with the interplay between Article $2 \mathrm{~B}$ and national innovation policy and concludes with some recommendations for improvement.

Readers should note that this Article is addressed to the Annual Meeting Draft submitted to NCCUSL at its July 24-31, 1998 meeting. Since that timie, significant changes have been made. But one must stop sometime. Many of the comments herein are directed at the approach rather than at the specifics; those that are directed at superseded specifics will, I hope, shed light on the legislative history, and hence on the final product.

\section{I}

\section{Article 2B ANd the Trade Secrets Industries}

Article $2 B$ 's drafters strove to duplicate for the information industries the predictable contracting environment that those who deal in goods have long enjoyed under Article 2. As with Article 2, the main work of Article 2B is formulating default rules to govern dispute resolution in the absence of contractual agreement. ${ }^{32}$ Another goal is to protect specific parties in situations where an asymmetry in knowledge or bargaining power can lead to overreaching. ${ }^{33}$

In this Part, I analyze Article 2B's success in meeting these goals. Because Article 2B crafts, and depends on, a set of distinctions that did not exist in prior law, the success of the overall enterprise is a function of three factors: (1) the extent to which the created distinctions reflect genuine characteristics of the economic sectors affected by Article 2B; (2) the degree to which these distinctions map intellectual property law; and (3) the match between each rule and the positions to which the parties would have likely bargained. After analyzing Article 2B's newly crafted distmctions in this next Section I.A., in Section I.B. I turn to a part-by-part analysis of its substantive provisions, discussing their relationship with existing trade secrecy doctrine and specific provisions of federal intellectual property law.

\section{A. Distinctions Created by Article $2 B$}

It is in the nature of new laws to draw fresh lines between familiar concepts. Article $2 \mathrm{~B}$ is no exception to this rule. It sets up at least six distinctions that differ from anything found in Article 2. These are the

32. See id. art. 2B Prefatory Note at $\mathbf{1 4 .}$

33. See id. art. 2B Prefatory Note at $\mathbf{1 5 .}$ 
distinctions between (1) electronic and physical distribution; (2) mass market and other transactions; (3) information submissions and tender; (4) material breach, nonmaterial breach, and default; (5) licenses and sales of copies; and (6) information and informational content. ${ }^{34}$

The first four distinctions require little elaboration, while the last two merit greater attention. The first distinction-electronic/physical distribution - is very important to Article $2 \mathrm{~B}$, because the drafters intended to create rules for the on-line environment, where delivery of "product" can be fraught with difficulties that do not arise when goods are exchanged physically. In this environment, there are no "writings," a "signature" is a click of a mouse, and there is no way to verify who is doing the clicking. ${ }^{35}$ By focusing specifically on this situation, the drafters were able to generate a new set of terms, such as "record," "authentication," "attribution procedure," and "electronic agent," and a new set of rules that adapt intellectual property licensing to cyberspace. These rules inay very well be controversial. They will also be important to those trade secrecy lawyers whose clients distribute their products electronically. However, because these concepts could cover all on-line transactions, including banking and the sale of goods, the concerns they raise are ultimately shared by everyone who intends to do business in cyberspace..$^{36}$ Since they are not particular to trade secrecy, I do not discuss then further.

The next set of distinctions is of importance to the trade secrecy community, but should prove uncontroversial, or at least not especially so for trade secrecy industries. Accordingly, I shall discuss it only briefly in this Article.

Like the physical/electronic distinction, the mass market concept also derives from one of the project's early goals: making law for computer program licensing. ${ }^{37}$ In the computer licensing sector, the consumer/commercial dichotomy used in Article 2 worked poorly because in the conuputer market, many commercial enterprises act like ordinary consumers: they buy off the shelf (i.e., in the nuass market) for end-use, with no possibility of individualized negotiation and little expertise in the technology underlying the product they are purchasing. By creating the "mass market" category, and providing special protection to everyone who purchases works in the nuass inarket, whether they fit Article 2B's definition of consumer or not, the drafters claim that

34. I address a seventh distinction on which the drafters rely heavily, rights against individuals versus rights against the world, in Part II infra. See text accompanying notes 272-293.

35. See U.C.C. art. 2B Prefatory Note at 17, §§ 2B-102 reporter's note 3, 2B-105 reporter's note 8 (Annual Meeting Draft, July 24-31, 1998).

36. Indeed, there has been talk of generalizing these rules to Article 2 generally, or to the U.C.C. as a whole. See id. art. 2B Prefatory Note at 17.

37. See id. art. 2B Prefatory Note at 5-6. 
Article $2 \mathrm{~B}$ will give to such purchasers the same level of protection that Article 2 provides to consumers. ${ }^{38}$

While the mass market concept and the physical/electronic distinction were developed to standardize law for computer program licensing, the distinctions between information submissions and tender ${ }^{39}$ and between material breach, nonmaterial breach, and default $t^{40}$ differ in origins. They are not related to the goals of Article 2B, but are instead necessary to account for disparities between tangibles and intangibles. These disparities make the concepts surrounding acceptance and rejection in Article 2 inappropriate to Article $2 \mathrm{~B}$. That is, the malleability of intangible works means that there are times when little significance needs to attach to the nonconformity of a delivery: since the parties expect that the final product will be a joint product of creator and user, the term "submission" better reflects what goes on in these transactions. At the same time, the nature of intellectual products is such that the significance that Article 2 attaches to rejection is misplaced. Knowledge flows irreversibly; a secret once learned cannot be unlearned. Accordingly, the nature of breach and the remedies applicable in the case of a breach cannot simply mimic those that apply to transactions in goods, where a complete unambiguous return can be accomplished. ${ }^{41}$

Those distinctions to one side, that leaves two distinctions to discuss here: that between a license and the sale of a copy ${ }^{42}$ and the distinction between information and informational content. ${ }^{43}$ These dichotomies create problems both for intellectual property doctrine in general and for trade secrecy law in particular.

38. See id. $\S \S 2 \mathrm{~B}-102$ reporter's note 28, 2B-208; see also U.C.C. art. 2B Preface at 17-20 (Draft, Nov. 1, 1997). For the most part, trade secret licenses are not mass marketed; instead, licenses are negotiated, usually by sophisticated parties. While it is true that many consumer products contain trade secrets, consumers do not generally put the secrets to any use other than the one that is authorized. There may be purchasers, however, who do not buy for consumer use, but rather to learn the technology through reverse engineering. See infra text accompanying note 235 (discussing Sega Enterprises, Ltd. v. Accolade, Inc., 977 F.2d 1510 (9th Cir. 1992)). This Article focuses on the enforcement of restrictions in mass market licenses as it relates to those who wish to utilize the technology for non-consumer purposes, but not as it relates to the protection of consumers. For a general discussion of the Uniform Commercial Code and consumer protections, see Gail Hillebrand, The Uniform Commercial Code Drafting Process: Will Articles 2, 2B, and 9 Be Fair to Consumers?, 75 WASH. U. LQ. 69 (1997).

39. See U.C.C. $\S 2 B-603$ reporter's note 1 (Annual Meeting Draft, July 24-31, 1998).

40. See, e.g., id. $\$ \$ 2 \mathrm{~B}-109,2 \mathrm{~B}-610,2 \mathrm{~B}-614$.

41. As the text infra accompanying notes $90-93$ shows, this distinction is not fully carried forward through Article 2B.

42. See U.C.C. art. 2B Prefatory Note at 10, § 2B-103 reporter's note 2(a) (Annual Meeting Draft, July 24-31, 1998).

43. See id. $\$ \S 2 B-102(24),(26),(27),(28), 2 B-102$ reporter's notes $22,23,25,26$. Prior drafts incorporated rights in a work into the concept of the work. See e.g., U.C.C. $\$ 2 B-102$ (22) (Draft, Nov. 1, 1997). The 1998 Annual Meeting Draft has corrected this problem by defining a third term: “informational rights." U.C.C. § 2B-102 (27) (Annual Meeting Draft, July 24-31, 1998). 


\section{License vs. Sale of a Copy}

Section 2B-103 sets out the scope of Article 2B as covering licenses and software contracts. ${ }^{44}$ Reporter's note $2(\mathrm{c})$ reads:

Licenses. Article 2B applies to licenses. A "license" is a contract for conditional rights, privileges, or permissions to use information, an information processing resource, or an informational property right. A license exists only if the contract expressly conditions the rights or permissions conveyed or expressly grants less than all rights in the information. Section 2B-102. Except for computer software, this Article thus does not deal with unrestricted sale of copies of information even though sales of copies are subject to restrictions under copyright or patent law. ${ }^{45}$

Thus, except with respect to computer software, Article 2B does not deal with unrestricted sales of copies of information, such as books and newspapers. ${ }^{46}$ The reasoning is that in an unrestricted sale of a copy, the information provider does not contractually condition use. Instead, it authorizes sale, and relies on copyright or other law to restrict use of the information in the copy. Implied conditions, which are often present because of copyright law, do not in themselves place the transaction within the scope of Article 2B. In contrast, the key facet of a license is that the contract inposes express limits on the use of the information. Because the transaction focuses on intangibles rather than goods, a license can and often does coexist with a transfer that constitutes a sale of a copy of the licensed subject matter.

Because Article 2B governs licensing, the license/sale distinction is obviously important for the entire statutory scheine. Unfortunately, note 2 (c) raises several important issues. First, why is software excluded? The current draft provides virtually no explanation. However, a note to the March 10, 1998, Draft states that this was done because all sales of software are, in fact, subject to restrictions on use, distribution, or modification. ${ }^{47}$ Since these restrictions make sales of software the functional

44. See U.C.C. \$ 2B-103 (Annual Meeting Draft, July 24-31, 1998). This section, on the scope of Article 2B, has been one of its most contested provisions. At the May, 1998 meeting of the American Law Institute, the drafting committee agreed to give the scope issue plenary reconsideration. See note preceding text of $i d$. $\$ 2$ B-103. The draft for the Annual Meeting of July 24-31,1998 (on which this Article is based) is, thus, hopefully not the final word. In addition to the comments made in the text, it is worth noting that the provision is ambiguous. Subsection 2B-103(a)(1) talks of "any transaction that creates a software contract, access contract, or license." It is not clear whether "software" modifies only "contract," or whether it is meant to modify the entire phrase. Although the latter reading would dramatically change the reach of Article 2B, it would be responsive to a motion made (and later withdrawn) by Stephen Y. Chow at the ALI meeting. Nonetheless, the apparent meaning of $\$ 2 B-103$ is as stated in the text: Article $2 B$ applies to all licenses in the information industries. See id. $\S 2 \mathrm{~B}-103$ reporter's note 1.

45. Id. $\$ 2 \mathrm{~B}-103$ reporter's note 2 (c) (einphasis added).

46. See id. $\$ 2 \mathrm{~B}-103$ reporter's note 1 .

47. See id. \$ 2B-103 reporter's note 3(a). 
equivalent of licenses, Article 2B's definition of "license" allows for equivalent treatment of all software dealings, no matter how the transaction is labeled ${ }^{48}$ The problem with this explanation is that much the same can be said about any information product covered by a copyright or patent.

Consider, for example, the operation of the first-sale doctrine. Under both copyright law and patent law, a sale releases a physical object (let us say a book) into the hands of the public. The intellectual property right (the copyright on the work) cannot be enforced upon subsequent sale ${ }^{49}$ As a result, public access to the work is increased (members of the public who want to read the book but cannot afford to pay the copyright holder's price can buy used copies for much less). At the same time, however, the interests of the holder of the intellectual property right are safeguarded because possession of the physical object (the book) remains subject to significant restraints. Unless authorized, the owner of the physical object cannot make other copies (by, for example, photocopying the book), nor can she distribute other copies or create derivative works (such as write a screenplay of the story). Similarly, the owner of an embodiment of a patented technology (say, a toaster containing a patented shut off mechanism) can resell the embodiment (the toaster), but cannot, without the patentee's permission, reconstruct the embodinient (build a new toaster with the same shut off mechanism), redeploy the technology in another embodiment or make an improvement (e.g., build a coffee maker that utilizes the patented shut-off mechanism). The net effect, then, of the first-sale doctrine is to make sales of the physical embodiments of all protected material akin to licenses. Recognizing the functional equivalence of sales and licenses only with respect to software calls into question the status of sales of copies in these other contexts. Admittedly, Article 2B emphasizes that the implied restrictions imposed by copyright and patent law remain in force..$^{50}$ Nonetheless, this treatment creates confusion and, as others have noted, may invite intellectual property holders to restructure their business dealings as licenses in a way that undermines aspects of the first-sale doctrine and inay frustrate its public-regarding aspects. ${ }^{51}$

In a way, this problem is a syinptom of a larger concern, which is Article 2B's disregard for the way that intellectual property lawyers usually formulate the sale/license divide. Instead of labeling the transaction, they consider what it is that is being transferred; the doctrine is thus

48. See id.

49. See 17 U.S.C. $\$ 109$ (a) (1994) (copyright law); Adams v. Burke, 84 U.S. (17 Wall.) 453 (1873) (patent law). The same is also true of trademarked products. See Prestonettes, Inc. v. Coty, 264 U.S. 359 (1924).

50. See, e.g., U.C.C. art. 2B Prefatory Note at 15 (Annual Meeting Draft,-July 24-31, 1998).

51. See Rice, supra note 12, at 544; see also infra text accompanying notes 258-260. 
formulated in terms of a "work" and a "copy" (or an invention and its embodiment). Section 202 of the Copyright Act puts it this way:

Ownership of a copyright, or of any of the exclusive rights under a copyright, is distinct from ownership of any material object in which the work is embodied. Transfer of ownership of any material object, including the copy or phonorecord in which a work is first fixed, does not of itself convey any rights in the copyrighted work embodied in the object; nor, in the absence of an agreement, does transfer of ownership of a copyright or of any exclusive rights under a copyright convey property rights in any inaterial object..$^{52}$

Accordingly, the principle of reporter's note 2(c) of section 2B-103 of the 1998 Annual Meeting Draft could have been expressed more easily: Article 2B deals mainly with transactions in works, not copies. Since Article 2B does, in fact, state a rule similar to section 202 of the Copyright Act, ${ }^{53}$ it would have been relatively simple to employ terminology with which intellectual property lawyers are familiar. Of course, it might then have been more difficult to effectuate the coverage that the U.C.C. gives to copies, but use of the traditional language would have allowed the drafters to treat software like other works.

The use of the traditional intellectual property dichotomy would have also had another and inuch more crucial effect: it would have highlighted that intellectual property law is not just about transacting, but also about creating "works." Given the purpose of intellectual property law to motivate creativity with the promise of economic benefits, suppressing the concept of the "work" is of monumental importance. Ignoring the concept means that the drafters can also ignore the justification for recogmizing these rights in the first place. Now, it is true that as Article 2B currently stands, it conforms with Article 2, which likewise disregards the rationale for recogmizing rights in goods. But this formal similarity misses an important difference. Rights in goods do not need much justification because possession of tangibles is rivalrous. Since inultiple owners would clearly interfere with each other's possessory interests, exclusivity is needed to assure the highest and best use of tangible property. Absent special circumstances, such as antitrust or First Amendinent concerns, these rights tend to be plenary. In contrast, multiple ownership of intellectual property is possible and, in fact, enhances social welfare. As a result, exclusive rights in information require explanation and necessarily carry limitations. Suppressing the

52. 17 U.S.C. $\$ 202$ (1994). Section 101 of the Copyright Act drives the point home. It defines "copies" and "phonorecords" as "material objects." Id. $\S 101$. The creative material embodied is called a "work" or a "sound recording." Id.

53. See U.C.C. § 2B-501(b) (Annual Meeting Draft, July 24-31, 1998). 
concept of the "work," or promoting the formal similarity between goods and intellectual products, veils the need for these limitations.

To put this another way, the rationale for creating exclusive rights in intellectual products does not go quite as far as the rationale for private ownership of goods. The reason is that the knowledge base is cumulative; progress depends on innovators building upon the work of those who came before. If the legal regime is set up in a manner that allows an early producer to use his right in a way that inhibits those who wish to follow, the goals underlying the regine are compromised. Moreover, since there is only so much economic motivation that any one creator needs, not every utilization of intellectual property needs to be put in the creator's control. ${ }^{54}$

This difference between goods and intellectual products means that Article 2B cannot simply adopt Article 2's aggressive policy of party autonomy. ${ }^{55}$ Parties could too easily contract in ways that upset the balance that intellectual property law creates, and thereby undermine the goal of fostering creativity. And although the drafters repeatedly acknowledge that intellectual property policy (as well as antitrust law and the First Amendment) puts limits on contracting, suppressing the concept of the "work" will most certainly influence how courts (especially state courts) interpreting Article $2 \mathrm{~B}$ will perceive the issues, and may decrease their commitment to protecting the capacity of society to produce new works. As we shall see, formulating this distinction in this way also affects the ability of Article $2 \mathrm{~B}$ to grapple with certain of the difficult issues that it was drafted to resolve.

\section{Information vs. Informational Content}

Article 2B's distinctions between information and informational content will also take intellectual property lawyers some time to get used to. Although this distinction seems intended mainly to preserve expectations in the publishing industry and to accommodate First Amendment values, ${ }^{56}$ it inay give rise to unintended consequences. Thus, subsections 2B-102(24) and (26) distinguish between information and informational content. Subsection (24) defines information as "data, text, miages, sounds, inask works, or works of authorship. " subsection (26) singles out-presumably for special treatmentthose aspects of works that can be apprehended from a superficial

54. This, in fact, is the logic of the first-sale doctrine discussed above: it manifests fcderal law's attempt to balance the creator's interest in capturing a reward against the public's interest in access by providing the creator with one, but only one, chance to sell each embodiment of the work.

55. See, e.g., U.C.C. art. 2B Prefatory Note at 12-13, § 2B-106 reporter's note 1 (Annual Meeting Draft, July 24-31, 1998).

56. See id. art. 2B Prefatory Note at 13; see also id. §§ 2B-402 reporter's note 4, 2B-404(b)(2).

57. Id. § 2B-102(24). 
examination of their physical embodiments. This provision states that "'[i]nformational content" means information that is intended to be communicated to or perceived by an individual in the ordinary use of the information, or the equivalent thereof." ${ }^{38}$ Subsection (24) tracks the language of section 102(a) of the Copyright Act, which illustrates the kinds of works that the Copyright Act protects; ${ }^{59}$ the drafters' willingness to use this formulation once again calls into question their decision generally to suppress the idea of a "work."

Putting that question to one side, however, the problem with the information/informational content distinction is that it may alter a core divide of trade secrecy law. Trade secrecy law differs from federal intellectual property regimes in an inportant way. Instead of relying on a specific term of protection as a way to balance the rights of creators against the access needs of the public, the term ends when the secret is disclosed. This principle is expressed in two ways. First, rights attach only to information that is valuable because it is secret; once information becomes generally known, every nember of the public has the right to utilize it. $^{60}$ Second, rights run only against "n1isappropriation." Since misappropriation does not include reverse engineermg, anyone who can figure out creative content from studying publicly distributed embodiments of that content has a free right to use the information. Now, Article $2 \mathrm{~B}$ 's dichotomy does not eliminate disclosure as a technique for balancing interests. It does, however, appear to move the line between what is considered public and what is secret: Information that is perceived in ordinary use is public, but everything else is apparently now considered secret, including information that can be learned by thoroughly studying embodiments. Article 2B's use of the word "confidential" reinforces that effect, since the term refers to information on which there is a duty of confidentiality, irrespective of whether the information is actually secret. Because duties of confidentiality are enforceable, Article $2 \mathrm{~B}$ (again) has the effect of reducing

58. Id. $\$ 2 \mathrm{~B}-102(26)$. This recent draft includes an important change over earlier versions of Article $2 \mathrm{~B}$ in that this definition goes on to state that " $\mathrm{t}] \mathrm{he}$ term does not include instructions used solely to control the interaction of a coinputer program with other computer programs or with a inachine." Id. The significance of this language is discussed later. See infra text accompanying note 240.

59. See 17 U.S.C. \& 102(a) (1994).

60. See Restatement (ThIRD) OF Unfair Competition \$ 39 (1995); Unif. Trade Secrets AcT $\$ 1(4)$ (amended 1985), 14 U.L.A. 438 (1990). Technically, under the Uniform Trade Secrets Act, information loses its protection as soon as reasonable efforts to protect its confidentiality are suspended. See id. § 1(4)(iii) (providing that only information subject to efforts to maintain secrecy are "trade secrets").

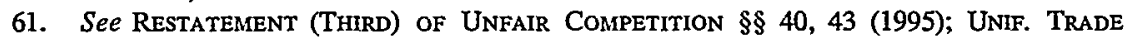
SECRETS ACT \$§ 1(1), (2) (amended 1985), 14 U.L.A. 437-38 (1990). 
the utility of disclosure as a way of balancing public and private interests. $^{62}$

More generally, the information/informational content distinction-indeed, its entire terminology - is based on an artificial construct. The fact is, what is perceived depends on how hard the perceiver is looking. The icons in Word Perfect 8.0, for example, are certainly "informational content" because they can be perceived when the program is loaded. Are the descriptions of the icons "informational content"? They can be perceived if the mouse lingers on them, but the ordinary user does not need to linger. And how about aspects of the program that computer buffs may wish to see in order to perfect their working environment, but which the rest of us would just as soon ignore? Finally, how about the program code, which can probably be listed by true cognoscenti? The dichotomy between that which is, and is not, immediately perceived may have some significance in deciding when liability should attach to an information provider for First Amendment purposes-although even here, it is difficult to see why the drafters could not have simply distinguished between published and nonpublished information. ${ }^{63}$ But the distinction is elusive for other purposes, and even seems to have confused the drafters themselves. ${ }^{64}$

Fimally, the focus on perception makes it seem as if all Article 2B subject matter has an independent existence, exogenous to Article 2B itself, as if "information" and "informational content" have a locus in the real world, just as the goods sold under Article 2 do. With respect to federal intellectual property rights, that is more or less true, because the defining feature of the "goods" (federal law) is external to Article 2B. Trade secrets are different, however. In many instances, they are creatures of the contract-that is, but for the promise of confidentiality entered into at the time the knowledge was transferred, there would be no "right" that could be licensed because there would be no

62. See, e.g., U.C.C. §§ 2B-105 reporter's note 3, 2B-202(e), 2B-309, 2B-707(b) (Annual Meeting Draft, July 24-31, 1998). Subsection 2B-707(b) refers to both trade secrets and information on which there is a duty of confidentiality. Currently, courts do not generally enforce claims on the use of information that is generally known, even if the defendant had agreed to keep it confidential. Cf. Softel Ine. v. Dragon Med. \& Scientific Communications, Inc., 118 F.3d 955, 968 (2d Cir. 1997) (inquiring into the novelty of the information allegedly subject to trade secrecy protection). There may, of course, be a claim for breaching the duty of confidentiality, but if the information was known anyway, the relief could be de minimis.

63. See U.C.C. $\S \S 2 B-404$ (b)(2), 2B-409(a), 2B-707(d)(1) (Annual Meeting Draft, July 24-31, 1998).

64. See, e.g., id. § 2B-604. The reporter's note recognizes that knowledge has a special characteristic - it cannot always be easily returned - by suspending the application of rights to refuse and inspect when the licensee has received substantial benefit from delivery. The notc, however, talks of benefit from the informational content, even though the recipient could equally receive benefit from information that is not intended to be perceived by reverse-engineering the product. 
information that was valuable by virtue of being secret. ${ }^{65}$ Article $2 \mathrm{~B}$ elides this problem. As I argue below, this makes it difficult to interpret some of its provisions, ${ }^{66}$ and obscures the relationship between Article $2 \mathrm{~B}$ and national innovation policy. ${ }^{67}$

\section{B. An Analysis of Article 2B's Substantive Provisions}

I now turn to a part-by-part analysis of Article 2B's substantive provisions, focusing on the effects (intended or not) that they may have on trade secrecy law. On the whole, the drafters of Article 2B regard its provisions as desirable default positions. I will analyze them on that basis. In a few instances, the drafters claim that particular rules are required by federal law. Although overall consistency with national policy is deferred to the next Part of this Article, ${ }^{68}$ these specific claims are analyzed here.

\section{General Provisions}

Many of the general provisions of Article 2B are directed at finding electronic analogues for the physical details involved in classical contract formation, such as signatures and writings. As with several of the distimctions discussed above, these rules may affect trade secrecy law, but not in a unique way. Soine of these general rules, however, will have specific effects on the trade secrecy industries. They include: the rules governing coverage, choice of law and forum, and the right to a refund.

\section{a. Coverage}

The coverage, or scope, provisions have been annong the most highly contested features of Article 2B. As noted in the introduction, the project itself has changed over time and the scope provisions have reflected these changes. As of this writing, the enterprise has entered a narrowing phase, with the result that the three sections on coverage2B-103, 2B-104, and 2B-105-now contain many carve-outs. These are of two types: (1) some exempt specific creative sectors; (2) others circumscribe Article 2B's applicability in light of other law.

65. Moreover, there would be nothing to show that reasonable efforts were made to keep the information confidential. See RESTATEMENT (THIRD) OF UNFAIR COMPETITION $\$ \$ 41$ (confidentiality agreements), 42 (employment agreements) (1995); UNIF. TRADE SECRETS ACT $\S$ 1(4), 14 U.L.A. 438 (1990) (trade secrets). See generally Robert G. Bone, A New Look at Trade Secret Law: Doctrine in Search of Justification, 86 CALIF. L. REv. 241, 251-61 (1998) (arguing that trade secrecy is just a collection of legal norms, often deriving from contract principles).

66. For example, it may become difficult to determine when einployment-related trade secrets are excluded from coverage under sections $2 \mathrm{~B}-104(2)$ and (5). See U.C.C. $\$ 2$ B-104 reporter's note 6 (Annual Meeting Draft, July 24-31, 1998). It is also hard to decide what law is at issue in section 2B-107's choice of law provision. See infra text accompanying notes 68-88.

67. See infra Part II.

68. See infra Section II.A, in Part II. 
The sector-based provisions are designed to exempt from coverage those industries that are heavily regulated by other law or by "longestablished contracting practices." ${ }^{\circ 9}$ For trade secrets, the most important of these exemptions are subsections 2B-104(2) and (5). Section 2B-104(2) provides that Article 2B does not cover those aspects of an agreement that involve "a trademark, trade name, trade dress, patent, or related know-how not associated with a license or software contract that is otherwise covered by this article." ${ }^{10}$ Since many trade secrets are discovered in conjunction with a patented technology, they may be considered "related know-how." If If so, this limitation could remove a large portion of trade secrecy licenses from coverage. Section 2B-104(5) excludes those parts of contracts that cover "personal or entertainment services by an individual or group of individuals, other than a contract of an independent contractor to develop, support, modify, or maintain software." Because many trade secrecy cases arise in the employment situation, and because many employment contracts deal specifically with the employee's obligations regarding secret information learned on the job, it is also possible to interpret this provision as taking much of trade secrecy out of the ambit of Article 2B.

These exclusions are, however, likely to receive a rather narrow reading. The interpretation of section $2 \mathrm{~B}-104(5)$ proposed above may not be what the drafters intended. The reporter's notes on this section speak of this provision as dealing with the services of employees, not with their knowledge. ${ }^{72}$ But even if the suggested interpretation is the right one, both subsections (2) and (5) will probably be of little significance to trade secrets. First, section 2B-104 contemplates partial coverage of mixed licenses (licenses of covered and noncovered technologies). Courts can therefore construe the provision as applying Article $2 \mathrm{~B}$ to those portions of a license that cover trade secrets and not to those portions covering employment issues or related patents. ${ }^{73}$ More important, section 2B-103(b)(3)(B) applies Article 2B to all aspects of a contract when the "predoininant purpose of the transaction" is within

69. U.C.C. \& 2B-103 reporter's notes 3(c), 3(d) (Annual Meeting Draft, July 24-31, 1998). Examples include the linear motion-picture and sound-recording industries, which are exempted in the 1998 Annual Meeting Draft by § 2B-104(8).

The exclusion of sectors with the legal sophistication and the political clout to know enough ahout Article $2 B$ to seek exclusion raises questions about the entire enterprise. To the extent that these groups have identified serious problems with Article 2B, the remedy should be to change the law, not to omit these sectors. In many cases, their concerns are shared by others, and more general changes in Article 2B would benefit everyone rather than particular industries.

70. Id. § 2B-104(2).

71. Id.

72. See U.C.C. $\$ 2 B-104$ reporter's notes 2, 6 (Annual Meeting Draft, July 24-31, 1998).

73. See id. $\S 2 \mathrm{~B}-103$ (b) reporter's note 2 (d). 
its scope. ${ }^{74}$ In the creative sectors, trade secrecy issues will often be the most important part of employment contracts. As to patent licenses, in the usual case, the licensing of related know-how is not the predominant purpose of the transaction. However, in those cases where the validity of the patent is in doubt, an objective evaluator of the licensee's goals might come to the conclusion that licensing the know-how was a key purpose. $^{75}$

It is also likely that courts will apply Article $2 \mathrm{~B}$ to otherwiseexcluded trade secrets as a inatter of common law. Courts that have become accustomed to relying on Article $2 \mathrm{~B}$ in some trade secrecy areas may come to think that all trade secrets should be considered alikethat is, to see jurisprudential advantages in amalgamating into the law that covers free-standing discoveries and software trade secrets, ${ }^{76}$ the law that governs rights to information related to patented technologies. It is worth noting that prior drafts of Article $2 \mathrm{~B}$ anticipated that it would apply to other fields by analogy. ${ }^{77}$ Although that language was removed from later drafts, the reporter's notes do not bar common law adoption of its principles; indeed, the reporter's notes contain many patent examples. ${ }^{78}$ In the final analysis, it is not likely that courts will maintain several separate bodies of laws on the licensing of intellectual property absent special circumstances arising in the context of particular transactions. In a sense, that is also the most desirable result. Any other result would introduce a level of uncertainty into contracting that is not consistent with the overall objectives of Article 2B.

The other exemptions from Article $2 \mathrm{~B}$ coverage are found in section 2B-105, which acknowledges that Article $2 \mathrm{~B}$ is limited by federal law ${ }^{79}$ and is supplemented by "principles of law and equity," including state trade secret laws and unfair competition laws. ${ }^{80}$ Section $2 \mathrm{~B}-105$ also contains specific exemptions related to electromic transactions and consumer protections. ${ }^{81}$ Depending on how these sections are interpreted, some of the concerns raised previously disappear. For example, courts could conclude that section 2B-105(b) means, first, that any slift that

74. Id. § 2B-103(b)(3)(B).

75. Cf. Rochelle Cooper Dreyfuss, Dethroning Lear: Licensee Estoppel and the Incentive to Innovate, 72 VA. L. REv. 677, 693-707 \& n.66 (1986) (noting the predominance of hybrid licenses and suggesting reasons why a patent of questionable validity might be licensed).

76. Software trade secrets are apparently covered irrespective of whether they can be classified as know-how. See U.C.C. § 2B-103(a)(1) (Annual Meeting Draft, July 24-31, 1998).

77. See, e.g., U.C.C. \$ 2B-103 reporter's note 5(b) (Draft, Nov. 1, 1997).

78. See, e.g., U.C.C. art. 2B Prefatory Note at 8 \& n.7, §§ 2B-103 reporter's note 3(c), 2B-201 reporter's note 1, 2B-308 reporter's note 2, 2B-501 reporter's note 1 (Annual Meeting Draft, July 2431,1998 ).

79. See id. $\$ 2 \mathrm{~B}-105$ (a) (providing that any provision of Article 2B preempted by federal law is to that extent unenforceable).

80. Id. $\$ 2 \mathrm{~B}-105(\mathrm{~b})$.

81. See id. $\S \S 2 \mathrm{~B}-105(\mathrm{~d})$ (electronic transactions), 2B-105(c) (consumer protection). 
Article 2B makes in the line between what is "known" and what is "secret" is trumped by a state law that explicitly limits exclusivity to information that is valuable because it is secret; second, that the consumer protection provision of section $2 \mathrm{~B}-105(\mathrm{c})$ is intended to protect consumers who want to reverse engineer the products they purchase; or third, that section 2B-105(a) preempts enforcement of contracts that bar free use of public information or reverse engineering. These sections, however, are very general. Absent more guidance it is likely that thcse two provisions will not significantly limit Article $2 \mathrm{~B} .^{82}$

\section{b. Choices of Law and Forum}

Section 2B-107 sets out a choice of law rule to govern multijurisdictional licensing transactions. For agreements relevant to trade secrecy, the key rules are section 2B-107(a), which makes most contractual choices of law enforceable; section 2B-107(b)(1), which imposes as a default rule the law of the licensor on all access contracts; ${ }^{83}$ and subsections $2 \mathrm{~B}-107(\mathrm{~b})(3)$ and (c), which use as a default rule a "most significant relationship" test to determine the applicable law in other situations. ${ }^{84}$ The first provision is unexceptional. As the reporter's notes imdicate, choice of law clauses are commonly enforced. Besides, the notes suggest that courts can refuse to enforce laws that violate fundamental local policies. ${ }^{85}$

The other choice of law rules are somewhat more problematic, especially for trade secret licenses. In evaluating these provisions, it is important to keep in mind that the "law" being" picked may be not just contract law, but all relevant law, presumably including trade secrecy law. Since there nuay be inportant differences in the exclusive rights that jurisdictions recogmize, the choice of law that Article $2 \mathrm{~B}$ makes could ultimately influence the level of innovation on a nationwide basis. Consider, for example, a potential inventor in jurisdiction $\mathrm{A}$, trying to decide whether to muest resources in creative activity. If the core incentive-driven premise of intellectual property law is correct-that the inventor's decision turns on a promise of exclusivity - then jurisdiction A's decision to recognize an exclusive right in the work would be undermined if the transaction that the inventor enters into is governed by

82. These issues will be reconsidered at length, infra, in Part II. I understand, however, that additional materials are being considered that would amplify the commentary on federal policy.

83. An "access contract" is defined by section 2B-102(a)(1) as "a contract to electronically obtain access to ... an information processing system."

84. The "significant relationship" test is refined by section 2B-107(c). It deals with the case in which the jurisdiction with the most significant relationship is outside the United States and that jurisdiction does not have a law the equivalent of Article $2 B$ that applies to U.S. parties. In that case, the law of the U.S. jurisdiction with the most significant relationship to the transaction will control.

85. See U.C.C. \& 2B-107 reporter's note 1 (Annual Meeting Draft, July 24-31, 1998). As notcd earlier, supra note 38 , I am excluding consumer contracts from consideration. 
the law of jurisdiction $B$, which permits free access. In other words, it is almost always the case that the proper choice of law rule, at least on the question whether a trade secret exists, is the law of the place where the imvention was made. That probably will be the usual result under subsection $2 \mathrm{~B}-107(\mathrm{~b})(1)$ for access contracts because that subsection designates the law of the licensor, which will be the developer in most cases. Whether subsections $2 B-107(b)(3)$ and (c) reach the same result depends entirely on how "most sigmificant relationship" is interpreted. The reporter's notes leave this to the "factors test" of the Restatement (Second) of Conflicts of Law, ${ }^{86}$ thereby creating a level of uncertainty that is inconsistent with the predictability-enhancing aims of Article $2 \mathrm{~B} .{ }^{87} \mathrm{Had}$ Article $2 \mathrm{~B}$ paid more attention to such "upstream" issues as the conditions that give rise to a creative environment, it could have, at the least, provided more guidance on what activities should be considered significant. ${ }^{88}$

Multijurisdictional cases usually create forum choices as well. Section 2B-108 allows parties to select an exclusive forum unless the choice is unreasonable or unjust. This sort of freedom is, agam, familiar ground in most commercial dealings. The freedom is not, however, total. Parties can contractually waive their objections to personal jurisdiction, but they cannot contractually alter the subject matter jurisdiction of the courts in which they litigate. ${ }^{89}$ Thus, parties cannot select a federal forum for cases raising only state law issues, or a state forum for cases raising copyright or patent issues. Nonetheless, the provision may alter the allocation of cases at the margm, because licensing disputes can soinetimes be characterized as either a contractual breach or as a claim for copyright or patent infringement. As noted elsewhere, if state courts are to become the favored forum for these disputes, it would be wise to include more material on issues, such as preemption, with which they are not likely to be familiar.

86. Restatement (SeCOND) OF Conflicts OF LAW § 6 (1988).

87. See U.C.C. § 2B-107 reporter's note 6 (Annual Meeting Draft, July 24-31, 1998). This is not to say that this is the result courts now tend to reach. See, e.g., Softel lnc. v. Dragon Med. \& Scientific Communications, Inc., 118 F.3d 955, 967 (2d Cir. 1997) (applying New York trade secrecy law to a multistate transaction, because misappropriation occurred in New York and the parties maintained offices there).

88. Of course, the law of the place of invention could be used on trade secrecy issues and another law could be used on purely contractual inatters. That the drafters contemplate mixing laws is supported by section 2B-103(b)(1). On the other hand, reporter's note 5 to section 2B-105 seems to rule out an approach that would mix the laws of several states. Since dépeçage has many problens of its own, it would be useful if the commentary expressly addressed the issue.

89. Compare Carnival Cruise Lines v. Shute, 499 U.S. 585 (1991) (holding parties can choose a forum contractually), with Franchise Tax Bd. v. Construction Laborers Vacation Trust, 463 U.S. 1 (1983) (holding parties cannot choose to have a nonfederal case heard in federal court). 


\section{c. Right to a Refund}

One of the main ways that Article $2 \mathrm{~B}$ changes prior law is by making it clear that contractual restrictions on usage will be enforced. Since parties may not realize that they are receiving work subject to restrictions, section 2B-112 can be an important element in making such contracts fair to all sides. It deems unenforceable those contracts that create restrictive terms without giving the party subject to the restrictions an opportunity to return the material for a refund. ${ }^{90}$

With respect to most imtellectual property law, this refund provision makes good sense. Most works are like the musical work that Article 2B uses as its illustration: impossible to enjoy fully without possession of the copy ${ }^{91}$ For these works, return is often a genuine possibility. For certaim trade secrets, however, there may be a problem. Although there are trade secrets that cannot be committed to memory-customer lists, repair records, and protocols are examples-many can be remembered easily and exploited long after the copy is returned. If there is no way to prevent the licensee from seeing the work before returning it, or to monitor post-return use of the information, this provision could work a hardship. Admittedly, all that is required to avoid the return rule is to call restrictive terms to the attention of the party..$^{92}$ However, until trade secret holders become fully familiar with Article 2B, the requirement could confound their expectations. ${ }^{93}$

90. See U.C.C. \& 2B-112 reporter's note 2 (Annual Meeting Draft, July 24-31, 1998). That disclosure is necessary for fairness does not, of course, mean that it is sufficient.

91. See id. § $2 \mathrm{~B}-112$ reporter's note 4.

92. See id. \& 2B-112(a).

93. Interestingly, in other parts of Article 2B, this problem is carefully considered. For example, section 2B-604 makes the right to inspect, to refuse, and to revoke inapplicable to situations in which the licensee receives substantially full value upon receipt of information. See id. \& 2B-604. Perhaps the omission here reflects the document's origin as directcd at computer programs, which can be blocked until licensing restrictions are accepted.

Depending on how section 2B-112 is imterpreted, it may create another problem. According to reporter's note 4, "the refund [right] exists only for the first user." $I d$. § $2 \mathrm{~B}-112$. If this means that restrictions on use are enforceable against third parties without notice, then this works a change in trade secrecy law, which stresses the need to notify recipients of information when its use is restricted. See, e.g., UNIF. TRAdE SECRETS ACT \& 1(2)(B)(II), (III), 14 U.L.A. 438 (1990). The Restatement (Third) of Unfair Competition has the same effect. See RESTATEMENT (THIRD) of UNFAIR Competition \& 41(b)(1)-(2) (1995). This limitation on enforcement is an important protection of the creative and dissemination process. Without a notice/scienter provision, the possessor of information could waste creative resources inproving on a technology or waste capital resources commercializing it, only to find out that the improvement or plant could not be later utilized under the terms of the contract. It is difficult to believe, however, that Article $2 \mathrm{~B}$ intends to eliminate a notice/scienter requirement. For example, section 2B-507(b) and its reporter's note 3 acknowledge that there can be a good faith purchaser of trade secrets. 


\section{Formation and Terms}

The second part of Article $2 \mathrm{~B}$ sets out rules for deciding when a contract is formed and for determining its terms. Apart from matters discussed previously, such as the right to return for a refund material subject to surprising terms, these provisions mostly work little change on traditional contracting rules, at least outside the mass market context. Article $2 \mathrm{~B}$, however, creates two important exceptions to basic contracting principles. It also includes two other sections worth mentioning.

\section{a. Article 2B's Statute of Frauds}

The first iunportant exception is section 2B-201(a), which is Article $2 B$ 's statute of frauds. Its requirenient of an authenticated record ${ }^{94}$ is, as the drafters acknowledge, not always present in current patent and copyright law; ${ }^{95}$ it may alter practice in trade secrecy situations as well. ${ }^{96}$ The reporter's notes justify the requirement on the ground that the need for protection is high in situations where rights are intangible and interests are divided among inany parties. ${ }^{97}$ And, as noted earlier in the margin, anything that increases the licensee's awareness of restrictions imposed on use is beneficial. ${ }^{98}$ Otherwise, possessors of information can find themselves in a position where they have invested resources (for example, in making improvements) that they cannot later exploit.

Since many trade secrecy licenses are heavily negotiated, the requirement may pose few practical difficulties once parties know about it. There nuay, however, be some situations where a statute of frauds will give rise to significant problems. Consider, for example, research in biotechnology. It is often characterized by a high degree of collaboration among commercial actors and parties with little sophistication about legal matters (such as academic research scientists)..$^{99}$ It is hard to know the exact extent to which the participants in these ventures are able to allocate their rights fully, especially in writing. In all likelihood, they have written agreements regarding patent rights, and a set of informal

94. An "authenticated record" is Article 2B's term for a signed writing. See U.C.C. \$ 2B-102(a)(3), (39) (Annual Meeting Draft, July 24-31, 1998). Section 2B-201 contains exceptions for certain agreements, such as for short-term licenses, see id. \$ 2B-201(a)(2), for licenses involving consideration under $\$ 5000$, see id. \$ 2B-201(a), for contracts involving already-disclosed information, see id. $\$ 2 \mathrm{~B}-201$ (c)(1), and in certain instances, for contracts between merchants, see id. $\S 2 \mathrm{~B}-201$ (d).

95. See id. § 2B-201 reporter's note 3 .

96. Subsection 2B-303(c) makes section 2B-201 applicable to contracts that, as modified, are within section 2B-201's provisions. See also id. § 2B-406(b)(1) (providing method of disclaiming or modifying varranties).

97. See id. \$ 2B-201 reporter's note 1 .

98. See supra note 93.

99. See generally Walter W. Powell, Inter-Organizational Collaboration in the Biotechnology Industry, 152 J. Institutional \& THEORETICAL ECON. 197 (1996). 
expectations with regard to other technologies discovered; these expectations will only be concretized once the parties know exactly what they have produced. In that context, the statute of frauds could undermine expectations, which would be very unfortunate. Economists who have studied cumulative research have suggested that the making and enforcement of prior agreements (that is, prior to the initiation of new projects) is a very effective way to avoid the problem of blocking patents. Such agreements also tend to be efficient ways to distribute benefits in a manner that encourages research on both pioneer inventions and improvements. ${ }^{100}$

Tellingly, Article 2B excludes patent licensing from its coverage precisely because there are varying practices in the biotechnology industry. ${ }^{101}$ Because there can be no assurance that the fruits of these collaborative efforts will always lead to patents, perhaps the exclusion ought to apply more broadly to include trade secrets deriving from research im biotechnology. ${ }^{102}$ The other alternative, of course, would be to eliminate the writing requirement. The drafters of Article $2 \mathrm{~B}$ have been unable to achieve consensus about the statute of frauds, ${ }^{103}$ possibly because courts have generally proved able to discern the existence of an agreement from the actual behavior of the parties. Since courts in cases involving information products have proved equally able-even in situations where inchoate ideas are transferred ${ }^{104}$ - the special need for a writing in intellectual property transactions deserves further examination. ${ }^{105}$ Moreover, this imposition of a formality flies in the face of the

100. Cf. Suzanne Scotchmer, Standing on the Shoulders of Giants: Cumulative Research and the Patent Law, 5 J. Econ. Perspectives 29, 35-37 (1991). Strong and reliable rights, which can provoke negotiation between pioneer and improver, are another important way to allocate surplus. See Mark A. Lemley, The Economics of Improvement in Intellectual Property Law, 75 TEx. L. Rev. 989 (1997).

101. See U.C.C. § 2B-104 reporter's note 3 (Annual Mecting Draft, July 24-31, 1998); see also id. § 2B-103 reporter's note 4(c).

102. Indeed, courts have had a very checkered career in terms of their hospitality to claims in biotechnology. See, e.g., In re Wright, 999 F.2d 1557, 1551-64 (Fed. Cir. 1993) (enunciating a high standard for enablement); Fiers v. Sugano, 984 F.2d 1164, 1206 (Fed. Cir. 1993) (setting out a difficult standard for conception); Amgen, Inc. v. Chugai Pharmaceutical Co., 927 F.2d 1200, 1212-14, 121518 (Fed. Cir. 1991) (enunciating a high standard for enablement); In re .O'Farrell, 853 F.2d 894, 90104 (Fed. Cir. 1988) (establishing strict standards for nonobviousness). Ex parte Aggarwal 23 U.S.P.Q.2d (BNA) 1334 (Bd. Pat. App. 1992) (same). The most recent cases from the Federal Circuit have articulated a relatively relaxed standard of nonobviousness. See, e.g., In re Deuel, 51 F.3d 1552, 1557-60 (Fed. Cir. 1995); In re Bell, 991 F.2d 781 (Fed. Cir. 1993). Some doubt exists about the continuing vitality of these cases given the current state of knowledge in the field. Morcover, there is reason to doubt that the patents that survive under Bell and Deuel will have the cominercial significance necessary to earn significant patent rewards.

103. More exactly, the number of votes taken on the provision seems unusually large. See U.C.C. § 2B-201 committee votes (Draft, Mar. 1998).

104. See, e.g., Sellcrs v. American Broadcasting Co., 668 F.2d 1207 (11th Cir. 1982); Lueddecke v. Chevrolet Motor Co., 70 F.2d 345 (8th Cir. 1934).

105. Much of what is said here also applies to other requirements for a writing. See, e.g., U.C.C. $\S 2$ B-303(c) (Annual Meeting Draft, July 24-31, 1998). Note that even if the statute of frauds were 
decreasing reliance on formalities in intellectual property law in general. ${ }^{106}$ Hopefully courts will minimize the potentially disruptive effects of this provision by broadly construing subsection $2 \mathrm{~B}-201(\mathrm{c})(1)$, which makes agreements enforceable when performance has been both tendered and performed.

\section{b. Article 2B's Article 2-207 Analogue}

Section $2 B-209$, the second important exception to traditional contracting rules, also deserves close scrutiny because it imports into intellectual property law U.C.C. section 2-207, Article 2's solution to contracts that fail either because the parties are engaged in a "battle of the forms" or because they have omitted critical terms. Thus, Article 2B provides that a contract can be formed through the conduct of the parties, with the court incorporatimg into the contract those terms on which the parties agreed, terms that are evident through their behavior, as well as terms deriving from intellectual property law and other U.C.C. provisions. $^{107}$

There are two-possibly three-reasons to be concerned with section 2B-209. First, because it is new, there is likely to be a transition period during which parties will be surprised to find themselves bound to obligations arising as a matter of this law. Second, the notion of contractual formation in the absence of real agreenent does not comport with the drafters' stated rationale for imposing a statute of frauds - that rights in intangibles demand more documentation. (Reconciling these provisions in practice may also prove problenatic.)

A third possible reason for concern has to do with the scope of contracts that arise by reason of performance. Ostensibly, the 1998 Annual Meeting Draft makes a sigmificant improvement over earlier iterations. These older drafts allowed the court to find a contract even if the parties had not agreed on scope, and then instructed the court to interpolate the licensor's views. ${ }^{108}$ The idea of deferring to the licensor in this way was criticized extensively on the ground that it overlooked an important distinction between tangibles and intangibles: with intangi-

eliminated, claims to compensation for the use of inchoate rights would be severely limited under Article 2B. See id. § 2B-206.

106. For example, in contrast to earlier copyright legislation, the Copyright Act of 1976 permits, but does not mandate, notice. See 17 U.S.C. $\$ 401$ (a) (1994). Section 2B-201 seems to draw some strength from the fact that assignments of copyrights and patents inust be in writing, as required by 17 U.S.C. $§ 204$ (1994) and 35 U.S.C. $\$ 261$ (1994) respectively. The focus of this argument, however, may not be on the contracting parties, but rather on other potential users, who need to know whose permission they need in order to utilize the work.

107. See also U.C.C. § 2B-202(c) (Annual Meeting Draft, July 24-31, 1998) on formation of contracts with open terms, and $i d . \S \S 2 \mathrm{~B}-203$ and $2 \mathrm{~B}-207$, together providing that a contract is formed when one party takes action to which the other assents.

108. See, e.g., U.C.C. \$ 2B-209(d) (Draft, Mar. 1998). 
bles, there is no "there there." That is, a party in possession of one widget knows she has only one. She can, therefore, evaluate a contract from partial performance. In contrast, a party possessing a method for producing a widget does not have any inherent way to know how many times and in what circumstances she can utilize the method. Since the value of a license for intangibles is almost totally dependent on the restrictions it contains, it was argued that without a meeting of the minds on scope, no course of performance should ever be considered a contract.

The drafters have apparently come to agree with this assessment that a meeting of the minds is necessary, for section 2B-209(b) now provides that if the parties do not agree on a material element of scope, a contract cannot be formed by conduct. ${ }^{109}$ However, the import of this provision remains im some doubt, for notwithstanding the text, the reporter's note suggests that licensor's views should control. According to the note, "[i]n the absence of contrary agreement, the information provider can define what it is providing." 110 Presumably, this means that once the product has changed hands, there is, in fact, an enforceable agreement, but that the licensee's position as to its scope is not relevant. Indeed, the reporter's note retains much of the language of the prior, criticized, drafts. It continues to state that a "party cannot resort to a court to obtain that product which it failed to obtain from the licensor by negotiation," and that a "vendor ... cannot be forced to have given an unlimited, [sic] license... simply because a competing form stated terms that conflict with [the licensor's contemplated restrictions]." Had the drafters really adopted the argument that no contract can be formed without an agreement on scope, what they would have provided is a right in licensors to the return of any product previously furnished. In cases where return is not possible (trade secret cases are important examples), perhaps it would be better to give the court the power to impose a scope term that is reasonable in light of the circumstances and the practices within the relevant industry.

I now turn my attention to two other provisions in part 2 of Article $2 \mathrm{~B}$ : sections $2 \mathrm{~B}-206$ and $2 \mathrm{~B}-208$. Even though they deal with issues

109. See U.C.C. § 2B-209(b) (Annual Meeting Draft, July 24-31, 1998).

110. Id. § 2B-209 reporter's note 7.

111. Id. Identical language appears at U.C.C. § 2B-209 reporter's note 7 (Draft, Mar. 1998). Sections 2B-203 and 2B-207 of the 1998 Annual Meeting Draft, together, may be to the same effect. They provide that a contract is formed when one party takes an action to which the other assents. These provisions appear neutral as between licensor and licensee, but in practice, may tend to favor licensors in that the licensor will usually be the party that initiates an offer by shipping informational products. Acceptance by the licensee may then put the liccnsee in the position of having accepted the licensor's terms. 
slightly beyond the scope of this Article, they are illuminating, and thus merit brief attention.

\section{c. Other Methods of Formation}

The first of these provisions is section 2B-206, which creates two relatively easy ways to acquire intellectual property rights. Under section 2B-206(a), posting a notice and documenting behavior consistent with consent is an adequate way to acquire rights in the works noticed. The reporter's note gives as an example a chat room that is entered for the first time with a screen that states that participation grants the operator certain rights to the comments made in the rooin. ${ }^{12}$ The user who then posts a message releases all rights in it to the operator.

Additionally, section 2B-206(b) deals with what is sometimes called the "law of ideas"-suggestions for new products made outside the context of preexisting agreements. It provides that no obligation to pay for use of an idea arises from the receipt of that idea, even in industries in which there is a custoin of acquiring ideas for development. ${ }^{113}$ If the recipient has a procedure for receiving submissions and makes the submitter aware of it, then the only way to create an obligation is by following the recipient's procedure. ${ }^{114}$ Even where there is a contract, there is no right to enforce it unless the information meets the standard set out by Article 2B: it must be confidential, concrete, or novel to the industry. ${ }^{115}$

These contract formation provisions are surprising because of their contrast with the rest of Article 2B, which emphasizes the retention rather than the loss of rights. They are also arguably harder on the "licensor" (the person generating the work or the idea) than is current law. ${ }^{116}$ Moreover, the section is likely to have its principal impact on parties who are not legally sophisticated.

Admittedly, there is so much doctrinal disarray in the area of

112. See U.C.C. \$ 2B-206 reporter's note 2 (Annual Meeting Draft, July 24-31, 1998).

113. See id. \$ 2B-206(b)(1)-(2).

114. See id. $\S 2 \mathrm{~B}-206(\mathrm{~b})(\mathrm{C})$. Note that this subsection is misnumbered in the 1998 Annual Meeting Draft. It should be numbered "2B-206(b)(3)."

115. See id. \$2B-206(c).

116. Subsection 2B-206(a), for example, would change the usual rule that the sender of letters retains the copyright in thenn. See, e.g., Salinger v. Random House, Inc., 811 F.2d 90, 94-95 (2d Cir. 1986). As that subsection's reporter's note 2 , illustration 1 , makes clear, posting a notice on a chat room creates a rclease of all rights in rcsponses.

In connection with the law-of-ideas issues raised by $\$ 2 \mathrm{~B}-206(\mathrm{~b})$, see, e.g., Matarese v. MooreMcCormack Lines, I58 F.2d 63I (2d Cir. 1946), which essentially creates a right to compensation on the mere transmission of a concrete idea, despite the failure of an express contract. See also Blaustem v. Burton, 88 Cal. Rptr. 319 (Cal. Ct. App. 1970), Yadkoe v. Fields, 151 P.2d 906 (Cal. Ct. App. 1944), and Buchwald v. Paramount Pictures Corp., 13 U.S.P.Q.2d 1497 (Cal. Super. Ct. 1990), which arguably impose a lesser standard on idea submitters in the entertainment field, where new ideas are (arguably) a rare commodity. 
contract formation-especially with respect to the law of ideas-that almost any codification is welcome. However, the reasons behind the disarray hint at problems that the draft ignores. For example, in the context of the law of ideas, many participants in the information industries are inundated with suggestions that are well-known or already under development. They also find themselves subject to claims for compensation for the use of ideas that are only tenuously related to the projects on which the claims are based. ${ }^{117}$ On the other hand, however, there is a notion (sometimes unacknowledged) that those who invent deserve a reward-or the reverse, that those who have not sowed should not reap. ${ }^{118}$ Courts have long struggled to find a way to protect deserving submitters (who are unlikely to be aware of the law) without exposing recipients to too many claimants. They are not, however, as resistant to such claims as is the current draft, perhaps because judges value the upstream part of development inore than do the drafters of this Article-and perhaps because the drafters received much more advice from coalesced groups in the information industry (such as entertainment producers) than from dispersed individuals (such as idea submitters). ${ }^{119}$

\section{d. Mass Market Contracts}

The second provision worth mentioning, section 2B-208, controls the formation of mass inarket contracts. Under this provision, any term that is not unconscionable becomes a part of the contract if the party agrees to the license by manifesting assent. ${ }^{120}$ "Unconscionability" is not defined by the statute. ${ }^{121}$ However, a reporter's note makes it clear that terms conflicting with federal policy could be regarded as unconscionable. ${ }^{122}$ Unfortunately, the note takes "a neutral position" on what should be considered conflicting-on what the draft calls "difficult

117. See Harry R. Olson, Jr., Dreams for Sale, 23 LAw \& Contemp. Probs. 34 (1958). See also Paul Goldstein, Copyrights, Patents, Trademarks and Related State Doctrine 26-57 (4th ed. 1997).

118. See, e.g., International News Serv. v. Associated Press, 248 U.S. 215, 239 (1918).

119. It is interesting to note that the draft of November 1, 1997, gave an entertainment law example in the section on releases - the release of a right of publicity. See U.C.C. § 2B-206 reporter's note 2, illus. 1 (Draft, Nov. 1, 1998). That illustration was dropped in the 1998 Annual Meeting Draft. One can only speculate why the drafters shifted readers' focus away from the entertainment sector.

120. As noted earlier, a refund option is required if the license cannot be reviewed prior to payment. See supra Section I.B.1.c.

121. See U.C.C. § 2B-110 (Annual Meeting Draft, July 24-31, 1998). The author understands, however, that a "sense of the house" motion has been passed that would add language and explanatory material on federal policy, either to section $2 \mathrm{~B}-110$ or to section 2B-105. See Electronic Mail from Harvey Perlman, Nebraska Commissioner on Uniform State Laws, NCCUSL, to Rochelle Cooper Dreyfuss (Sept. 22, 1998) (on file with author).

122. See id. \& 2B-208 reporter's note $4(\mathrm{~b})$. 
federal policy issues." ${ }^{23}$ As noted in the next Part of this Article, it is a real pity that the drafters were unwilling to delve further into the issue. Article $2 \mathrm{~B}$ is aimed at creating a new environment for exploiting intellectual works, including new types of intellectual works. The drafters have thought more about these problems than have federal courts or federal lawmakers. Simce the drafters' assessment of the importance of contractual freedom emerges loud and clear in any event, more on their rationale would be appropriate. A clear articulation of their justification, along with their views on how to balance contract policy (and the proprietary interests of creators) against the interests of users, would be most helpful. In contrast to the drafters, many of the courts that hear the early cases will be dealing with these issues as matters of first impression. Ironically, a statement of the drafters' goals might also go a long way to persuading courts-including the Supreme Court-to be hospitable to the flexible regime they favor. For many of the same reasons, it would be useful to have the drafters' views on the relationship between unconscionability and pro-user policies emanating from state law.

\section{Construction}

The third part of Article 2B establishes rules of contract interpretation. To the extent possible, these rules track the construction principles of Article 2. Harmonizing the Articles in this way has the advantage of allowimg courts to build upon the existing case law interpreting Article 2. Judges should nevertheless remain alert to the important differences in the subject matter that these Articles control. For example, the behavior of the parties plays an important role in contract construction: under section 2B-302, meaning can be derived from repeated performances known to the other party. This rule of interpretation will work for trade secret cases only if courts remember that trade secrets, by their nature, are easily exploited in secret. Courts therefore must pay significant attention to the section's proviso that actions are relevant to interpretation only when they occur in circumstances in which the other side enjoys an opportunity for objection. ${ }^{24}$

This third part of Article 2B also mcludes some new contract interpretation law. Indeed, sections 2B-307, 2B-309, and 2B-310 are among the most interesting additions that Article $2 \mathrm{~B}$ makes to intellectual property law. Section 2B-307 attempts to resolve questions concerning the scope of grants, imcluding that perennial favorite in copyright law: whether rights in "all inedia" include rights im media developed

123. Id.; see also id. § 2B-208 reporter's note 6. For an extensive discussion of mass market contracts, see generally Lemley, supra note 13.

124. See U.C.C. § 2B-302(a) (Annual Meeting Draft, July 24-31, 1998); see also id. § 2B-306 (adopting a good faith standard for output, requirements, and exclusive dealing terms). 
after the contract was made. ${ }^{125}$ Trade secrecy lawyers should examine this section with particular care, especially how it allocates rights to improvements, ${ }^{126}$ and how it interprets what rights impliedly are granted or withheld. ${ }^{127}$ Section 2B-309, which applies between merchants, creates special duties for handling information that one party gives to another for purposes of performing a contract. ${ }^{128}$ It provides that when the recipient knows the information is confidential, the recipient may use it only for the purposes authorized or necessary for performance, must maintain its confidentiality in a nanner consistent with industry practice, and inust destroy or return it after the agreement terminates. ${ }^{129}$ Significantly, these obligations apparently can be triggered by the characterization of the information as confidential, not by the traditional trigger, the information's status as secret. ${ }^{130}$

For trade secret holders, the most important provision governing contract interpretation is probably section $2 \mathrm{~B}-310$, which permits parties to use electronic means to enforce contractual linitations on use. For example, this section permits a software licensor to embed into a program a monitor that counts the number of times the licensee uses the program and then shuts off access when the licensee reaches the limit specified in the contract. Although as a general matter, self-help remedies raise issues of procedural due process, ${ }^{131}$ they can be uniquely useful in connection with trade secrets, where rights holders often experience difficulty in inonitoring compliance. The provision is, however, problematic in at least four respects. First, there appears to be no requirement that the licensee be notified that the device actually is being embedded. ${ }^{132}$ Since trade secret licensees routinely may discount priceper-use by the likelihood of nondetection, knowledge that the device

125. See id. \& 2B-307(f)(1).

126. See id. $\$ 2 B-307$ (d) (providing that neither party has an obligation to share improvements with the other).

127. See id. § 2B-307(a).

128. See id. \$2B-309.

129. See id. § 2B-309(c). These obligations do not apply to transactional information. See id. § 2B-309(d).

130. For further discussion of the ramifications of this trigger for innovation policy, see supra note 62 and text accompanying; and infra text accompanying note 211. See also infra text accompanying notes 251-253.

131. See, e.g., Connecticut v. Doehr, 501 U.S. 1 (1991) (holding that prejudgment attachment without notice and a hearing violates due process). The draft recognizes these procedural issues in section 2B-715, which provides for expedited hearings in the event of breach. The March 1998 Draft explained that expedited hearings would "reduce the necd for self-help," see U.C.C. \& 2B-715 reporter's note 3 (Draft, Mar. 1998), but the 1998 Annual Meeting Draft deletes this explanation from the reporter's notes.

132. U.C.C. § 2B-310(b)(1) (Annual Meeting Draft, July 24-31, 1998) requires that the eontract authorize its use, but the term need not be conspicuous and authorization is not quite the same as notification. Section 2B-310(b)(4) requires that a warning be given before activation, but that does not fully deal with the problem either. 
will be included would enhance the fairness of the bargaining process. Second, the licensor bears no liability for losses created by the operation of the device. ${ }^{133}$ It is not clear whether this means losses caused by the unavailability of the information, or the havoc that the device could wreak in the system in which it was used. Third, in the copyright context, the monitor can be used to exclude uses that are considered fair under copyright law. For trade secrecy, there is no clear-cut fair use defense. Nonetheless, there may be cases where flexibility is warranted, but the device would interfere with a court's ability to permit it. Fourth, if these devices can detect and prevent activities constituting reverse engineermg, their inclusion could clash in a fundamental way with national policy, which privileges copying. ${ }^{134}$

Despite these concerns, these provisions on contract construction are quite hospitable to federal intellectual property policy. For example, section 2B-307 makes clear that uses permitted under federal law are not breaches. ${ }^{135}$ It also sets out an allocation of rights to improvements consistent with federal thinking. ${ }^{136}$ Similarly, section 2B-308, which covers duration, invokes temporal limits in other laws-including federal laws. ${ }^{137}$ There are, however, a few worrisome possibilities. For one, it is not clear whether references to the public-regarding aspects of federal law are also applicable to trade secret licenses. Further, these sections contemplate that parties can contract around virtually all of the provisions. As will be discussed later, some deviations that the parties might make could be imconsistent with federal policy. Finally, for all the attention paid to federal law, there is little emphasis on making sure that these provisions are consistent with state policy.

\section{Warranties}

Trade secrecy lawyers will want to scrutinize part 4 , which covers warranties, with care. The provisions, once again, correspond generally

133. See id. \& 2B-310(d).

134. See, e.g., Sears, Roebuck \& Co. v. Stiffel Co., 376 U.S. 225, 231-32 (1963) (holding states are not free to prevent copying of articles in the public domain). Compare section 2B-707, which apparently allows a licensor to claim as damages compensation for all unauthorized uses, including (apparently) uses that could be construed as "fair use" under, say, copyright law. This was, however, clearer in prior drafts. See, e.g., U.C.C. § 2B-707 reporter's note 1, illus. 2 (Draft, Mar. 1998); U.C.C. $\$ 2$ B-707 reporter's note 4 (Draft, Nov. 1, 1997) (characterizing unauthorized uses as copyright infringement). Perhaps the drafters regard both problems as decided by subsection 2B-307(b)'s proviso that uses allowable under other law are not breaches. See U.C.C. \$ 2B-307 reporter's note 2, illus. 1 (Annual Meeting Draft, July 24-31, 1998).

135. See U.C.C. \& 2B-307 and reporter's note 2 (Annual Meeting Draft, July 24-31, 1998). But cf. id. $\$ 2 \mathrm{~B}-310$ (permitting electronic restraints).

136. See id. $\$ 2 \mathrm{~B}-307$ (d).

137. See id. § 2B-308 and reporter's note 2 . 
with the warranty provisions of Articles 2 and $2 \mathrm{~A} .{ }^{138}$ They take into account federal and other law as well. ${ }^{139}$ For example, subsection 2B-404(a) imposes a warranty of the accuracy of informational content. As in tort law, it runs only between parties who are in a special relationship of reliance. ${ }^{140}$ Nonetheless, in some instances, these warranties may be new to the trade secrecy industry and, in a few situations, inappropriate.

\section{a. Implied Warranties}

The implied warranties in section $2 \mathrm{~B}-405$, which cover representations concerning reasonable care and workmanlike effort, and fitness for a known purpose or for integration into a system, differ in some instances from what is warranted impliedly under the Restatement (Second) of Torts or current case law. ${ }^{141}$ They can be disclaimed, but licensors, of course, must be aware of both the need to do so and the effective method of doing so under Article $2 \mathrm{~B} .{ }^{142}$ Analogously, section 2B-403 creates implied warranties on the merchantability and quality of computer programs. It brings together several legal traditions concerning such warranties, while recognizing the distinctions between information products, goods, and services. ${ }^{143}$

\section{b. Affirmative Warranties}

Section 2B-401, which deals with affirmative warranties, is one of the provisions that raises some concern. Under subsection (b)(2), an exclusive licensor warrants that the rights licensed are "valid and exclusive within the scope of the license for the information as a whole to the extent the rights are recognized under applicable law." ${ }^{144}$ The question here is whether the intent is to allocate to the licensor only the risk that the licensor has done nothing to invalidate the intellectual property right, or the risk that the information being licensed is in the public

138. See, e.g., id. $\S 2 \mathrm{~B}-402$ reporter's note 2 (suggesting that courts can use decisional law under Article 2 to decide when representations become part of the bargain).

139. See, e.g., id. $\$ \S 2 \mathrm{~B}-401$ (c)(1) (making warranties subject to rights arising under intellectual property law), 2B-402(c) (acknowledging the First Amendment interests that surround the allocation of hability risk with respect to published informational content), $2 \mathrm{~B}-402$ reporter's note 4 (same); see also id. § 2B-409 reporter's notes (likening third-party liability doctrine in tort law to Article 2B's rules on third-party beneficiaries).

140. See id. \$2B-404 reporter's notes 1 and 2(c).

141. See id. § 2B-405 \& reporter's note 1 .

142. See id. $\$ 2 \mathrm{~B}-406$.

143. See id. \$ 2B-403 \& reporter's notes. Warranties can be disclaimed under section $2 \mathrm{~B}-406$. For a detailed treatment of Article 2B's implied warranty of merchantability, see Peter A. Alccs, W(h)ither Warranty: The B(l)oom of Products Liability Theory in Cases of Deficient Software Design, 87 CaLif. L. Rev. 269 (1999).

144. Id. $\$ 2 \mathrm{~B}-401(\mathrm{~b})(2)$ (emphasis added). The version in the earlier November 1,1997 , Draft omits the italicized phrase. See U.C.C. \$ 2B-401(a)(2) (Draft, Nov. 1, 1997). 
domain or otherwise useable by others. Reporter's note 4 to section 2B-401 implies that it is the public-domain risk that is being allocated, but that is a risk that trade secrecy licensors may not be willing to assume. Because trade secrets are just that-information that can be utilized secretly-licensors cannot always know who else is using the same technology, and whether there are so many other entities using it that a court will find the trade secret "generally known" and therefore invalid. As noted in the margin, ${ }^{145}$ the italicized language was added in recent iterations of Article 2B; one hopes it will be imterpreted as confining the warranty to activities taken by the licensor. In any event, once aware of the potential problem, licensors can disclaim the warranty by specific language. ${ }^{146}$

\section{c. Express Warranties and "Beta Models"}

Section 2B-402 is noteworthy as the first legislative attempt to deal with the emerging practice of furmishing selected customers with experimental versions of new products, so-called beta models. Under subsection 2B-402(a)(3), this conduct creates an express warranty that the final product will "reasonably conform" to the performance of the experimental version, as judged by a reasonable person in the position of the licensee. ${ }^{147}$ This warranty bears careful consideration as applied to trade secrets. It may be counter to the parties' understanding im situations where both sides know that the licensee's use of the sample will help the licensor perfect the product. ${ }^{148}$ More importantly, the warranty inay have an inadvertent effect on a licensor's ability to patent a final product. This is because the Patent Act requires inventors to apply for patents within a year of putting their products "on sale."149 Although licensing a beta model may not appear to be a sale, that word has taken on a technical meaning in the case law. First, the key issue is not the parties' characterization of the transfer, but rather whether inventors are "exploiting the commercial value of their inventions while deferring the beginning of the statutory term."150 Licensing is certainly an exploitation of value, and it is especially likely to be considered as such once Article 2B goes into effect because Article 2B will make licensing of trade secrets so much easier. Second, a transaction can be considered a sale even if the invention has not been reduced to practice: "[I]n

145. See id.

146. See U.C.C. § 2B-401(d) (Annual Meeting Draft, July 24-31, 1998).

147. See id. § 2B-402(a)(3).

148. That is, even though the parties may have different views on the trade-offs that should be made between the various performance features of the final product, the licensee might have accepted the possibility of such disagreement at the time the sample was provided.

149. 35 U.S.C. \$ 102(b) (1994).

150. Ferag AG v. Quipp Inc., 45 F.3d 1562, $1567-68$ (Fed. Cir. 1995). 
making the determination as to whether the invention was 'on sale,' '[a]ll of the circumstances surrounding the sale or offer to sell, including the stage of development of the invention and the nature of the invention, inust be considered and weighed against the policies underlying $\S 102(\mathrm{~b})$." ${ }^{151}$ Because courts naking these decisions look at such factors as the inventor's expectation that a prototype will work for its intended purpose, ${ }^{152}$ the inclusion of this iunplied warranty in a contract could lead courts to regard the furnishing of a sample as a sale. Finally, although it may seem that transfer of a beta inodel would qualify under the experimental use defense to the one-year on-sale bar, a "totality of the circumstances" test is used here, too. ${ }^{153}$ In cases where the circumstances of the transfer are ambiguous, the court may view the extension of this warranty as a factor that tips the balance toward sale.

\section{Transfers}

Article 2B's fifth Part deals with rules for transferring licenses from one party to another. These rules basically are designed to reflect analogous principles of intellectual property law. As in the Copyright Act, possession of a copy does not transfer rights in the work. ${ }^{154}$ Part 5 of Article 2B also takes up more subtle issues, such as whether possession of a copy constitutes ownership of the copy, ${ }^{155}$ and the timing of transfer. ${ }^{156}$ These, again, are provisions that those negotiating trade secrecy licenses need to keep in mind whenever they intend to make the licensed information the subject of a later patent application, for the timing rule articulated could determine when the invention went on sale. ${ }^{157}$

Prior versions of part 5's provisions on transfer were quite controversial. Although the provisions then at issue have been changed in recent drafts, it is not entirely clear whether the difficulties have been fully resolved-or, indeed, exactly what position Article $2 \mathrm{~B}$ now takes with respect to these contested inatters. The most substantial problem

151. Pfaff v. Wells Electronics, Inc., 124 F.3d 1429, 1433 (Fed. Cir. 1997), cert. granted, 118 S. Ct. 1183 (1998) (quoting Micro Chein., Inc. v. Great Plains Chein. Co., 103 F.3d 1538, 1544 (Fed. Cir. 1997)).

152. Thus, in Pfaff, the court held that the product was on sale because, among other things, "the district court found that Pfaff was confident, based on his drawings, that this invention would work." 124 F.3d at 1434 .

153. See, e.g., TP Lab., Inc. v. Professional Positioners, Inc., 724 F.2d 965, $971-72$ (Fcd. Cir. 1984).

154. See 17 U.S.C. $\$ 202$ (1994) (Copyright Act); U.C.C. $\$ 2 B-501$ (b) (Annual Meeting Draft, July 24-31, 1998).

155. See U.C.C. $\$ 2$ B-501(c) (Annual Meeting Draft, July 24-31, 1998) (providing that title to a copy is determined by the contract).

156. See id. \$ 2B-501(a) (governing timing of transfer of rights).

157. See supra text accompanying notes 149-153. 
was created by the earlier version of section $2 \mathrm{~B}-502(2)$, which made transfers of all nonexclusive licenses ineffective, except in special circumstances-including, most importantly, the consent of the licensor..$^{158}$ This provision was said to be required by federal intellectual property policy as evinced by two cases, ${ }^{159}$ Everex Systems, Inc. v. Cadrak Corp. ${ }^{160}$ a patent case, and Harris v. Emus Records Corp. ${ }^{161}$ a copyright case. Everex reasoned that a restraint on transfers is necessary to prevent nonexclusive licensees from undermining "the reward that encourages invention." 162 According to the court, free assignability would mean that "every licensee would become a potential competitor with the licensorpatent holder in the market for licenses under the patent." tion, the licensor would lose "the very inportant ability to control the identity of its licensees," leading to the possibility that a license to a small firm in a remote market would give way to a serious competitor, who makes heavy use of the technology in the licensor's own markets. ${ }^{164}$ Harris reasoned similarly, largely taking its cues from patent cases, but adding the reasoming that transfers of nonexclusive licenses would interfere with the licensor's ability to monitor licensed uses. ${ }^{165}$

One could question whether the drafters were right to rely so heavily on the less-than-compelling reasoning advanced by these two circuit courts. ${ }^{166}$ The Everex court failed to distinguish between a right to transfer a license and a right to grant unlimited sublicenses. While it is true that a licensee's right to sublicense would increase the players in the licensing market and lead to more competition than the licensor might wish, the right to transfer a license does not pose the same danger. It merely allows the licensee to replace itself with a different licensee-it enables licensees to sell their businesses, spin off divisions, and merge, all without losing the valuable benefits of the license. The licensor is not necessarily affected. It is not put into significant competition with licensees in the license market because the licensee has only one license to sell; nor does the licensor have any more licensees to monitor than it did before. Of course, competition in the product market could mcrease, but if that were a concern, it would also be a concern about the original licensee (who could, after all, expand to become a serious competitor after the license agreement was made). A licensor worried about

\footnotetext{
158. See, e.g., U.C.C. \$ 2B-502(2) (Draft, Mar. 1998).

159. See id. § 2B-502 reporter's note 3 .

160. 89 F.3d 673 (9th Cir. 1996).

161. 734 F.2d 1329 (9th Cir. 1985).

162. 89 F.3d at 679 (quoted in U.C.C. § 2B-502 reporter's note 3 (Draft, Mar. 1998)).

163. Id.

164. Id.

165. See 734 F.2d at 1333.

166. See U.C.C. § 2B-502 reporter's note 3 (Draft, Mar. 1998).
} 
competition from licensees-or, as in Harris, about monitoring the licensees - has many options: it can bargain for limits on the number of uses and on the kinds of use, and for geographic restrictions; it can condition the license on a right to inspect. So long as these limits run with the license, the licensor would be in no worse position after the transfer than it was before. Ironically, Article $2 \mathrm{~B}$ makes it considerably easier to impose such restrictions, to assure their transfer, ${ }^{167}$ and, in some instances, to enforce them through self-help remedies. ${ }^{168}$ Everex and Harris did not consider the facilitation provided by Article $2 \mathrm{~B}$ because it was not in effect at the time of the decisions. However, any time that section $2 \mathrm{~B}-502$ is applicable, the rest of Article $2 \mathrm{~B}$ will be as well; the drafters should have considered the full panoply of protections in evaluating - and then determining - the effect of transfers on licensors. ${ }^{169}$

Moreover, one could argue that even if all of the dangers envisioned by Everex and Harris are present, the loss they envision in the value of intellectual property may not offset the cost of making licenses non-transferable. If licensees lose flexibility in their business arrangements, they will not be willing to pay as much to license technology, thereby decreasing the rewards available to the licensor (and, therefore, to the original creator). More important, one of the benefits of an exclusive right is that it can be used to attract capital both to finance the development of the invention and to finance the exploitation of the invention. Despite the drafters' attempts to protect financiers, ${ }^{170}$ the limit on transfer threatens capital accumulation for the commercialization phase, which is a serious problem. The costs of cominercializationdeveloping a marketable version of the product or process, establishing distribution channels, and conducting market research-can be as expensive as inventing. These activities are also equally important to bringing new technologies to end users, which, in the final analysis, is a inain goal of intellectual property law. ${ }^{171}$

167. See U.C.C. $\$ \S 2 B-309,2 B-503$ (Annual Meeting Draft, July 24-31, 1998).

168. See id. §§ 2B-310, 2B-715(b).

169. Arguably, section $2 \mathrm{~B}-502$ is not applicable to transfers of intellectual property rights that are incidental to the sale of assets. The November 1, 1997 Draft included an example that indicated clearly that it was applicable. See U.C.C. § 2B-708 reporter's note 4, illus. 4 (Draft, Nov. 1, 1997) (considering the sale of a plant containing robotics software and noting that the license to use the robotics is nontransferable). Later drafts omit that example.

170. See, e.g., U.C.C. \$§ 2B-503(b), 504, 715 (Annual Meeting Draft, July 24-31, 1998) (enabling the creation of security interests in any right that can be transferred); see also id. § 2B-619 (setting the relative rights of the parties in financial accommodation contracts).

171. The drafters' failure to fully consider the effect of this restriction on the creator's ability to extract value from the work is symptomatic of the problem noted earlier, that upstream issues are largely discounted. 
There is also a question whether the drafters, Everex, and Harris are even right that federal policy is relevant to this issue. Everex rejected an approach ${ }^{172}$ suggested by Justice Traynor in Farmland Irrigation Co. $v$. Dopplmaier. ${ }^{173}$ Justice Traynor had reasoned from the fact that federal patent laws do not govern assignments of licenses and the fact that licensing issues do not "arise under" federal law for federal jurisdiction purposes, to the conclusion that states are free to adopt their own policies about licensing. ${ }^{174}$

Finally, it is worth noting that the adoption of the Everex/Harris approach ineant that considerable work was required to create a way for licensees to use their rights as security for loans. Indeed, the rest of the section on transfers dealt mainly with that problem. Thus, subsequent sections differentiated between creating a security interest and enforcing the interest; creation was possible, but enforcement depended on the legal restrictions imposed by section $2 \mathrm{~B}-502$ and by any contractual restrictions that are enforceable under section 2B-503. ${ }^{175}$ This result, however, could still inhibit lending. Among other things, it made enforcement depend on the licensor. For trade secret holders, this result was especially galling because even if federal policy were relevant to licensing federal rights, and even if the drafters were right about Everex and Harris, the policy would not bear directly on trade secret licenses. Trade secrets are purely creatures of state law..$^{176}$

The 1998 Annual Meeting Draft of Article 2B overhauls these provisions. Section 2B-502(1) now states a default rule of free transferability, subject to a few exceptions. The first applies to transfers that are prohibited by federal law. Neither Everex nor Harris is cited in the reporter's notes to this provision, which could lead one to conclude that courts will now be left free to determine federal law for themselves-to weigh the above arguinents and come to their own conclusions, just as Article 2B leaves courts to determine other federal limits on contractual freedom for themselves. Unfortunately, however, the drafters are not

172. See Everex Sys., Inc. v. Cadrak Corp., 89 F.3d at 677-78, 678 n.4.

173. 308 P.2d 732 (Cal. 1957).

174. See id. at 218; see also T.B. Harms Co. v. Eliscu, 339 F.3d 823 (2d Cir. 1964). T.B. Harms Co. held that

an action "arises under" the Copyright Act if and only if the complaint is for a remedy expressly granted by the Act, e.g., a suit for infringement..., or asserts a claim requiring construction of the Act...., or, at the very least and perhaps more doubtfully, presents a case where a distinctive policy of the Act requires that federal principles control the disposition of the claim. The general interest that copyrights, like all other forms of Id. at 828 . property, should be enjoyed by their true owner is not enough to ineet this last test.

175. See, e.g., U.C.C. § 2B-503, 2B-504 (Draft, Mar. 1998).

176. Cf. id. $\$ 2 \mathrm{~B}-507$ reporter's note 1 (noting that priority rules regarding trade secrets are not influenced by federal law, but not explaining why, to a large extent, the same rules apply nonetheless). 
quite so willing to take the neutral position that they take on publicregarding aspects of federal law here: the reporter's notes to section 2B-503 on financier's interests in a license still cite Everex (Harris is now replaced by a different copyright case, one that relies for its policy discussion on Everex). ${ }^{177}$ Furthermore, section 2B-503 perpetuates the distinction between the creation and enforcement of a security interest. However, since the inhibition on lending will now apply only when federal law prohibits transfer, trade secret holders may be in a better position under this draft than they were under prior ones. Of course, courts that find the reasoning in Everex compelling could apply its prohibitions on transfer to trade secrecy licenses as a matter of state common law. But hopefully, they will instead take the drafters' decision to remove trade secrets from the ambit of the Everex rule as a signal that this rule should not be further extended. ${ }^{178}$

This resolution of the Everex problem does not, however, mean clear sailing for the transfer of trade secret licenses. Other exceptions to the free-transferability rule clearly do apply to trade secrets. Section 2B502(1)(B), for example, makes a contractual interest nontransferable if the transfer

would materially change the duty of the other party, materially increase the burden or risk imposed on the other party, disclose or threaten to disclose the other party's trade secrets, confidential information or information that is subject to an enforceable non-disclosure agreement, or materially impair the other party's property or its likelihood or expectation of obtaining return performance. ${ }^{179}$

The reporter's notes to section 2B-502 do not offer very much by way of example or illustration; if taken literally, these provisos could have many of the same effects as the Everex rule. Indeed, the language on transfers that "disclose or threaten to disclose" a trade secret is especially draconian. It reads as if no transfer is possible if there is any disclosure of a trade secret, making it difficult to see how a trade secret could ever be transferred, including through the buy-out, merger, or spin-off of the licensee. As a result, to the extent licensee firms and their creditors consider a firm's licenses a part of that firm's enterprise value,

177. See U.C.C. § 2B-503 reporter's note 2 (Annual Meeting Draft, July 24-31, 1998). The new copyright case is In re Patient Education Media, Inc., 210 B.R. 237 (Bankr. S.D.N.Y. 1997). The relevant discussion is at 210 B.R. at 242.

178. As to copyrights, a better approach would be to distinguish sublicenses and transfers. Because there clearly are problems that can arise from unlimited rights to sublicense, courts applying section 2B-502(1) should follow Everex for sublicenses, but permit other transfers so long as they effectively impose on the transferee any contractual limitations that were imposed on the transferor, or require the transferor to warrant that promises of confidentiality will be maintained.

179. U.C.C. $\$ 2$ B-502(1)(B) (Annual Meeting Draft, July 24-31, 1998). 
that value will be reduced. ${ }^{180}$ This is especially true in light of recent case law which has laid out a rather expansive concept of threatened disclosure. ${ }^{181}$

In earlier drafts, a reporter's note ameliorated the problem somewhat by making it clear that section $2 \mathrm{~B}-502$ was addressed not to the absolute risk of disclosure, but to the relative risk-meaning that so long as the secret in the transferee's hands is as safe as it was in the transferor's hands, transfer is possible (absent other considerations). ${ }^{182}$ That note has been removed, perhaps because the drafters are now relying on the language of the new text, where the adverb "materially" could be read to apply to the phrase that begins with the word "disclose." However, that reading is dubious: "Inaterially" appears in two other phrases, which suggests that it is not meant to modify the "disclose" phrase. The result of the omission of this note, coupled with the ambiguity in the statutory language, is an uncertainty that is a drag on value in itself.

Similar remarks can be made about the prohibition on transferring interests when the transfer will materially impair the other party's property. Here, the notes supply an example of a small company (ABC) that transfers its license to a large company (AT\&T), which now utilizes the information product much more than $\mathrm{ABC}$ did. ${ }^{183}$ According to the note, the licensor's imterest will not be sufficiently protected by the procedure suggested im connection with Everex - that is, the imposition of a contractual restriction on use. A restriction on use would only allow the licensor to sue for breach of contract, which would create "a significant period in which the transferee would be protected by the license before it could be canceled in litigation against the licensee." 184 In contrast, a rule against transfer would preclude the licensee from competing with the licensor.

It is difficult to understand this reasoning. Once again, the restriction on transfer is also a drain on the licensor's rights. As in Everex, it means that licensees will not be willing to pay as much for their licenses

180. That is, licenses would not play a part in the component of the enterprise value that is attributable to the alienability of the licenses that the firm holds. Licenses, of course, would still contribute to production values. The March 1998 Draft gave an explicit example of this problem. See U.C.C. $\$ 2 B-504$ reporter's note 6, illus. 2 (Draft, Mar. 1998) (showing that enforcement of a security interest in a license would be barred if the enforcement involved a transfer that threatened trade secret rights).

181. See, e.g., Novell Inc. v. Timpanogos Research Group, Inc., 46 U.S.P.Q.2d 1197, 1217 (Utah Dist. Ct. 1998) (finding that use of information to avoid going down blind alleys is actionable under Utah's version of the Umiform Trade Secret Act); see also PepsiCo, Inc. v. Redmond, 54 F.3d 1262, 1268 (7th Cir. 1995) (setting out the concept of "mevitable disclosure").

182. See U.C.C. \& 2B-501 reporter's note 2 (Draft, Mar. 1998).

183. See U.C.C. § 2B-502 reporter's note 7 (Annual Meeting Draft, July 24-31, 1998).

184. Id. 
as are licensees who can transfer their interests. The issue, then, is whether this impairment is less than the impairment that results from transfers like the one from ABC to AT\&T. Although the drafters are right that it will take some time to pursue a breach of contract case, they fail to consider that copyright infringement actions take a while to litigate as well. Given the uncertainty as to which impairment is worse, the better default rule is probably free transferability. Licensors can always bargain for more restrictive provisions if they disagree with this analysis. Customized, negotiated provisions will allow licensors to spell out more clearly than could section 2B-502 exactly how to determine which impairments should be regarded as material.

\section{Performance}

The drafters of Article $2 \mathrm{~B}$ make a key contribution to information contract law in part 6 , which creates a nuanced system to deal with performance issues. Article $2 \mathrm{~B}$ recognizes two crucial facts about information products: they are difficult to return and sometimes require perfecting. As to return, the basic rule, section $2 \mathrm{~B}-601$, differentiates between a breach and a material breach: only the latter provides a basis for avoiding the contract. ${ }^{185}$ Article $2 \mathrm{~B}$ gives acquirers of information the right to inspect copies before payment and then to refuse performance if there is a material breach, and even to revoke acceptance in certain circumstances, ${ }^{186}$ although that right is attenuated when the inspection would reveal trade secrets. ${ }^{187}$ Moreover, these rights are not available in situations where the licensee will receive substantially the full value of the performance upon its receipt. ${ }^{188}$

Similarly, section 2B-603 covers agreements that require one party to submit products that meet the satisfaction of the other, and gives parties an opportunity to work out "bugs" without either side losing the benefit of the contract. ${ }^{189}$

Provisions in sections $2 \mathrm{~B}-612$ and $2 \mathrm{~B}-614$, dealing with refusal and revocation of acceptance, are also helpful. Given Article 2B's goal of enabling intellectual property owners to tailor licenses to maximize value, it is no surprise that the part on performance is very careful to protect restrictions that licensors impose on use and promises of confidentiality that they extract. Refusals and revocations of acceptance are subject to obligations of confidentiality and use restrictions, ${ }^{190}$ and

185. See id. $\$ 2 \mathrm{~B}-601$ reporter's note 3 .

186. See id. $\S \S 2 \mathrm{~B}-608,2 \mathrm{~B}-609,2 \mathrm{~B}-614$. Under sections $2 \mathrm{~B}-604,2 \mathrm{~B}-605$, and $2 \mathrm{~B}-609$ (c), the licensor may have a right to cure.

187. See id. \& 2B-608(c)(4).

188. See id. § 2B-604.

189. See id. § 2B-603(2); see also id. § 2B-614 reporter's note 2.

190. See, e.g., id. §§ 2B-612(1), (5), 2B-614(d). 
Article 2B makes clear that access contracts are subject to all restrictions in the contract as well as restrictions imposed by intellectual property law and "other applicable law."191 Furthermore, restrictions transfer down the distribution chain, so that end users effectively are bound by restrictions imposed by entities with which they had no dealings. ${ }^{192} \mathrm{Fi}$ nally, confidentiality obligations and use restrictions survive the termination of the agreeinent. ${ }^{193}$

There are, however, a few situations in which another unique characteristic of information should have been considered inore fully. These situations involve the problem of monitoring unauthorized uses. As noted earlier, section 2B-604 limits rights to acceptance and to revocation in situations where exposure alone transfers significant value. But the reporter's note confusingly uses the term "informational content," 194 which, as we have seen, refers to material that can be perceived in ordinary use. ${ }^{195}$ In some instances, however, exposure allows the recipient to learn inore, and even to reverse engineer the product; if the ain is to prevent unauthorized uses of such information, the language should be revised. ${ }^{196}$

Section 2B-623, the provision that allocates the risk of loss during the physical transfer of copies, appears to neglect another problein unique to trade secrets: it allocates only the risk of incurring the expense of replacing lost copies, not the consequences that can flow from trade secret exposure. For federal copyright and patent rights, the risk allocations made in the draft are the only ones that are necessary because the loss of a copy is, essentially, the only financial risk that either party bears during a transfer. (Although someone could find the copy and use it, the royalty payment flowing from that use could be clained via a copyright infringement action; the copyright itself will reinain valid.) For trade secrets, however, losing a copy could spell the end of the right because if the secret becoines generally known, the right will be unenforceable. Perhaps the section does mean to allocate the risk of destroying the trade secret right, but if it does, it should certainly say so explicitly. This problem recurs in Article 2B's treatment of remedies, to which I now turn.

191. Id. § 2B-615(a)(2).

192. See id. \& 2B-617. Restricted licenses may be subject to the refund right. See, e.g., id. $\S 2 \mathrm{~B}-$ 617 reporter's note 2 (c) \& illus. 1.

193. See id. § 2B-625(b); see also id. § 2B-702 (c)(3) (providing that certain obligations continue after cancellation).

194. Id. § $2 \mathrm{~B}-604$ reporter's note.

195. See id. § 2B-102(a)(26); see also supra discussion accompanying notes 56-67.

196. This is not to say that this goal is a good one. See supra text accoinpanying notes 131-134. 


\section{Remedies}

\section{a. Article $2 B$ Remedies Generally}

As with the materials on financier's interests, the drafters did yeomen's work plowing their way through the remedy principles of the U.C.C. and intellectual property policy. On the whole, their labor was successful. The general rule is that remedies are cumulative and chosen by the aggrieved party, but there can be no double recovery on the same injury. ${ }^{197}$ Because the demand for relief can include both intellectual property and contract remedies, Article $2 \mathrm{~B}$ protects the goals of both regimes. For example, a copyright holder whose license was breached can receive damages on account of the lost value of the contract and can also assert that the post-breach uses of the copyrighted materials constituted copyright infringement. ${ }^{198}$

As with other parts of Article 2B, the details of this seventh part largely mirror the principles set forth in Article 2, with modifications reflecting the reality that unique qualities of information products require different results. Thus, the nonreturnability of information is dealt with by requiring even aggrieved parties to continue to comply with contractual use restrictions. ${ }^{199}$ Because the value of information products cannot always be objectively determined, and does not usually reside in physical embodiments, the drafters have deemed it inappropriate to determine damages on a resale standard. ${ }^{200}$ The monitoring problem is recogmized by engrafting a discovery rule onto the statute of limitations. ${ }^{201}$ Lastly, Article 2B's limitation on consequential damages for published information content is sensitive to the expressive implications of these works. ${ }^{202}$

197. See, e.g., U.C.C. $\S \S 2 \mathrm{~B}-701(\mathrm{a}), 2 \mathrm{~B}-707(\mathrm{a}), 2 \mathrm{~B}-708$ reporter's note 5 (Annual Meeting Draft, July 24-31, 1998).

198. Federal courts have occasionally flirted with an election-of-remedy idea in intellectual property cases. If such a rule were adopted, this provision might be preempted, at least to the extent that it allows cumulation of federal remedies. However, the better view is the one adopted by the drafters. Cf. In re Yardley, 493 F.2d 1389, 1395 (C.C.P.A. 1974) (rejecting the election doctrine in the context of a design patent application on a copyrighted work).

199. See U.C.C. § 2B-701(c) (Annual Meeting Draft, July 24-31, 1998); see also id. § 2B715 (a)(2) (giving aggrieved parties the right to prevent the continued exercise of rights). Section $2 \mathrm{~B}$ 715(e) himits this right to prevent continued use in cases in which the information's authorized use rendered it unidentifiable. Section 2B-715 also takes up the question of judicial enforcement; subsection $2 \mathrm{~B}-715$ (f) gives licensees the same rights as licensors with respect to information that the licensee furnished. Subsections $2 \mathrm{~B}-715$ (b) and (c) provide for judicial enforcement, including a right to prejudgment relief.

200. See id. § 2B-708 reporter's notes 2, 3. Article 2B, however, does retain Article 2's approach to cover. See id. $\$ 2 \mathrm{~B}-709$ reporter's note 1.

201. See id. \$ 2B-705(c).

202. See id. \$ 2B-707(d), 2B-707 reporter's note 4. 


\section{b. Article 2B's Trade Secret Remedies Specifically \\ i. Monetary Damages}

That said, Article 2B's treatment of trade secret remedies could benefit from additional attention. Although Article 2B recogmizes that reliance on "formula-driven damage computation" will often be inappropriate in cases involving information products, ${ }^{203}$ it, nonetheless, retains three core limits on damages: (1) parties must not be put in a substantially better position than they would have been in had performance occurred; ${ }^{204}$ (2) liquidated dainages must be reasonable in light of the loss; ${ }^{205}$ and (3) awards should not be overly speculative. ${ }^{206}$ These principles are relatively easy to apply im cases involving federal rights. Copyright and patent licensing information is often public, giving courts a sound basis on which to calculate market value. Courts may have a harder time in trade secret cases, however, where the details, including the royalty provisions, of licenses are sometimes themselves secret. Further, courts have long struggled with the question of calculatimg the income stream of trade secrets because they do not have a fixed term. The current thinking is that courts should take as the tern the time that it would have taken for the information to be imdependently discovered or reverse engineered, but that determination is only an educated guess. ${ }^{207}$ Without more guidance, courts inay be overly conservative in order both to avoid speculation and to make sure that the trade secret holder does not wind up in a substantially better position because of the breach. ${ }^{208}$

Another problem is that Article $2 \mathrm{~B}$ is not entirely clear on how to treat claims arising from the breach of a duty of confidentiality. In such cases, the trade secret holder is mjured by the use of the information by the breaching licensee as well as by anyone who learned the information froin that licensee. In addition, if the disclosure is considered

\footnotetext{
203. Id. $\S 2 \mathrm{~B}-707$ reporter's note 1.

204. See id. § 2B-701(b), 2B-701 reporter's note 3.

205. See id. § 2B-704(a).

206. See id. § 2B-707(d)(2), 2B-707 reporter's note 1 .

207. See, e.g., Jet Spray Cooler, Inc. v. Crampton, 385 N.E.2d 1349, 1364 (Mass. 1979) (Kaplan, J., concurring) (arguing damages should depend on duration of secrecy). See also Goldstein, supra note 117 , at $123-27$.

208. Because not every state tolls the statute of limitations until the loss should have been discovered, Article 2B inay be the source for a reinedy in states where the breach is not discovered quickly. In those states, these limits on a court's ability to order uncertain rehef could be a problein. See, for example, Computer Associates International, Inc. v. Altai, Inc., 61 F.3d 6, 7-8 (2d Cir. 1995), conforming to answer to certified question at 918 S.W.2d 453 (Tex. 1994), in which the claim of a trade secret holder who did not discover appropriation until after the statute of limitations expired was dismissed as time-barred. A related case, Computer Associates International, Inc. v. Altai, Inc., 126 F.3d 365 (2d Cir. 1997), is noted at U.C.C. $\$ \S 2 B-105$ reporters' note 3, 2B-208 reporter's note 6. This was a subsequent case between the same parties, which was decided on the basis that the case reported at 61 F.3d 6 was res judicata.
} 
widespread, the information may no longer be deemed secret, thereby mvalidating the licensor's ability to extract benefits from any other users (including other licensees). Section 2B-707(a) states a broad rule allowing parties to recover direct, incidental, and consequential damages. ${ }^{209}$ Section $2 B-707(b)$ adds that

[t]he remedy for breach of contract relating to disclosure or misuse of information that is a trade secret or in which the aggrieved party has a right of confidentiality may include as consequential damages compensation for the benefit received by the party in breach as a result of the breach. ${ }^{210}$

The reporter's notes consider the problem of losing royalties from the breaching licensee or from those to whom the breacher revealed the information, but they do not deal specifically with the problem of invalidating the trade secret. ${ }^{211}$ Does this mean that section 2B-707(b) is imtended to limit Article $2 \mathrm{~B}$ remedies to the value to the breacher? The definition of consequential damages indicates that the concept includes "lost value of a trade secret dues [sic] to wrongful disclosure,"212 but further clarification would be useful..$^{213}$

\section{ii. Specific Performance}

Specific performance is available when the trade secret license expressly so provides, and also in non-personal service contracts where the "performance is unique."214 Trade secrets, almost by definition, involve unique performance. Ironically, they also present situations where ordering specific performance is usually inappropriate. Examples include situations in which performance was withheld because the licensor was concerned about a general release of the secret (and invalidation of the trade secret right under state law), as well as cases in which requiring performance would inupinge upon the licensor's First Amendment right not to speak. There may also be situations that fall short of impossibility, but where the licensor cannot develop the information for which the

209. See U.C.C. § 2B-707(a) (Annual Meeting Draft, July 24-31, 1998).

210. Id. \& 2B-707(b).

211. Section 2B-708 reporter's note 3 states that consequential damages for breaches of disclosure restrictions are appropriate, but the examples do not include the losses that flow from the invalidation of a trade secret. Section 2B-708 reporter's note 4 gives examples of damages recoverable under trade secret law, but again this problem is not mentioned.

212. U.C.C. \& 2B-102 reporter's note 7 (Annual Meeting Draft, July 24-31, 1998).

213. More guidance would be useful also on the somewhat opposite problem: how should relief be calculated when a promise of confidentiality was breached but the information was already publie? Courts may be unwilling to entertain claims to enforce agreements related to the use of public information. Accordingly, relief might be nominal, unless the iuformation became public as a direct result of the breach. This appears to be the right approach under trade seerecy law; it would therefore be helpful if the drafters inade it clear that Article 2B does not change the result. See also id. \& 2B-309 reporter's note 2 .

214. Id. \& 2B-711(a)(2). 
licensee contracted (or where it could not be developed or delivered with the secrecy required). The reporter's notes indicate that at common law, specific performance of intangibles contracts is disfavored, but the drafters do not explain why they suggest altering this presumption. ${ }^{215}$ Similarly, they emphasize that the provision gives courts discretion to shape decrees in a manner that protects intellectual property rights, but they do not deal with expressive concerns or explain what a court should do if it finds that the licensor's risk cannot be eliminated. ${ }^{216}$

\section{iii. Liquidated Damages}

Finally, the draft validates liquidated damages provisions ${ }^{217}$ and gives licensors the ability to preclude cancellation. ${ }^{218}$ In the context of patent licenses, such provisions may conflict with patent policy, which is leery of any attempt to reduce a licensee's incentive to challenge patent validity. The theory is that the public interest is best served if licensees serve as private attorneys general who patrol the validity of patents for the benefit of the public domain. ${ }^{219}$ There are strong arguments to be made against that position, ${ }^{220}$ and the principle does not, in any event, apply directly to trade secrecy cases, where there is no federal right to patrol. Nonetheless, there may be instances where, in the absence of the obligation to continue to pay damages, a trade secret licensee would find it in its mterest to breach the contract and claim the right unenforceable. Because that action would also benefit the public domain, those who believe that the patent policy is correct may have difficulty with these provisions as well. In the context of liquidated damages, the drafters state that "if the parties negotiate the clause, that clause is per se reasonable."221 That is not, however, everyone's view in regard to intellectual property licenses: a licensee and a licensor's interests can

215. See id. § $2 \mathrm{~B}-711$ reporter's note 2 .

216. See id. § 2B-711(b), 2B-711 reporter's note 3. This provision contrasts rather sharply with the position that Article $2 \mathrm{~B}$ takes on allowing sublicensing, according to which the licensor's ability to protect similar interests was considered paramount to other important considerations. See supra text accoinpanying notes 158-165. Some of what is said in that context may also apply to soine applications of section $2 \mathrm{~B}-713$, which gives aggrieved licensees a riglit to continue to use imformation under a contract.

217. See id. § 2B-704; see also id. § 2B-701(b) (excepting liquidated damages provisions from rule allowing court to limit remedy, if remedy would put party in better position than performance would have).

218. See id. \& 2B-702(c).

219. See, e.g., Lear, Inc. v. Adkins, 395 U.S. 653, 670-71 (1969); Patent Law Revision: Hearings on S. 643, S. 1253 \& S. 1255 Before the Subcomm. on Patents, Trademarks, and Copyrights of the Senate Comm. on the Judiciary, 92d Cong. 188-89 (1971) (statement of Raymond E. Johnson, General Counsel, Electronic Industries Ass'n).

220. See Dreyfuss, supra note 75.

221. U.C.C. § 2B-704 reporter's note 1 . 
sometimes be aligned with one another-and yet their interests can be distinctly antithetical to the interest of the public.

\section{II}

Article 2B and National Innovation Policy: Article 2B's INTERSECTION WITH FEDERAL AND STATE LAW AND Policy

Now that the specifics of Article $2 \mathrm{~B}$ have been analyzed in varying degrees of detail, the next Part of this Article looks at the drafters' efforts as a whole. After examining Article 2B's relationship to federal policy, I say a word about state law. As suggested earlier, there are apparently serious differences between what Article $2 \mathrm{~B}$ does and what national laws seem to permit. But there are, perhaps, fewer real disagreements. Article 2B facilitates private arrangements in a very new way, and, for the first time, provides the next century's innovators with reliable mechanisms for earning a return from those who value their work. Since neither federal nor state law bas yet grappled with this sort of effort, it is not possible to say for sure how Article 2B will be implemented or how its relationship to innovation policy will be evaluated. Nonetheless, the drafters have been less than helpful in assuring that it will be viewed favorably. In the last Section of this Part, I suggest ways in which they-or perhaps the ALI-could help the cause.

\section{A. Article $2 B$ and Federal Law and Policy}

The first task in measuring Article $2 \mathrm{~B}$ against federal policy is a rather big one: deciding exactly what federal policy is. It is, after all, difficult to comment on issues of consistency without knowing what Article 2B must be consistent with. Unfortunately, as observers of the trade secrecy scene know well, the extent to which federal innovation law tolerates state action is not easily defined. Congress took a stab at the preemption problem in the 1976 Copyright Act, but the analysis it provided was rather truncated. ${ }^{222}$ The Act treats federal interests regarding copyrightable material, but it does not cover federal policy on the patent side, or deal with conflicts preemption, or take on the broader concerns that flow from constitutional limits on government activity in this area. ${ }^{223}$ The lower courts have not had an easy time with the issue.

222. Under 17 U.S.C. $\$ 301$ (1994), a state law is preempted if it covers the type of work that is the subjeet matter of copyright law or if it creates rights equivalent to those that are within the general scope of copyright.

223. That is, limits on Congress' constitutional power over intellectual property rights, see U.S. Const. art I, § 8. See generally Rochelle COOPER DREyfuss \& RoberTa Rosenthal Kwall, Intellectual Property: Cases and Materials on Trademark, Copyright, and Patent LAW 519-23, 546-47 (1996). 
Tests for statutory preemption proliferate, and the cases are in substantial disagreement. ${ }^{224}$

Much of the law on preemption, therefore, comes from the Supreme Court. But the Court has not done much better than Congress or the lower courts in defining the scope of preemption. The trilogy of cases on the protection of works of "low authorship," Kewanee Oil Co. v. Bicron Oil Corp. ${ }^{225}$ Bonito Boats, Inc. v. Thunder Craft Boats, Inc., ${ }^{226}$ and Feist Publications, Inc. v. Rural Telephone Service Co., ${ }^{227}$ do not produce a clear message. ${ }^{228}$ In Kewanee, the Supreme Court held it consistent with federal patent policy to enforce a state-law-based duty of confidentiality, even though the result was that a group of former employees were enjoined frown utilizing information (a method for growing crystals) that was not patented. Bonito Boats, on the other hand, held as unenforceable a state statute that restricted the use of a subpatentable technology (using a boat hull as a mold). Similarly, the Feist Court held that under the Constitution and the Copyright Act, a pedestrian compilation of facts (a telephone book) was not protectable subject matter. ${ }^{229}$

One way to make sense of these cases is to say that Feist and Bonito Boats overruled Kewanee, and that states are disabled froin recognizing enforceable claims of exclusivity with respect to non-federally protected intellectual property. Of course, if this is the law, Article $2 B$ is simply untenable. The obligations of confidentiality and restrictions on use supported by Article $2 \mathrm{~B}$ are preempted when these obligations reduce public access to information that is neither patented nor copyrighted. ${ }^{230}$

224. For examples of the statutory analysis under 17 U.S.C. $\S 301$, see National Basketball Association v. Motorola, Inc., 105 F.3d 841, 844-54 (2d Cir. 1997) and Baltimore Orioles, Inc. v. Major League Baseball Players Association, 805 F.2d 663, 674-79 (7th Cir. 1986). On conflicts preemption, see Vault Corp. v. Quaid Software Limited, 847 F.2d 255 (5th Cir. 1988). Vault held that a state statute permitting software producers to prohibit decompilation and adaptation conflicted with 17 U.S.C. $\$ 117$, which permits owners of copies of software to make archival copies. See id. at 261-68. Because Vault involved a use restriction, it contrasts nicely with ProCD, Inc. v. Zeidenberg, 86 F.3d 1447 (7th Cir. 1996), discussed infra in the text accompanying notes 275-279.

225. 416 U.S. 470 (1974).

226. 489 U.S. 141 (1989).

227. 499 U.S. 340 (1991).

228. Professor Jane Ginsburg comed the term "low authorship" for such works. See Jane C. Ginsburg, Creation and Commercial Value: Copyright Protection of Works of Information, 90 Colum. L. Rev. 1865, 1866 (1990).

229. The Supreme Court also spoke to the issue of state preemption in Goldstein v. California, 41 U.S. 546 (1973), il which it upheld a California criminal statute outlawing the unauthorized duphication of sound recordings. The Court's opinion rehed heavily upon the notion that states ought to be allowed to protect their own industries. See id. at 556-58. Bonito Boats, however, marks a substantial retreat from that position and Goldstein is not, in any event, relevant to uniform legislation.

230. See, e.g., U.C.C. $\S \S 2 \mathrm{~B}-202(\mathrm{e}), 2 \mathrm{~B}-307(\mathrm{~b}), 2 \mathrm{~B}-309$ (c), 2B-612(3), 2B-614(c), 2B-615, 2B617, 2B-625(b), 2B-701(c), 2B-702(c), 2B-707(b) (Annual Meeting Draft, July 24-31, 1998); see also id. $\S 2 \mathrm{~B}-310$ (regardimg self-help). 
Most observers, do not, however, take this position. ${ }^{231}$ Instead, Kenawee can be distinguished using two lines of argument, which I call the "secrecy approach" and the "rights distinction approach." The secrecy approach starts with the proposition that Kewanee involved a technology that was not generally known; the subsequent cases involved information products that were in an important sense public-the dimensions of the boat hull in Bonito Boats were accessible to anyone who cared to look at it, and the telephone numbers in Feist were easily knowable facts, arranged prosaically. Under this view, the decisions in Bonito Boats and Feist did not release all subpatentable and subcopyrightable material into the public domain, but simply ensured that any information that reaches the public domain stays there. ${ }^{232}$ Article $2 \mathrm{~B}$ is directed at trade secrets - at information that is not generally known, and so is not in the domain of the public. Accordingly, there is no direct conflict with federaI policy.

The "rights distinction" distinguishes rights against the world from rights against parties in contractual privity with the innovator. Here, it is key to note that Bonito Boats and Feist involved the enforcement of rights against the world: the state statute in Bonito Boats prevented everyone from using a inold to copy a boat hull; if copyrighted, no one could have reproduced the telephone book in Feist without authorization. In contrast, the obligation enforced in Kewanee ran only against those employees who acquired the technology subject to an obligation of secrecy; any other member of the public who learned the crystal growing method was free to use it. Since Article $2 \mathrm{~B}$ is only about contractual rights, it resembles Kewanee more closely than it does Bonito Boats and Feist. Under this view, then, there would be no conflict between its enforcement and federal policy. Unfortunately, neither of these arguments fully can withstand scrutiny.

\section{The Secrecy Approach}

a. Tensions Between the "Secrecy Approach" and Federal Innovation Policy

One major problem with the secrecy approach harkens back to the information/informational content discussion of the previous Part of this Article: Article 2B does more than facilitate the licensing of trade

231. For a spectrum of views on this issue, see, e.g., Douglas Gary Lichtman, The Economics of Innovation: Protecting Unpatentable Goods, 81 MinN. L. Rev. 693 (1997); Thomas G. Field, Jr., Intellectual Property: Some Practical and Legal Fundamentals, 35 IDEA 79 (1994); J.H. Rcichman, Legal Hybrids Between the Patent and Copyright Paradigms, 94 Colum. L. Rev. 2432 (1994); Kelly A. Ryan, Copyright Law: Do State Misappropriation Rights Survive Feist Publications Copyright Laws?, 1992/1993 ANN. SuRv. AM. L. 329 (1993).

232. See Kewanee, 416 U.S. at 484 ("[Mlatter once in the public domain must remain in the public domain" (cited in Bonito Boats, 489 U.S. at 155).). 
secrets. Rather, it permits the imposition of restrictions on the use and possibly on the disclosure of information without regard to whether the information at issue is secret or not. ${ }^{233}$ As a result, the policy protected by Bonito Boats and Feist is undermined: information that is known, or that can be learned from embodiments, becomes the subject of exclusive rights. ${ }^{234}$

For an example of how this facet of Article 2B works, consider Sega Enterprises, Ltd. v. Accolade, Inc., ${ }^{235}$ which concerned the rights of a Sega competitor to utilize the copyrighted software at the interface between Sega's game modules and the consoles on which they play. ${ }^{236}$ These interfaces cannot be learned through ordinary use. They can, however, be perceived through reverse engmeering, which is precisely what Sega's competitor did. ${ }^{237}$ The Sega court held that it was fair use under copyright law for a competitor to decompile Sega's programs and use some of the code. ${ }^{238}$ Since the interface information learned upon decompiling was also not considered a trade secret, this holding allowed the competitor to make games that run on Sega's modulesthat is, to compete with Sega in the game market and drive down prices.

Now consider a hypothetical version of Sega, in which the license arose after the enactment of Article $2 \mathrm{~B}$. The licenses on the game and console could include an enforceable prohibition against undertaking the activities required to figure out the interface: printing out the program in object code, translatimg that imto source code, and such. Without the interfaces, competitors could not compete with Sega without Sega's permission. The net effect of Article $2 B$ is thus to permit producers like Sega to block further innovation in their industry, to reduce competition, and to mamtain high prices for their works. Since the interfaces that produce this effect are either not copyrightable or are fairly used, the result conflicts directly with Feist. Moreover, the prohibition on reverse engineering appears to be exactly contrary to Bonito Boats, which gives specific examples of reverse engineering practices that the states must permit. ${ }^{239}$

233. See, e.g., U.C.C. $\$ \S 2 \mathrm{~B}-309,2 \mathrm{~B}-626,2 \mathrm{~B}-627,2 \mathrm{~B}-707$ (b) (Annual Meeting Draft, July 2431, 1998); see also discussion at supra note 62.

234. To the extent that such information is fixed in a tangible mediun of expression, protection may also be preempted by 17 U.S.C. § 301 (1994).

235. 977 F.2d 1510 (9th Cir. 1992).

236. See id. at 1514 .

237. See id.

238. See id. at 1518.

239. See Bonito Boats, Inc. v Thunder Craft Boats, Inc., 489 U.S. 141, 160 (1989) ("If [the State] may prohibit this particular method of study and recomposition of an unpatented article, we fail to see the principle that would prohibit a State from banning the use of chromatography in the reconstitution of unpatented chemical compounds, or the use of robotics in the duphication of machinery in the public domain."). Cf. Vault Corp. v. Quaid Software Ltd., 847 F.2d 255, 261-68 (5th Cir. 1988) (finding a similar prohibition sanctioned by state law invalid under a conflicts preemption analysis). 
Interestingly, the latest drafts of Article $2 \mathrm{~B}$ acknowledge this tension with existing federal policy. The definition of "informational content" has changed in that it now "does not include instructions used solely to control the interaction of a computer program with other computer programs or with a inachine." ${ }^{240}$ This definitional modification highlights the fact that interfaces are not exactly secret, but it does not prevent licensors froin negotiating contract provisions that bar reverse engineering. However, although two reporter's notes acknowledge that copyright law considers this form of reverse engineering to be fair use, ${ }^{241}$ both also note that federal policy coexists with contract law and that courts must make decisions on a case-by-case basis. Thus, one can easily imagine a state court concluding that a prohibition on reverse engineering is enforceable if bargained for, irrespective of the externalities it generates.

Significant tension also exists between Article 2B and federal policy even in situations that do involve information that is secret-that is, information that was licensed while it was not generally known. ${ }^{242}$ Federal innovation policy does not just protect material already in the public doinain. Rather, in a fundainental way, it ensures the passage of private material into the doinain of the public. Federal innovation policy is, im short, premised on disclosure, on what we might call "leaks" - on the fact that all information, no matter how secret or legally protected, eventually escapes its private constraints.

It is indeed here, where the drafters' concentration on exploitation issues, to the exclusion of "upstreain" (creative) issues, creates significant probleins. By focusing on the statics of exploitation rather than on the dynamics of innovation, they implicitly adopt the view that social welfare is best promoted by allowing innovators to capture as much as they can of the surplus that their works generate.

That view favoring exploitation over innovation ignores the economics of intellectual property protection. First, exclusive rights regimes are not efficient at converting consumer surplus into producer surplus. For some potential purchasers, the price charged by the holder of an exclusive right will be higher than the inarginal benefit that they would enjoy. This group will forego purchase. Unless the system is adjusted to reduce this deadweight social loss, soine of the social resources devoted

240. U.C.C. $\S 2 \mathrm{~B}-102(26)$ (Annual Meeting Draft, July 24-31, 1998); see supra text accompanying notes 58-62.

241. See id. §§ 2B-105 reporter's note 3, 2B-208 reporter's note 6.

242. See Restatement (ThIRD) of UNFAiR COMPETition $\$ 39$ (1995) ("A trade secret is any information that.... is sufficiently valuable and secret to afford an actual or potential economic advantage over others."); UNIF. TRADE SECRETS ACT \& 1(4) (amended 1985), 14 U.L.A. 438 (1990) (defining "trade secret" as information that "derives ... economic value ... from not being generally known" and that is "the subject of efforts that are reasonable ... to maintain its secrecy"). 
to creativity are dissipated. Second, the static model misses what can be called the "offsets quandary." The rewards that are generated through intellectual property rights are beneficial to the innovation process because they inotivate creativity. But, unless inodified, these rewards also have the offsetting effect of increasing the costs that must be borne by those who are motivated-these creators are required to pay higher prices to build on earlier works. Finally, the welfare-enhancing effects of new technologies do not derive solely from increases in productivity in the end-user market, as contemplated by the rights holders. Instead, much of the social benefit derived from innovation comes from spillover effects-collateral innovations and applications to new fields. ${ }^{243}$ Unless there is leakage, these spillover benefits may never accrue. In fact, every one of the exclusive rights regimes is porous, and it is the leaks in each system that allow it to produce the social benefits that these regimes are designed to generate.

At the constitutional level, the leakage premise is instantiated in the Limited Times provision of the Copyright and Patent Clause, which guarantees that every federally-protected invention eventually enters the public domain. ${ }^{244}$ This policy - of not only protecting private rights, but also enriching the public doinain-is implemented in the term limitations of the Copyright and Patent Acts, ${ }^{245}$ and in the inany other features of these acts that pierce holes in the exclusive rights they create. Examples in the current Copyright Act include the fair use provision and compulsory licenses, as well as the requirements that Americans register their copyright before inaintaining infringement actions, and deposit copies of their work in the Library of Congress. ${ }^{246}$ In patent law, inventors who fail to apply for patents within a specified period of time are divested of their right to obtain patents; maintenance fees are set to discourage use of the full term; there are rights to experiment with certain

243. See, e.g., F.M. Scherer \& DAvid Ross, Industrial MARket STRucture AND Economic Performance 46 (1990); Zvi Griliches, R\&D and Productivity: Econometric Results and Measurement Issues, in HANDBOOK OF THE Economics of InNovation AND TECHNOLOGICAL Change 52, 63-74 (Paul Stoneman ed., 1995); David J. Teece, Profiting from Technological Innovation: Implications for Integration, Collaboration, Licensing and Public Policy, 15 RESEARCH PoL'y 285 (1986). Although the terminology used here is relatively recent, recognition of the significance of spillover effects is not. See, e.g., STAFF of SENATE SubComm. ON PATENTs, Trademarks, and Copyrights, Senate Comm. on the Judiciary, 85th Cong., 2d Sess., An Economic Review of the Patent System: Study No. 15 at 76-79 (Comm. Print 1958) (prepared by Fritz Machlup).

244. See U.S. CoNst. art. I, \& 8 ("The Congress shall have Power... To promote the Progress of Scicnce and useful Arts, by securing for limited Times to Authors and Inventors the exclusive Right to their respective Writings and Discoveries ....") (emphasis added).

245. That limitation is codified im the Copyright Act at 17 U.S.C. $\$ 302$ (1994) and in the Patent Act at 35 U.S.C. $\$ \S 154-156$ (1994).

246. See 17 U.S.C. $\S \S 107$ (fair use), 108-120 (other compulsory licenses), 408 and 411 (registration), 407 (deposit) (1994). 
patented medical products; and the specification requirement is designed to produce maximum usage of the underlying insights from the moment the patent issues. ${ }^{247}$ Further, both regimes release the ideas in protected works to the public domain through the idea/expression (or principle/embodiment) dichotomy; they reduce the cost of copies through the first sale doctrine; and they protect incentives to innovate through the doctrine of misuse. ${ }^{248}$ Both regimes create presumptions of validity, but in neither does a right ever become incontestable. ${ }^{249}$

The porous texture of federal law is mirrored in the trade secrecy law that Kewanee held tolerable. Trade secrecy law protects against misappropriation, but misappropriation is carefully defined to exclude reverse engineering or learning the invention through familiarity with its embodiment. ${ }^{250}$ Like copyright law, trade secrecy law does not protect creators against independent inventors. Moreover, it does not create rights against good faith purchasers. Transfers therefore tend to give rise to opportunities for leakage, and after the information becomes generally known, it loses its status as a trade secret and becomes freely available to all.

Once one accepts the proposition that federal innovation policy is premised on leaks, and that trade secrecy law is federally acceptable because it too is leaky, then certain applications of Article $2 \mathrm{~B}$ become very problematic. Admittedly, the language in the 1998 Annual Meeting Draft of Article 2B has toned down significantly. Language concerning bars on disclosure has been softened, making it less clear whether obligations not to disclose public information can be enforced. ${ }^{251}$ The provision on interpreting grants now explicitly instructs courts to consider

247. See 35 U.S.C. $\S \S 102$ (b), (c), (d) (statuiory bars on patentability), 41(b) (maintenance fces), 271(e)(1) (experimental use), 112 (specification), 271(d) (recognizing misuse doctrine) (1994).

248. See, e.g., Baker v. Selden, 101 U.S. 99 (1879) (idea/expression dichotomy in copyright law); Gottschalk v. Benson, 409 U.S. 63 (1972) (principles/embodiment dichotomy). On first sale, see 17 U.S.C. $\$ 109$ (a) (1994) and Adams v. Burke, 84 U.S. (17 Wall.) 453 (1873) (first sale doctrine); see also supra text accompanying notes 49-51. On misuse, see, for example, Zenith Radio Corp. $v$. Hazeline Research, Inc., 395 U.S. 100 (1969) (patents), Hartford-Empire Co. v. United States, 323 U.S. 386 (1945) (same) and Lasercomb America, Inc. v. Reynolds, 911 F.2d 970 (4th Cir. 1990) (copyrights). See generally U.S. Dep'T OF JUSTICE \& Federal TRADE COMm'N, ANTITRUST GUIDELINES FOR THE LICENSING OF INTEllectual Property (1995), reprinted in 4 Trade Reg. Rep. (CCH) I 13,132 (1995) (analyzing the antitrust implications of licensing agreenents).

249. See 17 U.S.C. $\$ 410$ (c) (1994) (extending presumption only for copyrights registered within 5 years of publication); 35 U.S.C. $\S 282$ (1994) (establishing general presumption of validity); compare 15 U.S.C. $\$ 1065$ (1994) (foreclosing certain grounds for contesting validity of trademark after five years' contimuous use).

250. See Restatement (ThIRd) of Unfair Competition $\$ 43$ (1995); Unif. Trade Secrets ACT § 1(2) (amended 1985), 14 U.L.A. 438 (1990).

251. For example, the definition of "informational rights" now talks about rights to control use, not disclosure. Compare U.C.C. \& 2B-102(27) (Annual Meeting Draft, July 24-31, 1998) (defining "imformational rights"), with U.C.C. § 2B-102(26) (Draft, Mar. 1998) (defining "informational property rights"). 
access rights under other applicable law. ${ }^{252}$ Similarly, obligations that survive termination depend, in part, on the mandates of other applicable law. ${ }^{253}$ Nonetheless, this draft still enables licensors to plug many of the holes that were intentionally punched into the exclusive rights regimes. Licensors can, for example, require licensees to refrain from uses that would be considered fair under the Copyright Act and not "improper" under trade secrecy laws. ${ }^{254}$ These obligations can arise at the licensor's say-so. Arguably, they will be measured by the licensor's concept of scope; ${ }^{255}$ some may even be enforced with self-help remedies. ${ }^{256}$ Almost all of the default rules can be varied by contract, so that licensors can extract from licensees agreements that may impact sigmificantly on the level of future innovation, such as promises to assign to them rights to improvements, to forebear searching for new applications or challenging the validity of the rights transferred. ${ }^{257}$ To make matters worse, the proposed statute is very efficient at passing these contractual limitations through to subsequent purchasers.

Also important is the fact that under Article $2 \mathrm{~B}$, creators are inore likely to license, rather than to sell, embodiments of or rights to their works. Others have pointed out this concern in the context of copyrights, but it is especially true for trade secrets. ${ }^{258}$ To see why, consider how the holder of secret information decides whether to license or to sell it. That decision will presumably be inade by comparing the expected return on a sale agamst the expected return from a license. Prior to Article $2 \mathrm{~B}$, calculating the return on licensing would require substantial discounting of the expected royalty stream. First, the cost of negotiating needs to be subtracted. Second, there is the risk that the license will be transferred, but the obligation to keep the information secret will not be. Third, the licensee might be able to shift the locus of operations into a jurisdiction with poor protection for trade secrets. Fourth, there is the risk that the information will be disclosed, the trade secret will be invalidated, and that an action agamst all defaulting licensees will fail. In that

252. See U.C.C. $\$ 2 B-307(b)$ (Annual Meeting Draft, July 24-31, 1998).

253. See id. $\S 2 \mathrm{~B}-625(10)$. In contrast, older versions of section $2 \mathrm{~B}-625$ expressly provided that "an obligation of confidentiality or nondisclosure" survives termination. See, e.g., U.C.C. § 2B625(b)(3) (Draft, Mar. 1998).

254. See, e.g., U.C.C. $\$ \S 2 \mathrm{~B}-102(\mathrm{a})(13), 2 \mathrm{~B}-109$ (a), 2B-202(e), 2B-307(a)-(b), 2B-601(b), (d), 2B-601 reporter's note 3, 2B-612(3), 2B-615(a)(2), 2B-620(a), 2B-625, 2B-701(c), 2B-702(b)(3), 2B-707, 2B-707 reporter's notes 1 \& 3. (Annual Meeting Draft, July 24-31, 1998). In deciding the extent to which these obligations can be enforced, one liopes that courts will consider the extent to which the final version of Article $2 B$ has softened its approach to disclosure.

255. See supra text accoinpanying notes 110-111.

256. See U.C.C. \& 2B-310 (Annual Meeting Draft, July 24-31, 1998).

257. See Lemley, supra note 13, at 1245-46.

258. See Rice, supra note 12 , at $636-40$. 
environment, a one-time lump sum payment (that is, a sale) can be the wiser choice.

The situation changes under Article 2B. If the default rules are set right, the cost of negotiating will decline. It may be easier to impose promises of confidentiality that survive transfer. In any case, Article 2B disfavors transfers, especially when the transfer increases the risk of disclosure. If Article $2 \mathrm{~B}$ enjoys as much popularity as the rest of the U.C.C., the law across the states will be uniform, so there will be no "jurisdictional" risk. Significantly, Article 2B does not appear to provide for laying off the risk of, or getting compensated for, a secret becoming generally known. ${ }^{259}$ Perhaps that is an error, or perhaps it reflects the drafters' assumption that licenses will be enforced even with respect to information that becomes known. In any event, with lower risks, lump sum payınents may not be as favorable as retaining the right to issue licenses. But this tilt toward licensing is not good news for the public domain: sales increase public accessibility in two ways. First, they are free of constramts on reverse engineering, because the buyer may not be obligated to refrain from uses outside a delineated scope. Second, embodiments are not returned to the seller, and their continuing presence (in libraries, in the home, in the workplace) allows others to derive inspiration from thein. ${ }^{260}$

\section{b. Tensions Between the "Secrecy Approach" and Federal Intellectual Property Law}

Article $2 \mathrm{~B}$ is in tension not only with general federal innovation policy, but also with specific provisions of federal intellectual property law. Others have written about conflicts with copyright law. ${ }^{261}$ For trade secrecy, the probleins arise more clearly with patent law, where there are provisions that are inplicitly based on the premise that trade secrets leak. For instance, the first sentence of section 102(g) of the Patent Act

259. But see U.C.C. \& 2B-102 reporter's note 7 (Annual Meeting Draft, July 24-31, 1998). For a fuller discussion, see supra text accompanying notes 211-213.

260. See Rice, supra note 12, at 636-38; cf. Jessica Litman, Copyright Noncompliance (Or Why We Can't “Just Say Yes" to Licensing), 29 N.Y.U. J. INT'L L. \& PoL. 237, 253 (1997) (commenting on the so-called "Green Paper" - the proposals of the Working Group on Intelleetual Property for contracting in the electronic environment, WORKING GROUP ON INTELLECTUAL PROPERTY RIGHTS, INFORMation INFrastructure TASK Force, INTEllectual Property aNd THE National INFORMATION INFRASTRUCTURE: A PRELIMINARY DRAFT OF THE REPORT OF THE WORKING Group on INTEllectual Property Rights (1994)); Diane Leenheer Zimmerman, Copyright in Cyberspace: Don't Throw Out the Public Interest with the Bath Water, 1994 ANN. SuRV. AM. L. 403, 407-412 (same).

Citing the legislative history, Lemley observes that Congress contemplated that copyright holders could contract out of the first sale doctrine. However, he notes that Congress thought that damages would be limited to expectation damages, not copyright remedies. See Lemley, supra note 13, at 1274 \& n.156 (citing H.R. REP. No. 94-1476 (1971), reprinted in 1976 U.S.C.C.A.N. 5659).

261. See Lemley, supra note 13, at 1266; Rice, supra note 12 , at 645 . 
bars a patent when "before the applicant's invention thereof the invention was inade in this country by another who has not abandoned, suppressed, or concealed it."262 Although there is considerable controversy on this point, there are cases holding that someone who exploits the invention in secret has not abandoned, suppressed, or concealed it. As a result, that person can prevent another from patenting that same technology. ${ }^{263}$ The reasoning in these cases is not very illuminating, but the operative assumption is presumably that exploitation of a trade secret eventually releases it to the public. Allowing another to patent the secret would effectively withdraw what was otherwise public back into the domain of the private. That assumption would not be valid if exploitation of trade secrets could occur without a substantial risk of exposure.

Similarly, section 102(b) of the Patent Act prohibits the patenting of an invention that is on sale for more than a year before the patent application is filed. ${ }^{264}$ Courts have held that secret sales, even sales unknown to the applicant, are sufficient to trigger the bar. ${ }^{265}$ But if trade secrets were not inherently leaky, this provision would frustrate the public interest. Without a patent issuing, there would be no specification and, therefore, no way for the public to learn the new technology.

There will also be friction between Article $2 \mathrm{~B}$ and recent federal initiatives in the intellectual property arena. For example, the recently enacted Economic Espionage Act makes misappropriation of trade secrets a crime. ${ }^{266}$ The definition of what constitutes an offense under the Act is soinewhat uncertain and may turn on what states consider unfair coinpetition. ${ }^{267}$ If Article $2 \mathrm{~B}$ creates new norms on issues of use and moves the line between what is considered lawful appropriation and what is thought to be misappropriation, then it will bring inore activity into the criminal realm. The combined effect of the civil remedies

262. 35 U.S.C. $§ 102(\mathrm{~g})(1994)$.

263. See, e.g., Dunlop Holdings Ltd. v. Ram Golf Corp., 524 F.2d 33 (7th Cir. 1975) (then-Judge, now-Justice Stevens); $c f$. International Glass Co. v. United States, 408 F.2d 395, $401-04$ (Ct. Cl. 1969) (finding that there was insufficient use to maimtain $\S 102(\mathrm{~g})$ claim).

264. See 35 U.S.C. § 102(b) (1994).

265. See, e.g., Evans Cooling Sys., Inc. v. General Motors Corp., 125 F.3d 1448, 1452-53 (Fed. Cir. 1997), cert. denied, 118 S. Ct. 1050 (1998); Lorenz v. Colgate-Palmolive-Peet Co., 167 F.2d 423, 426-30 (3d Cir. 1948).

266. The Economic Espionage Act of 1996 punishes one who:

(1) steals, or without authorization appropriates, takes, carries away or conceals, or by fraud, artifice or deception obtains a trade secret;

(2) without authorization copies, duplicates, sketches, draws, photographs, downloads, uploads, aiters, destroys, photocopies, replicates, transmits, delivers, sends, nuails, communicates, or conveys a trade seeret.

18 U.S.C.A. \$§ 1831(a), 1832(b) (West Supp. 1998). This provision also covers attenupts. See id. §§ 1831(a)(4)-(5), 1832(a)(4)-(5). For an example of a prosecution under The Economic Espionage Act of 1996, see United States v. Hsu, 47 U.S.P.Q.2d 1784 (3d Cir. 1998).

267. See James H.A. Pooley et al., Understanding the Economic Espionage Act of 1996, 5 TEX. INTELL. Prop. L.J. 177, 188-89 (1997); Dreyfuss, supra note 6. 
provided by Article $2 \mathrm{~B}$ and the criminal remedies of the Economic Espionage Act could convert trade secrecy law into near-eternal protection, in violation of the Constitution's Limited Times provision. ${ }^{268}$

Moreover, if Article 2B takes effect, the proposal to recognize prior user rights ${ }^{269}$ - that is, a limited right in one who independently invented a technology before another patented it-would become even more controversial than it already is. Now, the main problem with recognizing prior user rights is that the availability of such rights will reduce incentives to apply for patents - the argument being that without the threat that someone else will get a patent and stop prior users from exploiting their own inventions, prior users would prefer to keep their technologies to themselves. The counterargument is that the risk of disclosure is enough to motivate those with patentable technologies to seek federal protection. ${ }^{270}$ Under Article $2 \mathrm{~B}$, the calculus shifts. The inventor deciding whether to patent his mvention or to keep it secret will presumably compare his expected returns, in this case, the net return he would earn from dealing in a trade secret, against the return that he would earn from a patent. Patents are of limited duration, and are much costlier to obtain than trade secrets. In the past, patents have nonetheless been desirable because they obviate the risk of disclosure. Under Article 2B, however, a well-drafted license-one that survives even if the trade secret is revealed-can duplicate the benefits of patenting. With lower up-front costs, and a possibly infinite duration, the frequency of patenting will decrease as reliance on trade secrecy protection increases.

Even without the complication of prior user rights, enhancing the desirability of keeping trade secrets relative to applying for patents may violate federal policy. As the Kewanee Court stated:

If a State, through a system of protection, were to cause a substantial risk that holders of patentable inventions would not seek

268. See U.S. Consr. art. I, $\S 8$. Congress is considering other measures that could affect significantly the flow of information: H.R. 2281, 105th Cong., (1998) would create civil and criminal prohibitions against use, manufacture, or sale of devices that are primarily designed or produced for the purpose of circumvention of copyright proteetion systems; S. 1146, 105th Cong., (1998), would outlaw circumvention. See also Dreyfuss, supra note 6.

Arguably, the Economic Espionage Act was enaeted under Congress' Commerce Clause power and is, thus, not bound by the Limited Times provision in the Constitution's Copyright Clause. However, a substantial question remains as to how far Congress can use one constitutional power to undermine limitations in other provisions. See Railway Executives Ass'n v. Gibbons, 455 U.S. 457, 468-70 (1982) (holding that nonuriform bankruptcy laws cannot be enacted pursuant to the commerce power as a way to avoid limitations in the Bankruptcy Clause).

269. See 143 Cong. REC. S 12637, 12639 (daily ed. Nov. 13, 1997) (statement of Sen. Bond on the Omnibus Patent Act of 1997); Request for Comments on Patent Law Harmonization, 58 Fed. Reg. $44,323,44,324$ (1993).

270. If the $\S 102(\mathrm{~g})$ cases discussed supra in the text accompanying note 263 are right, another response is that the main argument is not actually correct. However, those cases are controversial, and so there is a real risk of losing, to a later-filed patent, the right to exploit a technology. 
patents, but rather would rely on the state protection, we would be compelled to hold that such a system could not constitutionally continue to exist. ${ }^{271}$

\section{The "Rights Distinction"}

The drafters of Article $2 \mathrm{~B}$ may well be willing to concede that there are problems with using the secrecy approach to rationalize what they have done. To a great extent, they rely on the second line of reasoning, which distinguishes between rights that run against individuals and rights that run against the world. Thus, the Prefatory Note to the 1998 Annual Meeting Draft of Article 2B addresses the normative question whether, consistent with the Constitution, states are empowered to create transactional rights that have the effects discussed above:

As stated in the Copyright Act, federal property law precludes state law that creates rights equivalent to property rights created under copyright. But as both a practical and a conceptual matter, copyright (or patent) do [sic] not generally preeinpt contract law. Indeed, contracts are essential to use the property. A contract defines rights between parties to the agreement, while a property right creates rights against all the world. They are not equivalent. ${ }^{272}$

Armed with this distinction, the drafters argue for a theory of party autonoiny. ${ }^{273}$ Obligations that are in tension with federal principles can be imposed so long as they are the product of equal bargaining power. As noted earlier in connection with liquidated damages, the drafters view negotiated clauses as "per se reasonable." 274

There are two main 'sticking points in the drafters' position. First, there is little to indicate that the Supreme Court would be willing to adopt their distinction. That is not to denigrate the distinction's relevance to the problein; it may well afford a basis for permitting greater flexibility in licensing. It does, however, make it less likely that Article $2 \mathrm{~B}$ will survive a preemption challenge in its current form. Second, the distinction may not be capable of doing all the work required of it.

As the citation above indicates, the drafters are relying on ProCD, Inc. v. Zeidenberg, a decision by Judge Frank Easterbrook for the

271. Kewanee Oil Co. v. Bicron Corp., 416 U.S. 470,489 (1974).

272. U.C.C. art. 2B Prefatory Note at 15 (Annual Meeting Draft, July 24-31, 1998) (emphasis in original) (citing ProCD, Inc. v. Zeidenberg, 86 F.3d 1447 (7th Cir. 1996), for the proposition that copyright and patent do not preempt contracts) (other citations omitted); see also id. $\S 2 \mathrm{~B}-105$ reporter's note 2.

273. See, e.g., id. art. 2B Prefatory Note at 13-14, § 2B-106 reporter's notes 1, 2 (adopting the theory of party autonoiny).

274. Id. § $2 \mathrm{~B}-704$ reporter's note 1 . 
Seventh Circuit. ${ }^{275}$ That case enforced a "clickwrap" license on a CDROM telephone directory, under the terms of which the user of a data base agreed to use it only for consumer (as opposed to commercial) uses. The telephone directory was precisely the type of subject matter that Feist declared uncopyrightable as a matter of statutory and constitutional law. Nevertheless, Judge Easterbrook enforced the restriction. He analyzed the issue under section 301 of the Copyright Act. Focusing on the part of the provision that permits states to create rights that are not "equivalent to any of the exclusive rights within the general scope of copyright," 276 he held that the use restriction passed muster. It ran only against individuals, not against the world. ${ }^{277}$

Judge Easterbrook has enriched the field of intellectual property law in his scholarship ${ }^{278}$ and in his published opinions. ${ }^{279}$ However, the Supreme Court has yet to adopt his Chicago-School brand of transactional freedom. In fact, the Supreme Court has taken the opposite position, holding that federal intellectual property policy preempts state contract law. Thus, in Lear, Inc. v. Adkins, ${ }^{280}$ the Court refused to enforce a contract term that required a licensee to continue to pay royalties after the patent has lapsed. According to the Court,

Licensees may often be the only mdividuals with enough economic incentive to challenge the patentability of an inventor's discovery. If they are muzzled, the public may continually be

275. ProCD is cited in several other places in the 1998 Annual Meeting Draft as well. See, e.g., id. $\S \S 2 \mathrm{~B}-208$ reporter's note 4,2B-617 reporter's note 2(c). The draft also relies heavily on another Easterbrook opinion, Hill v. Gateway 2000, Inc., 105 F.3d 1147 (7th Cir. 1997). See, e.g., U.C.C. \$§ 2B-112 reporter's note 2, 2B-207 reporter's note 5 (Annual Meeting Draft, July 24-31, 1998). Hill enforced a "shrinkwrap" license deeming one who uses a purchased product to have agreed to terms in a license found when the packaging is opened. See 105 F.3d at 1148 . The contract provision in Hill was to arbitrate disputes. See id. It thus differs from the one in ProCD in that it leads to enforcement of an obligation that federal law clearly promotes. See, e.g., Mastrobuono v. Shearson Lehman Hutton, Inc., 514 U.S. 52, 56 (1995). Federal law does not promote the privatization of uncopyrightable material at issue in ProCD. Thus, it is hard to see what support the drafters can draw from Hill's arguably narrow holding.

276. 17 U.S.C. $\$ 301(a)$, (b)(3).

277. See ProCD, 86 F.3d at 1454-55.

278. See, e.g., Frank H. Easterbrook, Cyberspace and the Law of the Horse, 1996 U. CHI. LEGAL F. 207 (discussing intellectual property law for cyberspace); Frank H. Easterbrook, The Court and the Economic System, 98 HARV. L. REv. 4 (1984) (arguing that courts should consider the dynamics of the transactions with which they are dealing).

279. See, e.g., American Dental Ass'n v. Delta Plans Ass'n, 126 F.3d 977 (7th Cir. 1997) (finding taxonomy to be copyrightable); Lee v. A.R.T. Co., 125 F.3d 580 (7th Cir. 1997) (holding that mounting of work on ceramic tile is not a derivative work under the Copyright Act); Sununark, Inc. v. Ocean Spray Cranberries, Inc., 64 F.3d 1055 (7th Cir. 1985) (holding plat map copyrightable and infringed, and applying standards for awarding costs); Grain Processing Corp. v. American MaizeProducts Co., 893 F. Supp. 1386 (N.D. Ind. 1995) (determining damages in a patent infringeinent action while sitting as a trial judge by designation); In re Marhurkar Double Lumen Hemodialysis Catheter Patent Litigation, 831 F. Supp. 1354 (N.D. Ill. 1993) (upholding patent against challenges based on lack of disclosure, on sale bar, and obviousness, while sitting as a trial judge by designation).

280. 395 U.S. 653 (1969). 
required to pay tribute to would-be monopolists without need or justification. We think it plain that the technical requirements of contract doctrine must give way before the demands of the public interest . . . . ${ }^{281}$

Although Lear is not a recent case, and there has been discussion of reversing it, the efforts have gone nowhere. ${ }^{282}$

The Court has also been reluctant to uphold contracts on the theory that arms-length bargaining between adverse parties necessarily protects the public. Thus, in Brulotte $v$. Thys ${ }^{283}$ the Court refused to enforce a negotiated contract provision that required a licensee to pay royalties after patent expiration. The Court, in essence, rejected the notion that such a negotiation could be fair. In its view, the monopoly over the technology during the patent term gave the patentee leverage to extract an unwarranted reward for using the technology after it became freely available. ${ }^{284}$ Brulotte's leverage theory has not fared well in subsequent cases or in the economic literature, where the argument is made that patentees do not have leverage; licensees will not pay more for a technology than it is worth. ${ }^{285}$ However, the insight that a licensee will protect its own interests does not mean that a licensee will necessarily protect the public mterest. In some cases it will. Often, the licensee's interest is aligned with the public's because each wants the technology at the lowest price. In such cases, the bargain between the licensor and licensee serves as a proxy for a negotiation between the licensor and the public. But it can also be the case that a licensee and a licensor have joint interests adverse to the public interest. For exainple, the licensing parties might want to commit jomtly to exclude competitors and split the resulting supracompetitive profit. ${ }^{286}$ While debunking the leverage myth

281. Id. at $670-71$.

282. When the Advisory Commission on Patent Law Reform convened in 1990, it called for comments on the continuing utility of Lear. See Request for Comments for the Advisory Commission on Patent Law Reform, 56 Fed. Reg. 22,702, 22,703 (1991). When the Commission published its final report two years later, however, it did not recommend the statutory overruling of Lear, although it did call for legislation allowing a patentee to revoke a license when the licensee challenges the patent's validity in court. See AdVisory Commission on PATENT LAW Reform, A RePORT to the SECRETARY of CoMmerce 126 (1992). Thus far, Congress has not picked up on the proposal. (I note parenthetically that I have advocated the overruling of Lear for some time. See Dreyfuss, supra note 75.)

283. 379 U.S. 29 (1964).

284. See id. at 33.

285. See, e.g., Richard A. Posner, Antitrust Law: AN Economic Perspective 172-73 (1976); see also Robert H. Bork, The ANTrrrust PARAdox 372-75 (1978); Ward S. Bownan, Jr., Tying Arrangements and the Leverage Problem, 67 YALE L.J. 19, 23-24 (1957).

286. This argument concerning the externalities that licenses can produce on third parties is developed in Lemley, supra note 13, at 1284-86. 
has made it clear that license terms should rarely be considered per se unlawful, it does not extend to proving that they are per se lawful. ${ }^{287}$

This is not to say that reliance on the rights distinction is entirely misguided. The Supreme Court did uphold an intellectual property license with anticompetitive features in Aronson v. Quick Point Pencil $\mathrm{Co}^{288}$ Aronson had revealed a new key ring design to Quick Point in exchange for royalties, the level of which depended on whether a patent on the ring issued. Some time after the patent application was rejected, Quick Point withheld payments, claiming that the contract violated Lear and Brulotte. The Supreme Court rejected the argument, relying largely on the secrecy rationale. ${ }^{289}$ The decision can be understood, however, in terms of the rights distinction, as recognizing that federal innovation policy does not require that everyone have unfettered access to subpatentable technologies. ${ }^{290}$ So long as the key ring could be used by someone without paying royalties to Aronson, the public had no interest in releasing Quick Point from its obligation. With only contract law principles at stake, the Court upheld the agreement. ${ }^{291}$

The Aronson application of the rights distinction does not, however, fully map the situations at issue in Article 2B. In particular, a significant feature in Aronson was that the key ring was effectively in the public domain. The design could be reverse engineered from the product that Quick Point distributed. Accordingly, copies and follow-ons could be made freely and the price Quick Point could charge was limited by (potential) competition. ${ }^{292}$ In many Article $2 \mathrm{~B}$ cases-and arguably in ProCD as well-the information at issue can only be accessed by agreeing to the license; it is never, as a practical matter, available freely to anyone $\mathrm{m}$ the public. In effect, the clickwrap technology, coupled with the recognition of these licenses that was provided by ProCD and that would be codified by Article $2 \mathrm{~B}$, turns every right against an

287. See, e.g., Dep't of Justice and Federal Trade Comm'n, Antitrust Guidelines for THE LiCENSING OF INTELlectual Property $\$ 3.4$ (1995). The guidelines apply a rule of reason on the question whether a particular restriction violates antitrust laws. See id. As to misuse, some courts still take a per se approach. See, e.g., Meehan v. PPG Indus., 802 F.2d 881, 886 (7th Cir. 1986); see generally William Baxter, Legal Restrictions on Exploitation of the Patent Monopoly: An Econonic Analysis, 76 Y ALE L.J. 267, 327-29 (1966).

It is also worth noting that this rationale is somewhat inapposite to mass market agreements. Although Article 2B permits returu upon learning of restrictions, the right to return is not quite the same as the capacity to bargain.

288. 440 U.S. 257 (1979).

289. See id. at 262-63.

290. See Dreyfuss, supra note 75 , at 697.

291. For a discussion of these competing readings, see Lemley, supra note 13, at 1283-87.

292. See Dreyfuss, supra note 75 , at 696-97. 
individual into a right against the world. In such an environment, the rights approach has little meaning. ${ }^{293}$

\section{B. Article $2 B$ and State Law and Policy}

In addition to the limitations just discussed, which flow from federal innovation policy and federal intellectual property law, states also constrain what innovators can do with the information they develop. That is, while the states have long been active in protecting the fruits of innovation, they also have policies and laws that limit exploitation in the name of other interests. We have already seen the restrictions that are built into trade secrecy regimes. Like federal intellectual property rights, they create a mechanism for capturing economic return from creative investments, while at the same time protecting the public domain and ensuring leakage. Thus, under standard trade secrecy laws, only information that is valuable by reason of being secret is protectable; ${ }^{294}$ owners who do not take reasonable measures to inaintain secrecy can lose the right to control use, ${ }^{295}$ reverse engineering and independent discovery are not considered actionable; ${ }^{296}$ and there are temporal limits on injunctive relief. ${ }^{297}$ In some instances, there are other positive laws that also operate to annul trade secrets. For example, some states (and also the federal government) have enacted right-to-know legislation that requires innovators to make public information that could otherwise be protected and licensed. ${ }^{298}$

293. See Jane C. Ginsburg, Copyright, Common Law, and Sui Generis Protection of Databases in the United States and Abroad, 66 U. CIN. L. Rev. 151, 167 (1997); Brandon L. Grusd, Contracting Beyond Copyright: ProCD, Inc. v. Zeidenberg, 10 HaRv. J.L. \& TECH. 353, 365 (1997).

294. Thus, the UTSA defines a "trade secret" as information that "derives independent economic value...f from not being generally known." UNIF. TRADE SECRETS ACT § 1(4)(i) (amended 1985), 14 U.L.A. 438 (1990); see also Restatement (ThIRD) of UNFAIR Competition $\S$ 41 (1995); Lederman, supra note 30, at 938, 942-66 (noting the limits states place on the crime of trade secrecy theft). For a discussion of cases dispensing with the reqnirement of secrecy, see Robert P. Merges et al., Intellectual. Property in the New Technological Age 43-45 (1997).

295. UNIF. TRADE SeCRETS ACT § 1(4)(ii) (amended 1985), 14 U.L.A. 438 (1990), requires that the information for which protection is sought have been "the subject of efforts that are reasonable under the circumstances to maintain its secrecy."

296. See UNIF. TRADE SECRETS ACT § 1(1) (amended 1985), 14 U.L.A. 438 (1990); see also RESTATEMENT (THIRD) OF UNFAIR COMPETITION $\S 43$ ("Independent discovery and analysis of publicly available products or information are not improper means of acquisition."); $c f$. Chicago Lock Co. v. Fanberg, 676 F.2d 400 (9th Cir. 1982) (refusmg to enjoin the publication of key codes for tubular locks that were acquired by independent analysis).

297. See UNIF. TRAdE SEcrets ACT \$ 2(a) (amended 1985), 14 U.L.A. 449 (1990); cf. LambWeston, Inc. v. McCain Foods, Ltd., 941 F.2d 970, 974-75 (9th Cir. 1991) (refusing to enjoin use of a trade secret perpetually). See generally Peter C. Quittmeyer, Trade Secrets and Confidential Information Under Georgia Law, 19 GA. L. ReV. 623 (1985).

298. See Mary L. Lyndon, Information Economics and Chemical Toxicity: Designing Laws to Produce and Use Data, 87 Mich. L. Rev. 1795, $1855-59$ (1989); see also Mary L. Lyndon, Secrecy and Innovation in Tort Law and Regulation, 23 N.M. L. REV. 1, 22-34 (1993). 
States also protect innovation through the enforcement of covenants not to compete. These covenants allow creators to limit the ability of those to whom valuable information is confided to enter a business where the information is, or might be, used competitively. ${ }^{299}$ As with trade secrecy, however, this branch of the law does not give innovators unlimited rights. Covenants not to compete are usually strictly construed, especially when they apply to creative imdustries. ${ }^{300}$ Only specific information is protected, leaving the parties free to utilize any expertise, skills, and general experience they acquired in the course of the relationship that gave rise to the covenant. ${ }^{301}$ Covenants that lack temporal limits or reasonable geographic boundaries are either not enforced or are subjected to judicial "blue penciling." ${ }^{302}$ In some places, these agreements are not enforceable in the employment context. ${ }^{303}$ Again, there are exogenous limitations. For instance, covenants not to compete are soinetimes subjected to antitrust scrutiny as unreasonable restraints on the market for labor. ${ }^{304}$

\section{Article 2B's Intersection with State Law Generally}

Given this complex backdrop of state action regarding innovation, early drafts of Article 2B were surprising in that they barely discussed state law or policy. For example, in the November 1, 1997 Draft, the

299. See, e.g., The Gillette Co. v. Williams, 360 F. Supp. 1171 (D. Conn. 1973) (enforcing covenant not to enter into the safety blade market). Trade secrecy law and covenants not to compete merge in the inevitable disclosure doctrine. See, e.g., PepsiCo, Inc. v. Redmond, 54 F.3d 1262 (7th Cir. 1995) (permitting the enforceinent of a covenant not to coinpete when there is a danger that the new employer will inevitably benefit from the previous employer's trade secrets).

300. See, e.g., Maureen B. Callahan, Comment, Post-Employment Restraint Agreements: A Reassessment, 52 U. CHI. L. REv. 703, 712 (1985).

301. See, e.g., Inflight Newspapers, Inc. v. Magazines In-Flight, LLC, 990 F. Supp. 119, 126 (E.D.N.Y. 1997) (holding that former enployee "should be allowed to use the skills and knowledge he acquired in his overall experience" while working for plaintiff former enployer); Ivy Mar Co., Inc. v. C.R. Seasons Ltd., 907 F. Supp. 547, 557 (E.D.N.Y. 1995) (rejecting trade secret protection for customer lists that are recalled, unless the information was memorized intentionally); Abraham Zion Corp. v. Lebow, 593 F. Supp. 551 (S.D.N.Y. 1984) (mere recollection of customer information is not actionable); Darby Drug Co., Inc. v. Zlotnick, 573 F. Supp. 661, 663 (E.D.N.Y. 1983) ("[H]ad Zlotnick simply memorized the names of customers, it eould hardly be said that he thercby aetcd tortiously."). See also Miles J. Feldinan, Toward a Clearer Understanding of Protectable Information: Trade Secrets and the Employment Relationship, 9 HIGH TECH. L.J. 151 (1994).

302. See Alfred G. Feliu, Primer on Individual EMPloyee Rights 61 (1992); G. Richard Shell, Contracts in the Modern Supreme Court, 81 CALIF. L REv. 431, 529 n.52 (1993); see generally Emily J. Kuo, Comment, The Enforceability Gap of Covenants Not to Compete in Telecommuting Employment Relationships, 1996 U. CHI. LEGAL F. 565 (1996).

303. See, e.g., CAL. Bus. \& Prof. CODE $\$ 16600$ (Deering 1992); Loral Corp. v. Moyes, 174 Cal. App. 3d 268, 276 (1985). See generally David A. Cathcart \& Christopher J. Martin, Contracts witl Employees: Covenants Not to Compete and Trade Secrets, in ALI-ABA Resource Materials, LABOR \& EMPLOYMENT LAW 679, 704-07 (6th ed. 1992), available in Westlaw, ALI-ABA database, R176 ALI-ABA 679.

304. See, e.g., Note, The Antitrust Implications of Employee Non-Compete Agreements: A Labor Market Analysis, 66 MrNN. L. REv. 519, 525-34 (1982). 
only provision dealing with the topic was section $2 \mathrm{~B}-104$, which gave precedent to any provision of state law that established rights of access. ${ }^{305}$ However, the limitation was not well developed in either the text or the accoinpanying reporter's notes; nothing in that draft dealt with state innovation policies embodied in other state laws. This allowed Article 2B to be read either as neutral on state principles (that is, as allowing courts to adapt Article 2B in light of other state policies), or as superseding other state laws, either in the name of national uniformity or on the ground that the adoption of Article $2 \mathrm{~B}$ represented a change in the views of the adopting states.

Starting with the March 1998 Draft, state issues received more attention, but the method for applying Article $2 \mathrm{~B}$ in light of other state doctrine remained poorly articulated. Thus, this version of section $2 \mathrm{~B}-$ 104 recognized that there might be conflicts between Article $2 \mathrm{~B}$ and "statute[s] or regulation[s] . . a as judicially construed,"305 and also with certain formal contracting requirements (such as the requirenient of a signed writing). ${ }^{307}$ It provided that conflicting statutory law "in effect on the effective date of this article" that established rights of access to, or use of, information or informational property rights controlled over Article $2 \mathrm{~B}$, as did statutory law protecting consumers. ${ }^{308}$ As to contract formalities, Article 2B would control over other state laws "in effect on the effective date of this article. ${ }^{2309}$ These provisions created a series of questions: Why did the section deal only with statutes, regulations and their construction-what of state common law, such as trade secrecy law in states that have not enacted a statute such as the UTSA? Why did the draft focus only on conflicts between Article 2B and the statutory law existing on its effective date? What of subsequent legislation touching on the licensing of information and informational rights? One could, for example, easily envision the passage of new state antitrust laws to deal with monopolization of computer operating systeins and browsers. ${ }^{310}$ If common law doctrines are not abohshed sub silentio, and

305. See U.C.C. § 2B-104 (Draft, Nov. 1, 1998).

306. U.C.C. \& 2B-104(a) (Draft, Mar. 1998).

307. See id. § 2B-104(b)-(c).

308. Id. § 2B-104(a).

309. Id. § 2B-104(b).

310. U.C.C. $\$ 2 B-104(b)$ (Draft, Mar. 1998) made this explicit for laws containing contract requirements; section 2B-104 reporter's note 1 stated the same rule for conflicts governed by subsection 2B-104(a). The drafters apparently anticipated that all such subsequent enactments would address the question of conflict with Article 2B, predicting that "[s]ubsequent regulations and statutes on any topic will contain their own provisions as to their impact on pre-existing law ...." Id. § $2 \mathrm{~B}$ 104 reporter's note 1 . However, it does not take much knowledge of legal history to suspect that this will not occur with any degree of frequency. Governments do not regularly canvas existing laws when they enact new ones. See, e.g., William N. EskRidge, JR. \& PhiliP P. Frickey, CASES AND Materials on Legislation: Statutes and the Creations of Public Policy 801-02 (1988). Of course, the usual rule is that a later-enacted statute controls over an earher one, see, e.g., 
if later-enacted statutes are not ineffective $a b$ initio, how should courts reconcile conflicts?

In some ways, the 1998 Annual Meeting Draft is a real improvement. All issues regarding the relationship between state law and Article 2B law have been moved to section 2B-105, where they join the discussion of the impact of federal law on Article $2 \mathrm{~B}$. That section explicitly recognizes that trade secret laws and unfair competition laws "supplement" Article 2B. ${ }^{311}$ As before, contract formalities are determined by Article 2B, not prior law; ${ }^{312}$ consumer protection laws effective as of the date of Article 2B control over contrary provisions of Article $2 \mathrm{~B}{ }^{313}$ Equally important, other provisions of Article $2 \mathrm{~B}$ now alert courts to the possibility of conflict, and explicitly provide that other law will sometimes control. For example, activities that are "permitted under applicable law in the absence of" a contractual limitation are not to be regarded as breaches. ${ }^{314}$ Obligations can survive termination of an agreement only "to the extent enforceable under applicable law."

The Annual Meeting Draft, however, does not go nearly far enough. Unlike the term "preempt," which section 2B-105 applies to federal law, the word "supplement" provides very little content. This leaves unanswered the question of whether adopting Article 2B would signify repeal of some of the public-regarding aspects of state informational rights law. For example, a reporter's note in the March 1998 Draft made specific mention of the survival of inandatory disclosure laws, ${ }^{316}$ but this reference was omitted from the 1998 Annual Meeting Draft. The omission could be taken as indicating that these laws no longer take precedence over Article 2B. On the other hand, the 1998 Annual Meeting Draft also omits mention of the enforceability of contractual agreements barring disclosure. Thus, it is possible that the drafters no longer view a discussion of mandatory disclosure laws as necessary.

The new allusion to other applicable laws is similarly vague. Does "law" mean case law and statutory law? Law that existed prior to adoption of Article $2 \mathrm{~B}$ ? Law adopted later that fails to mention Article

Norman J. Singer, 2B Sutherland's Statutes \& Statutory Construction \$ 51.01 (5th ed. 1992), but the explicit language of section 2B-104 on conflicts between Article $2 \mathrm{~B}$ and statutes cnacted prior to its passage could have been read to disable states from trumping Article $2 \mathrm{~B}$ with new legislative measures, unless the intent to do so is made explicit. Cf. U.C.C. \& 2B-104 reporter's note 2 (not distinguishing between mandated disclosure laws enacted before or after passage of Article $2 \mathrm{~B}$ ).

311. ' U.C.C. \& 2B-105(b) (Annual Meeting Draft, July 24-31, 1998).

312. See id. \$ 2B-105(d).

313. See id. \& $2 \mathrm{~B}-105(\mathrm{c})$.

314. Id. § $2 \mathrm{~B}-307(\mathrm{~b})$.

315. Id. § 2B-625(b)(10).

316. See U.C.C. § 2B-104 reporter's note 2 (Draft, Mar. 1998). 
$2 \mathrm{~B} ?^{317}$ Given the distinctions made in earlier drafts, greater clarity would be useful. Furthermore, even if one knew what law was being discussed, there would still be a need for guidance on how to determine when such laws should be considered "applicable" and when they should be deemed superseded by the enactment of Article 2B. ${ }^{318}$ Presumably, courts will decide these issues on a case-by-case basis, but one can only speculate as to how they should conduct their analyses. For example, one could argue that since Article $2 \mathrm{~B}$ is intended to create uniform licensing rules throughout the states, every state has an obligation to eliminate all restraints on licensing other than those specifically designated by Article $2 \mathrm{~B}$ as enduring. That resolution would be so radical, however, that it is difficult to believe it would not have been signaled in a prominent fashion.

\section{Article $2 B$ 's Intersection with State Laws and Policies Specifically}

Less drastically, Article 2B could be read as potentially conflicting only with those state policies aimed at adjusting the balance between the users and producers of information products, leaving state law based on other goals intact. For example, legislation based on extrinsic policy considerations, such as much of the right-to-know legislation and legislation against non-compete agreements, would reinain unaffected. Right-to-know provisions, premised on concerns for health and safety, require innovators to reveal what they have invented in order for the state to momitor, regulate, and protect employees, customers, and neighbors froin the harms that new products can inflict. ${ }^{319}$ Analogously, some of the restraints on covenants not to compete stem from concerns for the welfare of employees. They enable eniployees to capture returns from their own inventive efforts, ${ }^{320}$ to earn a living in their chosen field, to bargain for higher pay, and to put their skills to their highest and best use. ${ }^{321}$ It has always been evident that these disclosure requirements and limits on nonconipete agreements sacrifice imterests in innovation and in

317. U.C.C. § 2B-105 reporter's note 5 (Annual Meeting Draft, July 24-31, 1998) contains the same assumption that subsequent law will refer to Article $2 \mathrm{~B}$ specifically.

318. See id. $\S 2 \mathrm{~B}-105$ reporter's note 5 ("Of course, when the common law does conflict with Article 2B, the later-enacted, uniform statutory treatinent of the UCC (Article 2B) controls.").

319. See Lyndon, supra note 298 , at $1855-59$.

320. See, e.g., Wexler v. Greenberg, 160 A.2d 430, 433 (Pa. 1960) ("We are thus faced with the problen of determining the extent to which a former employer ... can restrict his ex-enuployee, a highly skilled chemist, in the uses to which this employee can put his knowledge of formulas and methods he himself developed...."). See generally Steven Cherensky, A Penny for Their Thoughts: Employee-Inventors, Pre-invention Assignment Agreements, Property, and Personhood, 81 CalIF. L. REv. 595 (1993).

321. See, e.g., Purchasing Assocs., Inc. v. Weitz, 196 N.E.2d 245, 247 (N.Y. 1963) (noting that there are "powerful considerations of public policy which militate against sanctioning the loss of a man's livelihood"). 
contractual freedom in order to further other important policies. The failure of Article $2 B$ to mention this sacrifice can be taken not as implymg that the policies are to be abolished, but rather as evidence that they are perceived by the states as wholly unrelated to rules about licensing.

The same cannot be said, however, for state statutes, common law, and doctrines that were adopted to further a state's ideas on how to promote creativity. Many of the current limits on trade secrecy and confidentiality agreements exist to foster competition among innovators; ${ }^{322}$ with greater contractual freedom, licensing parties will sometimes make agreements that decrease competition. Similarly, limits on covenants not to compete preserve employee mobility, which in turn, promotes creativity. Thus, the freedom to change jobs promotes the diffusion of information and increases spillover possibilities. ${ }^{323}$ Mobility also allows workers to leave their jobs and become entrepreneurs in the innovation markets. ${ }^{324}$ Admittedly, there are instances in which state limits on trade secrets and covenants not to compete were created to avoid federal preemption problems. ${ }^{325}$ Since Article 2B has its own provision on preemption, separate policies will no longer be necessary. ${ }^{326}$ In other situations, however, Article $2 \mathrm{~B}$ could be read as representing a change in the views of adopting states on how innovation is best promoted. If so, then these laws are no longer "applicable." For a document that is intended to promote uniformity and predictability, failure to address these issues is a substantial omission. A reporter's note stating that "state law concerning trade secrecy is preserved and may affect the terms of contracts otherwise within Article $2 \mathrm{~B}^{\prime 327}$ is simply not enough.

322. See, e.g., American Broadcasting Cos. v. Wolf, 420 N.E.2d 363, 368 (N.Y. 1981) (underlying the strict treatment of post-employment restraints is "the general public policy favoring robust and uninhibited competition[, which] should not give way merely because a particular employer wishes to insulate himself from competition ..."); $c f$. Lamb-Weston, Inc. v. McCain Foods, Ltd., 941 F.2d 970 (9th Cir. 1991) (refusing to enjoin use of a trade secret perpetually in order to create an opportunity for competition).

323. See Wexler, 160 A.2d at 433 ("We must therefore be particularly mindful of any effect our decision in this case might have in disrupting this pattern of employee mobility ... in view of ... the harm to the public in general in forestalling, to any extent, widespread technological advances.").

324. See, e.g., Callahan, supra note 300, at 706; see also Crista Hardy, Sun Micro Sued by Reseller over Aborted DRAM Deal, ElECTRONIC NEws, Apr. 29, 1996, at 1 (quoting a Silicon Valley executive's observation that "[o]n the good side, [mobility] really allows people to be creative in starting new companies. It creates a lot of this wealth and entrepreneurial zeal, in terms of bringing new and better solutions to the market, because there's a lot of ownership in doing that."); Dan Goodin, New Trade Secret Laws Will Cast a Wider Net, RECORDER, Dec. 23, 1996, at 1 (quoting a lawyer's observation that more stringent trade secrecy laws in California could "have a chilling effect on employee mobility, which Silicon Valley has depended on for much of its vitality").

325. See, e.g., Chicago Lock Co. v. Fanberg, 676 F.2d 400, 405 (9th Cir. 1982).

326. See U.C.C. § 2B-105(a) (Annual Meeting Draft, July 24-31, 1998). As I have stated beforc, the provision on federal precinption could also use more commentary.

327. Id. \& 2B-105 reporter's notc 5 (einphasis added). 
There are also important questions left unanswered regarding Article 2B's references to consumer protection laws. ${ }^{328}$ One concerns the impact of express language concerning prior-enacted law on legislation that is adopted after Article $2 \mathrm{~B}$, but which fails to mention Article $2 \mathrm{~B} .{ }^{329}$ More important is determining just what "consuner protection" means. Those who attended the Conference at the University of California at Berkeley on which this symposium issue is based know that the proponents of Article 2B parry concerns over the effect of Article $2 \mathrm{~B}$ on both the public domain and innovation by noting how consumerprotective Article $2 B$ is. One can take this to mean that access rights are considered a part of consumer protection. ${ }^{330}$ At the same time, however, the tern "consunier protection" more usually is used in connection with laws that ensure that consumers are treated fairly in the marketplace and are not injured by the products that they buy. Indeed, Ray Nimmer, the reporter of Article 2B, has described the consumer provisions of Article $2 \mathrm{~B}$ im exactly this way ${ }^{331}$ Moreover, since very few consumers are innovators - that is, simce very few intend to use their purchase to reverse engineer and make new products-citing consumer protections makes little sense in this context. But given the confusion that the drafters have themselves engendered, a specific defimition of consumer protection would be helpful. ${ }^{332}$

\section{A Reasoned Perspective}

Admittedly, the above analyses are irrelevant to those parts of Article 2B that are designed only to facilitate licensing that is already taking place. However, for those features of the draft that would allow licensors to extract more profits from their work than they can under current law, the picture that enierges from the analysis is rather bleakmany of the restrictive practices will not survive a federal preeniption challenge or withstand scrutiny under current state law. For federally

328. See id. § 2B-105(c).

329. See text following note 307 .

330. Cf. U.C.C. \$ 2B-208 reporter's note 6 (Annual Meeting Draft, July 24-31, 1998) (discussing intellectual property issues in the context of a key consumer-protection provision).

331. See Nimmer, UCC Revisions, supra note 12, at 371. Nimmer writes:

In contrast, Article 2B expands "consumer" protections in nany ways, including: invalidation of some terms in a form contract even if they are fully conscionable terms, invalidation of contract choice of forum that unfairly disadvantages a consumer, creation of a non-waivable duty of reasonable care to avoid viruses im a product, presumptions about transferability, length of license, requirement that disclaimers be in a writing, implied right to any uses of software necessary to the expressly granted use, consumer not bound by a standard form unless it made an affirmative act of assent to the Id.

form, and advertising recognized as a potential source of an express warranty.

332. Alternatively, the proponents of Article $2 \mathrm{~B}$ could abandon the pretense of protecting innovation through "consumer protection" and face up to the question whether Article $2 B$ is so protective of proprietary rights that it will inhibit creativity and follow-on inventions. 
protected works, that prognosis is perhaps where things should lie. Copyright and patent law represent federal thinking on how the balance between private and public interests should be adjusted; arguably, states should not be altering that balance. But for works that do not enjoy federal protection, it is not so clear that the current balance is, in fact, the right one. Perhaps these works are too leaky and the drafters are right: some holes should be plugged because promoting innovation with the promise of a reward is more important than the free flow of ideas. And while it is true that both the Supreme Court trilogy (in Kewanee, Bonito Boats and Feist) and current state case law seem to leave very little room for giving more to licensors, these outcomes merit reexamination in light of the new kinds of products and distribution mechanisms that are available today.

There are, for example, important differences between the Sega hypothetical and ProCD. In Sega, even if the posited restrictions are considered unenforceable as a matter of federal law, Sega is not left bereft of all reward. Because reverse engineering took considerable time and effort, Sega had sigmificant lead time in which to recoup its costs. Moreover, it competes on an almost level playing field with its new competitor, which, after all, had to pay the costs associated with figuring out the interfaces and developing games to sell. In contrast, those who copy and distribute computerized data bases, such as the CD-ROM directory in ProCD, enjoy almost pure free rides. Unless we are to understand the constitutional scheme and federal policy as requiring a gap in intellectual property coverage through which important and commercially significant intellectual efforts are required to fall, there must be some protected space for subpatentable and subcopyrightable works, when that is necessary to assure an adequate return on development efforts. ${ }^{333}$

Others have written about statutory responses to this free rider problem, ${ }^{334}$ but in the absence of movement on the legislative front, the drafters of Article 2B cannot be faulted for facilitating contract-based solutions. Despite the problems noted above, courts should not be dismissing their solutions out of hand. As for federal policy, it is important to note that even though neither the secrecy approach nor the rights distinction provides a full defense to preemption, there are situations where they dovetail neatly. That is, where information is genuinely

333. Indeed, in International News Service v. Associated Press, 248 U.S. 215 (1918), the Supreme Court essentially imvented the doctrine of misappropriation to fill such a void. See generally Roehelle Cooper Dreyfuss, A Wiseguy's Approach to Information Products: Muscling Copyright and Patent into a Unitary Theory of Intellectual Property, 1992 SuP. CT. REv. 195, 231-33.

334. See, e.g., J.H. Reichman \& Pamela Samuelson, Intellectual Property Rights in Data?, 50 VAND. L. REv. 51 (1997); Pamela Samuelson et al., A Manifesto Concerning the Legal Protection of Computer Programs, 94 ColUM. L. REv. 2308 (1994). 
secret and cannot be reverse engineered, the secrecy approach inay be plausible even though the rights distinction could not work because of lack of any public access. Conversely, where the secrecy rationale is inoperative, the rights distinction could provide some room for asserting proprietary interest in public, non-federally protected material. Moreover, contract rights do not always destroy the public-regarding adjustments to exclusive rights systems. Indeed, the converse is sometimes true. As Judge Easterbrook poimted out, the use restriction in ProCD permitted price discrimination that reduced deadweight loss. ${ }^{335}$

The trick, then, is for the states that adopt Article 2B to find ways to assess the effect of particular restrictions. It will be no easy task: it is not helpful that the drafters chose to leave the applicability of state law ambiguous and to pass the buck to courts on questions of federal law. Of course, many of the cases will come up, as ProCD did, as preemption challenges under the Copyright Act or on conflicts preeinption grounds, ${ }^{336}$ issues on which much ink has already been spilled. ${ }^{337}$ Preemption based on patent law policy is more amorphous, although there is no shortage of commentary there as well. ${ }^{338}$ Ultimately, however, decisions will need to be made on a case-by-case basis, and the most pomted criticism that I can make of this draft is to reiterate what a real loss it is that the drafters, having spent so much time devising Article $2 \mathrm{~B}$, did not provide us with more of their thinking.

The drafters argue that they cannot do more because states have no role im determining federal law and because the ALI inembership "rejected the demand to take one or the other side" in the intellectual property rights policy debate. ${ }^{339}$ But giving guidance is not the same as taking sides; providing a framework for analysis is not a determination of the law. Moreover, the drafters are mistaken in thinking that the failure to comment is neutral. ${ }^{340}$ Absent guidance, innovation will be stifled at the margin because people will enter into agreeinents, or fail to challenge provisions, that violate federal policy. The drafters have come a considerable distance in this regard in that the draft now imdicates some

335. See ProCD, Inc. v. Zeidenberg, 86 F.3d 1447, 1449 (7th Cir. 1996).

336. See, e.g., Vault Corp. v. Quaid Software Ltd., 847 F.2d 255 (5th Cir. 1988).

337. See, e.g., Lemley, supra note 13, at 1269-74; Raymond T. Nimmer, Federal Preemption in Intellectual Property Law, supra note 12, at 100-01, 112-15; David A. Rice, Public Goods, Private Contract and Public Policy: Federal Preemption of Software License Prohibitions Against Reverse Engineering, 53 U. PITT. L. REv. 543, 602-16 (1992).

338. See, e.g., Rice, supra note 337, at 577-96; Dreyfuss, supra note 75, at 678-93.

339. U.C.C. art. 2B Prefatory Note at 16 (Annual Meeting Draft, July 24-31, 1998). See also UCC Article 2B Preemption Motion Fails: ALI Says Assent Provisions Need Work, 45 U.S.L.W. 2720, 2720 (May 26, 1998) (attributing to the drafters the view that "state law, including the Uniform Commercial Code, is not the proper forum to resolve" the issue of federal preemption, and that "it was a matter for Congress to decide").

340. See U.C.C. art. 2B Prefatory Note at 16, $\$ \S 2 B-105$ reporter's note 3, 2B-208 reporter's note 6 (Annual Meeting Draft, July 24-31, 1998). 
of the places where other law will be applicable, but providing an analytical framework would go much further towards assuaging concerns that state (and federal) courts will not get the balance right. Alternatively, perhaps the ALI should consider taking on this project. The Institute previously has not shied away from commenting on federal/state interactions $;^{341}$ providing a supplement to Article $2 \mathrm{~B}$ would be a worthy task. I will content myself with pointing out some things the drafters, or the ALI, could add to the latest draft-if not to the text, then to the reporter's notes, comments, or supplementary material.

\section{Suggested Improvements to Article $2 B$}

\section{Clarify the Relationship Between Article $2 B$ and State Law}

Whatever the merits of the drafters' arguments for reticence regarding the relationship between Article $2 \mathrm{~B}$ and federal law, there is no reason to refuse a more proactive role on state law. Article $2 \mathrm{~B}$ can and should make clear its positions on what laws are "applicable," on when Article 2B supersedes prior common law, and on the status of laterenacted statutes silent on Article $2 \mathrm{~B}$ issues. It should also provide a framework for dealing with potential conflicts.

It may be that the states are so divided on these issues that the only way for the drafters to be genuinely explicit on them will be by offering more than one choice of language for section 2B-105. That would not produce uniformity, but it would make the effect of licensing agreements in each state more predictable. Alternatively, the drafters could leave the text of section $2 \mathrm{~B}-105$ as it is, but augment it with a set of illustrations of concrete fact patterns that commonly give rise to conflicts questions, along with proposed analyses. Illustrations would permit a nuanced analysis of different kinds of conflicts (for example, between licensing freedom on the one hand, and innovation policy, safety and health, or employee welfare on the other). Illustrations would also provide interested parties with more tools with which to assess their own situation. Furthermore, better guidance would help alleviate the very difficult choice of law problems that surely will arise in multistate applications of Article $2 \mathrm{~B}$, when more than one state policy will be in play. ${ }^{342}$

It could, however, easily turn out that states are of one mind on interrelationship issues. It is not unlikely that all of the states will take the

341. For example, at the ALI's May 1998 meeting, the debate on Article 2B was preceded by a discussion of a proposed revision to 28 U.S.C. $\S 1367$ on the jurisdiction of federal courts to entertain state law claims. I attended both sessions and was somewhat startled by a statement at the Article $2 \mathrm{~B}$ session that discussing federal law was beyond the ambit of the ALI.

342. See U.C.C. $\$ 2 B-105$ reporter's note 5 (Annual Meeting Draft, July 24-31, 1998), which suggests that in multistate transactions, the law of the place whose substantive law applies should govern. That result could lead to suboptimal situations, for example, when a technology is developed in one state but used in a way that pollutes a second state. 
same view on the survival of policies that are aimed at health, safety, and employee welfare; it is certainly true that policies adopted to avoid federal preemption challenges can be discarded. A persuasive analysis of the balance that should be struck between the interests of licensors or licensees, and between the interest of developers, those who use their products, and those who build on their technology might be adopted by all of the states, thereby producing a common licensing law for the nation.

\section{Endorse Blue Penciling}

As noted above, limiting restrictions on the use of information is not a new problein for state courts; they have long entertained challenges to restraints on the use of protected information in the context of covenants not to compete. Their usual rule in these cases is to enforce restrictions only to the extent that they are reasonable. ${ }^{343}$ The drafters could recommend that a similar approach be taken toward contracts that come within the purview of Article 2B. That would require a redraft of those sections that inandate enforcement of all contract terms unless a court finds a clause unconscionable. ${ }^{344}$ There is very little coinmentary on unconscionability, and the omission can be interpreted to negate the court's power to consider reasonableness or to blue pencil. Adding a discussion would clarify the extent of judicial discretion. It would also encourage courts to consider such questions as whether a restriction was aimed at recouping the costs of invention or at preventing competition; whether a restriction's effect on innovation was reasonable in light of the legitimate needs of the licensor; and whether a restraint was so widespread that rights, effectively, were being exercised against the world. ${ }^{345}$ This kind of analysis would allow a court to reach the same conclusion that Judge Easterbrook did in ProCD without also permitting the kind of overreaching by licensors that obtains in the Sega hypothetical.

At first blush, it may appear that blue penciling would introduce too inuch uncertainty into the licensing process. However, there inay be a few restrictions that are so inhibiting of innovation that they should be considered per se unlawful (a ban on reverse engineering may be one). Pointing these out in the draft would be especially helpful to parties who otherwise might bargam over provisions that cannot later be enforced.

343. See, e.g., Reed, Roberts Assocs., Inc. v. Strauman, 353 N.E.2d 590, 593 (N.Y. 1976); Allis-Chalmers Mfg. Co. v. Continental Aviation \& Eng'g Corp., 255 F. Supp. 645, 654 (E.D. Mich. 1966).

344. See, e.g., U.C.C. \$§ 2B-110, 2B-208(a), 2B-626(c), 2B-703(d) (Annual Meeting Draft, July 24-31, 1998).

345. See Robert P. Merges, Intellectual Property and the Cost of Commercial Exchange: A Review Essay, 93 Mich. L. REv. 1570, 1613 (1995) (suggesting that when a practice becomes uniform in an industry, contracts are essentially converted into private legislation). 
Further, the drafters could provide safe harbors and, as discussed further below, promulgate guidelines on tough issues, such as permissible limitations on fair use and first sale. Endorsing this approach might, in the end, have more of an in terrorem effect than a direct impact, with licensors restraining themselves in order to avoid judicial scrutiny of the terms of their agreements.

\section{Take Limited Times Seriously}

Although the Constitution's Limited Times provision is addressed only to Congress, ${ }^{346}$ many of the most worrisome features of Article $2 \mathrm{~B}$ would be minimized if contract rights were certain to terminate in the way that patents and copyrights do. Material would eventually become public, licensing would not become so much more desirable than sell$\mathrm{mg}$, and trade secrets would never be as valuable as patent rights.

Section 2B-308 contemplates a limit on the duration of indefinite agreements. For licenses of federal rights, it quite rightly incorporates the terms of "other law." ${ }^{347}$ For other agreements, however, the duration is determined by what is "reasonable in light of the commercial circumstances." ${ }^{2348}$ The discussion here should make it clear that commercial circumstances-presumably including the ability of a company like ProCD to earn an adequate return on investment-is a necessary referent, but it may not be sufficient. Courts should also consider what is reasonable from the perspective of innovation.

In fact, state courts have had some experience with the problem of perpetuating trade secrets. In the context of remedies, they have shown increasing willingness to reject applications for permanent injunctions and to opt mstead for relief that extends only for so long as the information would have remamed secret. ${ }^{349} \mathrm{~A}$ similar analysis could be used here. Moreover, the reasonableness inquiry should be extended to contracts that are of defimite, but long, duration.

\section{Consider the Baseline}

The mam critique of the rights distinction is that it fails to consider the cumulative effects of bilateral contracts. As a result, it would permit licensing even when the net effect of licensors' practices is to take the

346. See U.S. ConST. art. I, § 8.

347. U.C.C. $\$ 2 B-308$ (Annual Meeting Draft, July 24-31, 1998).

348. Id.

349. Compare Lamb-Weston, Inc. v. McCain Foods, Ltd., 941 F.2d 970, 974 (9th Cir. 1991) (calculating the time it would have taken to acquire the information by proper means, that is, by reverse engineering the plaintiff's product) with Shellmar Prods. Co. v. Allen-Quallcy Co., 87 F.2d 104 (7th Cir. 1936) (enforcing permanent injunction despite public knowledge of information). The Restatement (Third) of Unfair Competition also endorses the limited approach. See RESTATEMENT (THIRD) OF UNFAIR COMPETITION $\$ 44$ cint. $\mathrm{f}$ (1995). 
licensed technology beyond all reach of the creative community. But not all licenses have that effect, and courts should be encouraged to consider how a particular agreement departs from the baseline of free competition emphasized in Bonito Boats. ${ }^{350}$ In that case, the use restriction was in a statute, which bound everyone withm Florida's legislative jurisdiction. Thus, it departed very substantially froin that baseline, and the Court never reached the question of how far a rights holder could go without frustrating federal policy. If what I suggest is right, then it behooves the drafters (and the courts) to develop ways of thinking about just how much leeway there actually exists. ${ }^{351}$

First, there should be some consideration of who is bound. When a particular restriction is not in a inass market contract, and binds only individual licensees so that the rest of the world is truly free to use the technology (as in the Quick Point ${ }^{352}$ case), the restriction should be considered permissible. Where no one can duplicate the licensor's work at anything approaching the licensor's cost (as in the Feist ${ }^{353}$ case), then exclusivity is a real concern. Between these extremes is a line that will admittedly be hard to draw, especially in light of the need for empirical evidence on cost. It would be quite useful, therefore, if the draft provided a series of examples of permissible deviations froin the baseline. (Because they involve purchasers of varying degrees of sophistication and information of varying degrees of accessibility, the contracts of Westlaw, of Nexis, and in ProCD would all inake good examples.)

Next, the innovator/licensor's position should be considered. Some innovators enjoy lead time and federal rights that allow them to reap substantial benefits from their innovations quite apart from challenged restrictions; others can look only to their contracts for a return on their investment. In the latter case, the benefits of providing innovators with a sure incoine stream may outweigh the social costs of exclusivity. Since this consideration means that federal rights holders are not always in the same position as trade secret holders, federal limits on patent and

350. See Bonito Boats, Inc. v. Thunder Craft Boats, Inc., 489 U.S. 141, 156 (1989).

351. To be sure, the Bonito Boats Court seemed incensed that the statite frustrated the "most efficient nuanner" for reproducing a boat hull, id. at 158, but the decision did not turn on that finding, and the Court has been criticized for that remark. See Paul Heald, Federal Intellectual Property Law and the Economics of Preemption, 76 Iowa L. Rev. 959, 985 (1991); John Shepard Wiley, Jr., Bonito Boats: Uninformed but Mandatory Innovation Policy, 1989 SuP. CT. REv. 283, 287.

352. Aronson v. Quick Point Pencil Co., 440 U.S. 257 (1979).

353. Feist Publications, Inc. v. Rural Telephone Serv. Co., 499 U.S. 340 (1991). In Feist, the plaintiff collected the information at issue as a byproduct of offering telephone service; anyone else who sougbt to gather the same information would have had to make a door-to-door inquiry. See id. at 343. 
copyright licenses should not be applied to licenses of nonfederal rights too reflexively. ${ }^{354}$

\section{Reconsider Digital and Like Environments}

One of the most intriguing new ideas in this area coines from Robert Merges, who has argued that the traditional differentiation between property and contract rights becoines less relevant on-line. In his view, property rights are off-the-shelf legal relationships that are inportant only when transaction costs are too high to nake customized contracts feasible. Because the on-line environment reduces the costs of negotiating, there is less need to worry about property rights or, more accurately, about their associated doctrines. So long as it is easy to obtain the necessary permissions, restrictions on use-including restrictions on fair use-are tolerable. ${ }^{355}$

This theory obviously is limited somewhat. As Merges notes, lowering transaction costs requires that issues of ownership and scope be clearly resolved. ${ }^{356}$ Even he admits that some preemption analysis will remain necessary. ${ }^{357}$ The basic principle, however, is right. In considering the reasonableness of a particular limitation, courts should consider not only its impact on innovation, but also the would-be innovator's ability to enter imto alternative transactions for similar infornation. The theory may also apply more broadly, not only to on-line transactions. Clearinghouses are also effective at lowering the costs of negotiation. ${ }^{358}$ In fields like biotechnology, transaction costs may also be lower because innovation occurs in coinplex networks, allowing participants to know one another well. ${ }^{359}$

\section{Piggyback on the Federal Trade Commission}

As noted above, the upshot of deciding that restraints are not per se unlawful is not a finding that they are per se lawful. In the Antitrust Guidelines for the Licensing of Intellectual Property, ${ }^{360}$ the Antitrust

354. Unfortunately, the drafters do this themselves, as I note in my discussion of their treatment of Everex. See supra text accompanying notes 158-164.

355. See Robert P. Merges, The End of Friction? Property Rights in the "Newtonian" World of On-Line Commerce, 12 BERKELEY TECH. L.J. 115, 130-32 (1997); see also Frank H. Easterbrook, Cyberspace and the Law of the Horse, 1996 U. CHI. LEGAL F. 207, 208-12.

356. See Merges, supra note 355, at 119.

357. See id. at 126.

358. See Easterbrook, supra note 355, at 213-15. Like Merges, Judge Easterbrook does not appear to believe that costs can ever be reduced enough to dispense with public-regarding doctrines.

359. See Powell, supra note 99, at 211; Paul L. Robertson \& Richard N. Langlois, Innovation, Networks, and Vertical Integration, 24 RESEARCH POL'Y 543, 547-52 (1995).

360. See U.S. Dep't of Justice \& Federal Trade Comm'n, Antitrust Guidelines for THE Licensing of INTEllectual Property (1995), reprinted in 4 Trade Reg. Rep. (CCH) I 13,132 (1995). As to misuse, however, some courts still take a per se approach. See, e.g., Meehan v. PPG Indus., 802 F.2d 881, 886 (7th Cir. 1986). 
Division of the Department of Justice and the Federal Trade Commission have adopted a rule-of-reason approach for determining when intellectual property licenses raise competitive concerns. These guidelines are mainly intended to help courts examine the effects of licenses on the competitive market, but the Commission in particular has also done a great deal of thinking about the effects of various arrangeinents on innovation markets. ${ }^{361}$ Its work tends to look at the relatively short term, but the attention it has paid to the structure of the research and development industry adds an important ingredient to the analysis. Although courts should be slow to apply thinking about patents and copyright directly to nonfederally protected works, the guidelimes are one of the few places where innovation policy as a whole has been considered carefully. The rules promulgated in the guidelines could be helpful to judges struggling to inake sense of preemption doctrine and normative policies. Even better, they could form the basis for the commentary. The guidelines also provide safe harbors which would be most welcome in the context of Article $2 \mathrm{~B}$.

\section{CONCLUSION}

The drafters of Article 2B were on target about many things. They were certainly right about the need to construct a method for transacting in an on-line environment. They were quite right about the need to pull computer technology out of Article 2 . They were also quite right that intangibles are, by their nature, different from goods, and that if a new statute was to be written for software, the licensing of other intangibles should be treated at the same time. If one of the drafters' unstated goals was to create a mechamism for rewarding the developers of subpatentable and subcopyrightable materials, that was probably right as well. (More accurately, they are right so long as these matters are not resolved legislatively.) Article $2 \mathrm{~B}$ is a tremendous contribution to the law on these issues, although there are several places where the drafters' important insights on the nature of information were effectuated imperfectly.

Where the drafters really went wrong was in not paying more attention to upstream issues. Exclusive rights have an mevitable impact on creativity, and the more closely they can be controlled, the more they can interfere with the ability of future innovators to push the frontiers of

361. See U.S. Dep't of Justice \& Federal Trade COMm'N, supra note 360 , $\$ 3.2 .3$ ("An innovation market consists of the research and development directed to particular new or improved goods or processes, and the close substitutes for that research and development."). See also FEDERAL Trade Comm'n, Anticipating the 21st Century: Competition Policy in the New HighTech, Global Marketplace (1996), especially chapter 7, "Innovation and the Assessment of Competitive Effects," and chaptcr 8, "Intellectual Property and Antitrust Policy for New Technologies." 
knowledge forward. The drafters seem to have adopted the view that what is good for Microsoft is good for America. That might be true of Article 2 and goods, of cars and General Motors, but it is not true here. A robustly innovative community requires a sure return on its investment-the drafters are right there-but it also requires a rich public domain. To be sure, Article $2 \mathrm{~B}$ states that provisions inconsistent with federal law should not be enforced. But Article 2B fails to provide guidance on deciding when there are inconsistencies, and it leaves open questions about the application of state innovation policy that preexisted its adoption. As the July 1998 Annual Meeting Draft now reads, it is both a trap to unwary licensors, who might bargain for restrictions that they cannot later enforce, and a trick on unsophisticated licensees, who might regard themselves as limited by provisions that frustrate their creativity in a manner that is inconsistent with national policy. 